FACULDADE DE FILOSOFIA, LETRAS E CIÊNCIAS HUMANAS DEPARTAMENTO DE CIÊNCIA POLÍTICA

PROGRAMA DE PÓS-GRADUAÇÃO EM CIÊNCIA POLÍTICA

\title{
AGENDA-SETTING \\ E A ELEIÇÃO PRESIDENCIAL DE 2002 NO BRASIL
}

Paulo Sérgio da Silva

Tese apresentada ao Programa de PósGraduação em Ciência Política, da Faculdade de Filosofia, Letras e Ciências Humanas, para a obtenção do título de doutor em Ciência Política

Orientadora: Profa. Dra. Maria D'Alva G. Kinzo

São Paulo

2005 


\section{UNIVERSIDADE DE SÃO PAULO \\ FACULDADE DE FILOSOFIA, LETRAS E CIÊNCIAS HUMANAS DEPARTAMENTO DE CIÊNCIA POLÍTICA \\ PROGRAMA DE PÓS-GRADUAÇÃO EM CIÊNCIA POLÍTICA}

\section{AGENDA-SETTING \\ E A ELEIÇÃO PRESIDENCIAL DE 2002 NO BRASIL}

Paulo Sérgio da Silva

São Paulo

2005 


\section{Agradecimentos}

Muitas pessoas me ajudaram durante o longo período que passei pesquisando e escrevendo sobre esse assunto. Em primeiro lugar, quero agradecer à Maria D'Alva Gil Kinzo, pela seriedade intelectual e dedicação que orientou o meu trabalho.

A Orjan Olsen, gostaria de fazer um agradecimento especial, não só em virtude da ajuda concedida a este estudo, mas principalmente pela confiança que me infundiu e pelo estímulo intelectual que me tem transmitido.

Também agradeço os comentários e indicações bibliográficas de Leandro Piquet, Rogério Schmitt, Fernando Azevedo, Mauro Porto, Vinício de Lima, Leandro Colling, Luis Felipe Miguel, Alessandra Aldé, Yan de Souza Carreirão, Maria do Socorro Braga e Vera Chaia.

Minha gratidão também se estende a meus amigos Luiz Cláudio Lourenço, Craig H. Francis, José Paulo Júnior, Simone Bohn, Raiane Severiano, Thiago Borges, Hilton Cezário, Celso Roma, Marcio Antônio Jesus Lopes, Ludmila Alves, Jairo Pimentel, Ivan Borin, Ana Carolina e Sérgio Praça; à Amanda agradeço a ajuda nas gravações da propaganda e dos telejornais.

Finalmente, quero agradecer à Coordenadoria de Aperfeiçoamento de Pessoal e Ensino Superior (CAPES), cujo apoio financeiro possibilitou-me despender quatro anos de estudo na Universidade de São Paulo.

Embora este trabalho tenha contado com a contribuição de várias pessoas, convém lembrar que a responsabilidade pelos erros, defeitos e insuficiências cabe apenas ao autor. 


\section{Sumário}

Agradecimentos 3

Resumo $\quad 5$

Abstract $\quad 6$

Índice de Tabelas $\quad 7$

Índice de Gráficos $\quad 10$

Índice de Quadros e Figuras $\quad 11$

$\begin{array}{ll}\text { Introdução } & 12\end{array}$

Capítulo 1 Marco teórico e modelo de análise 20

1.1 Introdução 20

1.2 As origens da agenda-setting 20

1.3 Referencial teórico $\quad 26$

1.4 Estudos empíricos 33

1.5 Modelo de análise, hipóteses e metodologia 36

1.6 Conclusões 43

Capítulo 2 Contexto da eleição presidencial de 2002

2.1 Introdução $\quad 45$

2.2 Aspecto da conjuntura sócio-econômica 45

2.3 Alianças partidárias 49

2.4 Campanha nos meios de comunicação $\quad 52$

2.5 Conclusões $\quad 60$

Capítulo 3 Conteúdo das agendas em jogo 62

3.1 Introdução $\quad 62$

3.2 Programas de governo 63

3.3 Propaganda de Lula e de Serra na televisão 70

3.4 Cobertura de Lula e de Serra nos telejornais 82

3.5 Conclusões 93

Capítulo 4 Agenda-setting da campanha de $2002 \quad 95$

4.1 Introdução $\quad 95$

4.2 Programa do PT e propaganda de Lula na televisão 95

4.3 Associação entre propaganda de televisão e cobertura dos noticiários 100

4.4 Cross-lagged correlations 111

4.5 Conclusões 130

$\begin{array}{ll}\text { Considerações finais } & 132\end{array}$

$\begin{array}{lr}\text { Bibliografia } & 140\end{array}$

$\begin{array}{ll}\text { Anexos } & 146\end{array}$ 


\section{Resumo}

Enquanto os estudos internacionais têm demonstrado uma grande preocupação em pesquisar a capacidade dos candidatos de influenciar a formação da agenda dos meios de comunicação de massa em épocas eleitorais, no Brasil a agenda das candidaturas não foi incorporada aos trabalhos acadêmicos de mídia e eleições. Neste estudo tive como objetivo avaliar a importância da agenda da propaganda dos candidatos para a formação da agenda da cobertura dos telejornais na eleição presidencial de 2002, bem como a relevância do programa de governo do PT para a elaboração da agenda da propaganda de seu candidato, Luiz Inácio Lula da Silva, nessa mesma eleição. Os dados mostraram que as candidaturas Lula e Serra conseguiram transferir para suas coberturas eleitorais do Jornal Nacional e Jornal da Record a ênfase dos assuntos discutidos em suas propagandas de televisão. Demonstraram também que o PT obteve êxito em transmitir para a propaganda de televisão da candidatura Lula a saliência da pauta discutida em sua plataforma. Com base nesses resultados, conclui que os candidatos influenciaram a agenda dos telejornais e que o PT, em particular, também cumpriu a função de agenda-setting, agendando os assuntos da propaganda da candidatura Lula na televisão.

Palavras-chave:

agenda-setting; eleição; partido político; propaganda eleitoral; mídia 


\begin{abstract}
While the international studies have shown a great concern with the study of the candidate's capacity to influence the formation of the mass media agenda during the electoral campaign period, in Brazil, the candidate's agenda has not been included in the academic studies of media and elections. In this study, my objective was to evaluate the candidates' importance for the formation of the TV news coverage agenda on the presidential election in 2002, as well as the relevance of the PT for the elaboration of the advertising his candidate, Luiz Inácio Lula da Silva, in that same election. The data showed that both Lula and Serra succeeded in transferring to their electoral coverings of the "Jornal Nacional" and "Jornal da Record" the themes and issues discussed in their TV ads. The data also showed that the PT had success in transmitting to Lula's TV ads the salient themes presented by the party's program. The evidence I provided allowed me to conclude that the candidates influenced the new's agenda and that the PT, in particular, also fulfilled the function of agenda setting, by effectively influencing the content of its candidate's campaign on TV.
\end{abstract}

\title{
Key words
}

agenda-setting; election; political party; political advertising; mass media 


\section{ÍNDICE DE TABELAS}

TABELA 3.1 - Assuntos substantivos do programa de governo do PT - em porcentagem

TABELA 3.2 - Assuntos substantivos do programa de governo de Serra - em porcentagem

TABELA 3.3 - Assuntos da propaganda de Lula na televisão $\left(1^{\circ}\right.$. e $2^{\circ}$. turnos da eleição presidencial de 2002$)$ - em porcentagem

TABELA 3.4 - Assuntos da propaganda de Serra na televisão $\left(1^{\circ}\right.$. e $2^{\circ}$. turnos da eleição presidencial de 2002) - em porcentagem

TABELA 3.5 - Assuntos da cobertura eleitoral de Lula nos telejornais, Jornal Nacional e Jornal da Record $\left(1^{\circ}\right.$. e $2^{\circ}$. turnos da eleição presidencial de 2002) - em porcentagem

TABELA 3.6 - Assuntos da cobertura de Serra nos telejornais, Jornal Nacional e Jornal da Record $\left(1^{\circ}\right.$. e $2^{\circ}$. turnos da eleição presidencial de 2002) - em porcentagem

TABELA 3.7 - Cobertura eleitoral de Lula e Serra nos telejornais Jornal Nacional e Jornal da Record, de acordo com a classificação de Patterson (1980) - $1^{\circ}$. e $2^{\circ}$. turnos da eleição presidencial de 2002

TABELA 4.1 - Assuntos substantivos do programa de governo do PT e da propaganda eleitoral de Lula na tevê $-1^{\circ}$. e $2^{\circ}$. turnos da eleição presidencial de 2002 (13 assuntos)

TABELA 4.2 - Todos os assuntos da propaganda de Lula na televisão e da cobertura eleitoral de Lula nos telejornais, Jornal Nacional e Jornal da Record $-1^{\circ}$. e $2^{\circ}$. turnos da eleição presidencial de 2002 (20 assuntos)

TABELA 4.3 - Assuntos substantivos da propaganda de Lula na televisão e da cobertura eleitoral de Lula nos telejornais, Jornal Nacional e Jornal da Record $-1^{\circ}$. e $2^{\circ}$. turnos da eleição presidencial de 2002 (13 assuntos)

TABELA 4.4 - Assuntos restantes da propaganda eleitoral de Lula na televisão e da cobertura eleitoral de Lula nos telejornais, Jornal Nacional e Jornal da Record $-1^{\circ}$. e $2^{\circ}$. turnos da eleição presidencial de 2002 (7 assuntos) 
TABELA 4.5 - Todos os assuntos da propaganda de Serra na televisão e da cobertura eleitoral de Serra nos telejornais, Jornal Nacional e Jornal da Record $-1^{\circ}$. e $2^{\circ}$. turnos da eleição presidencial de 2002 (19 assuntos)

TABELA 4.6- Assuntos substantivos da propaganda de Serra na televisão e da cobertura eleitoral de Serra nos telejornais, Jornal Nacional e Jornal da Record $-1^{\circ}$. e $2^{\circ}$. turnos da eleição presidencial de 2002 (13 assuntos)

TABELA 4.7 - Assuntos restantes da propaganda eleitoral de Serra na televisão e da cobertura eleitoral de Serra nos telejornais, Jornal Nacional e Jornal da Record $-1^{\circ}$. e $2^{\circ}$. turnos da eleição presidencial de 2002 (6 assuntos)

TABELA 4.8 - 24 correlações para a verificação da transferência das prioridades de todos os assuntos da propaganda de Lula para a agenda de todos os assuntos da cobertura eleitoral de Lula nos telejornais (Jornal Nacional e Jornal da Record) - $1^{\circ}$. e $2^{\circ}$. turnos da eleição presidencial de 2002

TABELA 4.9 - 20 correlações para a verificação da transferência das prioridades dos assuntos substantivos da propaganda de Lula para a agenda dos assuntos substantivos da agenda da cobertura eleitoral de Lula nos telejornais (Jornal Nacional e Jornal da Record) $1^{\circ}$. e $2^{\circ}$. turnos da eleição presidencial de 2002

TABELA 4.10 - 20 correlações para a verificação da transferência das prioridades dos assuntos restantes da propaganda de Lula para a agenda dos assuntos restantes da cobertura eleitoral de Lula nos telejornais (Jornal Nacional e Jornal da Record) $1^{\circ}$. e $2^{\circ}$. turnos da eleição presidencial de 2002

TABELA 4.11 - 24 correlações para a verificação da transferência das prioridades de todos assuntos da cobertura eleitoral de Lula nos telejornais (Jornal Nacional e Jornal da Record) para a agenda de todos os assuntos da propaganda de Lula na televisão $-1^{\circ}$. e $2^{\circ}$. turnos da eleição presidencial de 2002

TABELA 4.12 - 20 correlações para a verificação da transferência das prioridades dos assuntos substantivos da cobertura eleitoral de Lula nos telejornais (Jornal Nacional e Jornal da Record) para a agenda dos assuntos dos substantivos da propaganda de Lula $-1^{\circ}$. e $2^{\circ}$. turnos da eleição presidencial de 2002 
TABELA 4.13 -24 correlações para a verificação da transferência de todos os assuntos da propaganda de Serra para a agenda de todos os assuntos da cobertura eleitoral de Serra nos telejornais (Jornal Nacional e Jornal da Record) - $1^{\circ}$. e $2^{\circ}$. turnos da eleição presidencial de 2002

TABELA 4.14 -20 correlações para a verificação da transferência das prioridades dos assuntos substantivos da propaganda de Serra para a agenda dos assuntos substantivos da agenda da cobertura eleitoral de Serra nos telejornais (Jornal Nacional e Jornal da Record) $1^{\circ}$. e $2^{\circ}$. turnos da eleição presidencial de 2002

TABELA 4.15 - 20 correlações para a verificação da transferência das prioridades dos assuntos restantes da propaganda de Serra para a agenda dos assuntos restantes da cobertura eleitoral de Serra nos telejornais (Jornal Nacional e Jornal da Record) $1^{\circ}$. e $2^{\circ}$. turnos da eleição presidencial de 2002

TABELA 4.16 - 24 correlações para a verificação da transferência de todos assuntos da cobertura eleitoral de Serra nos telejornais (Jornal Nacional e Jornal da Record) para a agenda de todos os assuntos da propaganda de Serra na tevê $-1^{\circ}$. e $2^{\circ}$. turnos da eleição presidencial de 2002

TABELA 4.17 - 20 correlações para a verificação da transferência das prioridades dos assuntos substantivos da cobertura de Serra nos telejornais (Jornal Nacional e Jornal da Record) para a agenda dos assuntos restantes da propaganda eleitoral de Serra $1^{\circ}$. e $2^{\circ}$. turnos da eleição presidencial de 2002 


\section{ÍNDICE DE GRÁFICOS}

GRÁFICO 2.1- Intenção de voto para presidente - eleição presidencial de 2002

GRÁFICO 2.2 - Intenção de voto em Lula no período de março a maio de 2002

GRÁFICO 2.3 - Variação do risco Brasil no período de março a maio de 2002

GRÁFICO 2.4 - Intenção de voto para Presidente - primeiro turno da eleição presidencial de 2002

GRÁFICO 2.5 - Intenção de voto para presidente - segundo turno da eleição presidencial de 2002

GRÁFICO 3.1 - Cobertura de Lula e Serra nos telejornais (Jornal Nacional e Jornal da Record), de acordo com a classificação de Patterson (1980) $-1^{\circ}$. e $2^{\circ}$. turnos da eleição presidencial de 2002

GRÁFICO 4.1 - Gráfico da correlação dos assuntos do programa de governo do PT e da propaganda de Lula na televisão

GRÁFICO 4.2 - Gráfico da correlação de todos os assuntos da propaganda de Lula e da cobertura de Lula nos telejornais

GRÁFICO 4.3 - Gráfico da correlação dos assuntos substantivos da propaganda de Lula e da cobertura de Lula nos telejornais

GRÁFICO 4.4 - Gráfico da correlação das ordens dos assuntos restantes da propaganda de Lula e da cobertura de Lula nos telejornais

GRÁFICO 4.5 - Gráfico da correlação de todos os assuntos da propaganda de Serra e da cobertura de Serra nos telejornais

GRÁFICO 4.6 - Gráfico da correlação dos assuntos substantivos da propaganda de Serra e da cobertura de Serra nos telejornais

GRÁFICO 4.7 - Gráfico da correlação dos assuntos restantes da propaganda de Serra e cobertura de Serra nos telejornais 


\section{ÍNDICE DE QUADROS E FIGURAS}

QUADRO 1.1 - Modelo (cross-lagged correlation) utilizado por McCombs e Shaw no estudo da influência da agenda da mídia na agenda do público, durante a campanha presidencial de 1968 nos Estados Unidos, na cidade de Chapel Hill, Carolina do Norte

QUADRO 1.2- Papel da agenda-setting dos meios de comunicação de massa

QUADRO 1.3 - Expansão da teoria da agenda-setting

QUADRO 1.4 - "Metáfora da cebola" da agenda-setting da mídia

QUADRO 1.5 - Modelo (Cross-lagged correlation) utilizado para a verificação da transferência do conteúdo da propaganda dos candidatos para o conteúdo da cobertura eleitoral de Lula e Serra nos telejornais (Jornal Nacional e Jornal da Record) na eleição presidencial de 2002

FIGURA 1.1 - Esquema do processo da agenda-setting da eleição presidencial de 2002 em análise

FIGURA 1.2 - Processo da agenda-setting da candidatura Lula na televisão

FIGURA 1.3 - Processo da agenda-setting da candidatura Serra na televisão

FIGURA C.1 - Cross-lagged correlations - síntese dos resultados (Lula)

FIGURA C. 2 - Cross-lagged correlations - síntese dos resultados (Serra) 


\section{Introdução}

Assim como em disputas presidenciais anteriores no atual multipartidarismo brasileiro, a eleição de 2002 teve a televisão como principal meio de divulgação da campanha dos candidatos. O horário eleitoral ${ }^{1}$ veiculado durante a programação normal das emissoras desempenhou um papel basilar para a divulgação das candidaturas, já que serviu a essas como um valioso canal de difusão das plataformas e imagens pessoais. A cobertura eleitoral realizada pelos mais importantes telejornais do país, Jornal Nacional e Jornal da Record, exerceu uma função complementar às candidaturas, posto que mediou o contato diário dos políticos com os eleitores no horário nobre da televisão brasileira.

Diante desse quadro, chama atenção o fato de serem os candidatos, através da propaganda de televisão, e os jornalistas, por meio da cobertura das candidaturas nos noticiários, os dois principais atores responsáveis pela elaboração da agenda dos assuntos divulgados ao público durante as campanhas eleitorais no Brasil.

Sendo esse o caso, tornam-se válidas as seguintes indagações: há alguma conexão entre a agenda dos candidatos e a agenda dos jornalistas de televisão, ou elas são independentes? Os candidatos são hábeis em transferir suas preferências temáticas, veiculadas em suas propagandas, para a pauta diária dos profissionais da mídia televisiva? Ou são os jornalistas que influenciam a agenda dos candidatos?

\footnotetext{
${ }^{1}$ O horário eleitoral é particularmente o formato tradicional da propaganda política de televisão no Brasil, sendo sua data de criação 22 de agosto de 1962 pela lei 4.115. A intervenção do regime militar na legislação eleitoral aconteceu através da lei 6.339 de $1^{\circ}$. de julho de 1976 , conhecida como "Lei Falcão". Conforme esta lei, as regras da propaganda política de televisão foram modificadas, exigindo-se somente a apresentação do nome, número e fotografia do candidato, além de informar o local e o horário dos comícios. Depois de 1985 o horário eleitoral ficou livre das amarras da censura. Na eleição presidencial de 1994, as regras eleitorais foram modificadas, sendo estabelecidos limites rígidos para o conteúdo da propaganda, além da proibição do uso de montagens e trucagens, cenas externas ao estúdio e a presença de outras pessoas que não a do candidato no vídeo. Nas eleições municipais de 1996 estas regras desapareceram e o conteúdo do horário eleitoral ficou livre novamente para a criação de
} 
No que se refere especificamente à agenda dos candidatos, é importante saber em que medida os partidos políticos influenciam a elaboração das agendas de suas candidaturas na propaganda de televisão por meio das plataformas eleitorais. É verdade que geralmente os programas de governo apresentados em eleições presidenciais são elaborados pelos candidatos e suas equipes de campanha e não passam pela discussão e aprovação da base partidária, como foi o caso do programa de governo de Serra na eleição presidencial de 2002. Mas no caso do PT, a situação é diferente. O programa de governo é debatido pela base antes de ser direcionado à campanha eleitoral, como ocorreu no pleito de 2002. Desse modo a seguinte questão é válida: será que o PT, através de seu programa de governo, não é capaz de agendar a agenda da propaganda de televisão de seu candidato? Qual a influência da plataforma deste partido na agenda da campanha eleitoral de sua candidatura?

Ao contrário do que se observa na bibliografia internacional, na qual os "novos" estudos da agenda-setting têm mostrado uma ampla capacidade dos candidatos de agendar a agenda da mídia em campanhas eleitorais, a maior parte da literatura produzida no Brasil não tem incorporado, nas análises das campanhas presidenciais, a agenda dos políticos como uma variável que pode influenciar a construção da agenda dos meios de comunicação. De maneira geral, observa-se profunda influência gramsciana ${ }^{2}$ nas análises sobre as coberturas eleitorais dos telejornais, como é o caso dos trabalhos que adotam a perspectiva dos Cenários de Representação Política ${ }^{3}$ (CR-P). Tal influência tem contribuído para superestimar o papel dos noticiários de televisão, principalmente do Jornal Nacional, na elaboração da agenda das campanhas eleitorais brasileiras. A seguir, comento alguns estudos nacionais de mídia e eleições com o intuito de ressaltar a escassez de trabalhos que tiveram como

estratégias distintas de persuasão política. Sobre a legislação da propaganda eleitoral de televisão e rádio no Brasil, ver LIMA, 1994b.

${ }^{2}$ Refiro-me ao conceito de hegemonia cultura de Gramsci.

${ }^{3}$ Segundo RUBIM \& AZEVEDO (1998: 200), no Brasil as teses gramscianas da hegemonia mantêm vigência em uma diversidade de estudos, por vezes de modo quase puro, por vezes mitigadas com formulações posteriores, como cultural studies - cujos autores Raymond Williams e Stuart Hall receberam forte influência do próprio pensamento de Gramsci . 
foco de análise as relações entre a agenda dos candidatos e agenda da mídia na formação da agenda das campanhas.

A maioria dos estudos sobre coberturas dos telejornais em eleições desconsidera a possível influência de outras agendas, como a dos candidatos ou da propaganda de televisão, na construção da agenda dos jornalistas. Estes estudos podem ser divididos em quatro grupos:

1) aquelas análises das coberturas de eleições presidenciais no Jornal Nacional que adotam a teoria dos CR-Ps (Lima, 1990; Porto, 1995; Fabrício e Maciel, 1995; Lima e Guazina, 1998; Colling, 1999; Miguel, 1999);

2) os trabalhos que fazem o levantamento da agenda da cobertura eleitoral dos noticiários de televisão, utilizando como escopo teórico a teoria "clássica" da agenda-setting 4 (Albuquerque, 1994; Azevedo, 2000; Chaia, 2002);

3) os estudos voltados para a avaliação da "imparcialidade" ou "parcialidade" da mídia (Figueiredo, 1997; Azevedo, 2001; Aldé, 2002; Miguel, 2003; Silva, 2003);

4) e, por fim, as investigações que adotam a perspectiva dos enquadramentos ${ }^{5}$ para a análise das notícias de televisão (Porto, 2001; Porto, 2004).

Os trabalhos do primeiro grupo entendem que os meios de comunicação, em particular a Rede Globo de Televisão, desempenham a função de vigilância ideológica junto à sociedade. De acordo com tais

\footnotetext{
${ }^{4}$ A agenda-setting, modelo teórico surgido na década de 70 , defende a idéia de que a mídia é capaz de estabelecer um conjunto de questões a serem discutidas pelo público. A atribuição "clássica" é porque, na fase originária da agenda-setting não se questionava o agendamento da agenda da mídia. Isto será discutido no primeiro capítulo deste trabalho.

${ }^{5}$ De acordo com Entman, o enquadramento define problemas, diagnostica causas, avalia agentes causais e efeitos, oferecendo e justificando tratamentos para os problemas, além de predizer seus efeitos. ENTMAN, 1993, p. 52 et. seq.
} 
trabalhos, não só os telejornais, mas toda a programação da Rede Globo, estariam voltados para a disseminação de determinados conceitos sociais, políticos e econômicos, com o intuito de manter a sociedade subjugada à elite dominante. A mídia é tida como uma fonte de construção de determinados cenários, cuja finalidade seria a reprodução do status quo (Lima, 1994a). Segundo Lima, o CR-P é construído em processos de longo prazo pela mídia, especialmente na televisão. Um candidato teria êxito na eleição se fosse capaz de se ajustar ao CR-P criado pela mídia (Lima, 1994a, p. 10). De acordo com esses estudos, é a mídia quem cria uma agenda de questões e determina a agenda da campanha, desconsiderando-se, portanto, a possível influência da pauta dos políticos na agenda dos jornalistas.

Os estudos do segundo grupo adotam a hipótese "clássica" da agendasetting, admitindo ser a mídia o principal ator que agenda os assuntos para o público em épocas eleitorais. A partir deste enfoque, Albuquerque (1994) realizou um trabalho acerca da cobertura do Jornal Nacional da eleição presidencial de 1994. Azevedo (2000) analisou a agenda de dois jornais, Folha de São Paulo e O Estado de São Paulo, na eleição presidencial de 1998. Chaia (2002) efetuou um estudo sobre a cobertura dos telejornais locais da Rede Globo, Bandeirantes e TV Cultura da eleição para a prefeitura de São Paulo em 2000. Todos estes trabalhos verificaram que é a mídia quem determina a agenda da campanha eleitoral.

Em relação ao terceiro grupo, Figueiredo (1997) efetuou uma comparação entre a cobertura do Jornal Nacional e a cobertura do TJ Brasil da eleição presidencial de 1994. A autora classificou as matérias em positivas, negativas e neutras. A conclusão foi a de que o noticiário da Rede Globo de Televisão fez uma cobertura neutra tanto para Fernando Henrique Cardoso como para Luiz Inácio Lula da Silva, diferentemente do que ocorreu com o TJ Brasil, onde predominou a cobertura negativa a Lula e positiva para FHC. Azevedo (2001) realizou um estudo sobre a cobertura de dois jornais locais de São Paulo durante o período da campanha municipal de 2000 , concluindo que os jornais observados buscaram fazer suas coberturas de acordo com valores da objetividade jornalística, dando o mesmo espaço às principais candidaturas 
em disputa. Aldé (2002) comparou as coberturas da eleição presidencial de 2002 realizadas por quatro jornais, O Estado de São Paulo, Folha de São Paulo, O Globo e Jornal do Brasil. A autora concluiu que a cobertura do Estado de São Paulo foi favorável a Serra; a da Folha e Jornal do Brasil neutra; e a do O Globo regular, favorecendo ora uma candidatura, ora outra. Outro trabalho é o de Miguel (2003), que investigou a cobertura do Jornal Nacional na campanha presidencial brasileira de 2002, através do levantamento da agenda dos temas da cobertura do telejornal, além dos tempos dedicados às candidaturas. O autor concluiu que o telejornal fez uma cobertura eleitoral "imparcial", mediante o tratamento equânime dos candidatos.

No quarto grupo, podemos destacar os trabalhos de Porto (2001; 2004). O primeiro estudo de Porto (2001) teve como objetivo a análise dos enquadramentos da cobertura do jornal Folha de São Paulo sobre a eleição presidencial de 2000 nos Estados Unidos. O autor concluiu que a cobertura deste jornal foi "despolitizada" porque se caracterizou mais pelo enfoque dos assuntos acerca de pesquisas eleitorais e agenda da campanha dos candidatos do que pelo destaque das issues sobre economia, saúde, educação, etc. O segundo estudo de Porto (2004) comparou, a partir da perspectiva dos enquadramentos, o conteúdo das candidaturas Lula, Serra, Ciro e Garotinho do horário eleitoral de televisão com os enquadramentos dessas candidaturas na cobertura do Jornal Nacional durante o primeiro turno da eleição presidencial de 2002. Nesse caso, embora o autor se dedique ao problema das relações entre horário eleitoral e o noticiário global, não toma como referencial teórico os "novos" estudos da agenda-setting, tampouco utiliza, para a comparação da agenda dos candidatos com a agenda do noticiário, as técnicas de praxe dos estudos internacionais acerca desse problema.

$\mathrm{Na}$ literatura sobre a propaganda eleitoral de televisão, três grupos distintos de estudos podem ser destacados:

1) o que se preocupa com os efeitos da legislação na propaganda de televisão (Lima, 1994b; Albuquerque, 1996a; Jorge, 1994); 
2) o grupo de trabalhos que focaliza as estratégias da propaganda eleitoral de televisão (Albuquerque, 1996b; Figueiredo et al., 1998; Lourenço, 2000; Silva, 2000);

3) e aqueles mais centrados nos efeitos produzidos pela propaganda no comportamento dos eleitores (Figueiredo \& Aldé 2004; Lourenço, 2004).

No primeiro grupo, podemos mencionar o trabalho de Lima (1994b), que analisa a legislação eleitoral da propaganda de televisão no Brasil e o estudo de Albuquerque (1996a), que compara o horário eleitoral com os modelos de propaganda política de televisão nos Estados Unidos e da França. O autor também analisa o impacto da lei eleitoral de setembro de 1993 na propaganda da eleição presidencial brasileira de 1994.

No segundo grupo, o trabalho de Albuquerque (1996b) analisa os ataques do candidato Fernando Collor ao adversário Lula, entendendo que na ocasião Collor havia utilizado o horário eleitoral para criar a imagem de "caçador de marajás" e acusar Lula de ameaça aos símbolos nacionais. O estudo de Figueiredo et al. (1998) sobre as campanhas para as prefeituras municipais do Rio de Janeiro e de São Paulo em 1996 busca explicar as estratégias persuasivas dos spots da propaganda eleitoral dessas duas eleições locais. A metodologia desenvolvida por esses autores foi adotada, em seguida, por Lourenço (2000) - em sua análise do horário eleitoral de televisão da eleição para o governo de São Paulo em 1998 - e por Silva (2000), que investigou as estratégias dos candidatos no horário eleitoral de televisão da eleição presidencial de 1998.

O terceiro grupo de estudos sobre a propaganda de televisão refere-se ao exame do impacto do horário eleitoral nos eleitores, bem como da influência dos debates na audiência ${ }^{6}$. Estes trabalhos são desenvolvidos no Laboratório de Pesquisa em Comunicação Política e Opinião Pública (DOXA) do IUPERJ, sob a coordenação de Marcus Figueiredo.

\footnotetext{
${ }^{6}$ Ver trabalho de LOURENÇO, 2004.
} 
Como evidencia este breve levantamento, os estudos nacionais sobre comunicação e política, em sua maioria, não incorporaram na análise o conteúdo da propaganda dos candidatos como uma variável capaz de influenciar a agenda da mídia e em especial a cobertura dos telejornais. Da mesma maneira, não têm se preocupado em investigar a relação entre programa partidário, agenda da propaganda eleitoral e agenda da mídia.

O que proponho neste trabalho é testar a hipótese de que os candidatos conseguiram transferir para o conteúdo das suas coberturas eleitorais nos telejornais, Jornal Nacional e Jornal da Record, a mesma ênfase dos assuntos discutidos no conteúdo de suas propagandas de televisão (horário eleitoral e spots), na eleição presidencial de 2002. Além disso, trato também de testar a hipótese de que o PT, enquanto partido, obteve êxito em transferir para a pauta da propaganda de seu candidato, a mesma ordem da discussão feita em sua plataforma de governo, nessa mesma eleição.

O trabalho está estruturado da seguinte forma. No primeiro capítulo apresentarei a teoria da agenda-setting, referencial teórico da pesquisa em tela. Além disso, descreverei a metodologia do estudo, especificando o modelo analítico construído para a análise do processo da agenda-setting da eleição presidencial de 2002, as hipóteses levantadas na pesquisa, os bancos de dados e as técnicas de análise utilizadas.

No segundo capítulo examinarei alguns fatores contextuais da eleição presidencial de 2002, como a conjuntura sócio-econômica, a articulação das alianças partidárias de sustentação das candidaturas e o contexto da campanha na televisão.

No terceiro capítulo realizarei o levantamento quantitativo, através da análise de conteúdo, dos assuntos da agenda do programa de governo do PT e de José Serra, da propaganda de tevê de Lula e de Serra, além da cobertura dessas duas candidaturas em dois telejornais: Jornal Nacional e Jornal da Record. 
No quarto e último capítulo farei os testes das hipóteses da pesquisa. Primeiramente, realizarei o teste da hipótese de que o PT obteve sucesso em enviar para a agenda da propaganda de Lula na televisão, as prioridades dos assuntos debatidos em sua plataforma partidária. O teste da hipótese de que 0 PSDB conseguiu influenciar a agenda da propaganda de Serra não foi possível de ser efetuado, posto que o programa de governo apresentado na campanha presidencial de 2002 foi elaborado pela candidatura e não pelo partido ${ }^{7}$. Em segundo lugar, realizarei os testes das hipóteses de que os candidatos Lula e Serra foram capazes de transferir para as suas coberturas nos telejornais as prioridades dos assuntos da agenda de suas propagandas de televisão. Por fim, testarei as hipóteses inversas, ou seja, de que foram as coberturas eleitorais de Lula e de Serra, realizadas pelos telejornais, que transmitiram as suas prioridades de assuntos para a agenda da propaganda de Lula e de Serra.

$\mathrm{Na}$ conclusão, farei um resumo dos achados da pesquisa. Destacarei, em especial, a aceitação da hipótese de que as prioridades das agendas das propagandas das candidaturas Lula e Serra foram transmitidas para o conteúdo da cobertura eleitoral dos telejornais, bem como enfatizarei a confirmação da hipótese de que o PT foi capaz de agendar a campanha da propaganda eleitoral de sua candidatura na televisão através de seu programa de governo.

\footnotetext{
7 Sobre este aspecto, Orjan Olsen, da Ipsos Opinion, que participou da elaboração do programa de governo de José Serra na eleição presidencial de 2002, disse, em entrevista, que a plataforma apresentada pelo candidato tucano foi baseada em pesquisas de opinião pública e não foi submetida a qualquer discussão de ordem partidária. Segundo Olsen, a plataforma de Serra foi elaborada visando à propaganda eleitoral de televisão do candidato.
} 
Capítulo 1

\section{Marco teórico e modelo de análise}

\subsection{Introdução}

A preocupação primordial deste capítulo é apresentar o referencial teórico do trabalho, qual seja, a teoria da agenda-setting, além de expor o modelo construído a partir desta perspectiva, para o estudo da campanha presidencial brasileira de 2002. Também é objetivo neste capítulo fazer a apresentação, em detalhes, dos procedimentos metodológicos empregados para a realização da pesquisa.

São quatro as partes que compõem este capítulo. Na primeira, exibo, de maneira sucinta, os fundamentos básicos da fase inicial da teoria da agendasetting, mais voltada para a análise da influência da mídia no público. $\mathrm{Na}$ segunda, exponho o marco teórico de fato deste estudo, isto é, o modelo da formação da agenda da mídia, versão reelaborada da agenda-setting. $\mathrm{Na}$ terceira, delineio alguns trabalhos internacionais que lançaram mão desta perspectiva mais recente para a investigação do impacto da agenda dos políticos na pauta dos meios de comunicação em épocas eleitorais. $\mathrm{Na}$ última parte, apresento o modelo de análise da pesquisa, elaborado a partir da perspectiva da agenda-setting, para o exame da campanha presidencial brasileira de 2002, além de descrever as hipóteses e técnicas utilizadas na pesquisa.

\subsection{As origens da agenda-setting}


São diversas as teorias existentes para explicar a influência que a mídia exerce nos cidadãos em períodos de campanhas eleitorais nas democracias modernas, mas é a perspectiva da agenda-setting a principal delas ${ }^{8}$.

O pressuposto fundamental do paradigma da agenda-setting, em sua fase inicial, é a influência da mídia no público, através do agendamento de temas $^{9}$. Diferentemente de outras teorias existentes, como, por exemplo, a da "agulha hipodérmica" - segunda a qual os meios de comunicação atuam como agulhas, injetando estímulo nas veias dos indivíduos e provocando certas reações previsíveis, em curto espaço de tempo -, a agenda-setting admite que a influência da mídia no público ocorre em um longo espaço de tempo.

Lippman foi quem realizou a primeira investigação a respeito do impacto dos meios de comunicação nas pessoas. Em 1922, o autor observou que as notícias da mídia influenciavam suas audiências ${ }^{10}$. Mais tarde, na década de 60 , Cohen percebeu, através de uma pesquisa, que os meios de comunicação de massa eram muito eficientes em firmar assuntos políticos colocados ao público, fixando temas sobre os quais os eleitores deveriam pensar. A partir dessa constatação, o autor admitiu que a imprensa podia não ter muito sucesso em dizer às pessoas como pensar, mas era muito eficiente em dizer sobre o que pensar ${ }^{11}$.

Embora as investigações acerca da influência da mídia no público já tivessem sido realizadas, foram McCombs e Shaw (1972) que passaram a chamar o processo pelo qual os meios de comunicação agendam as pessoas de agenda-setting, a partir de um estudo da campanha presidencial de 1968

\footnotetext{
${ }^{8}$ Segundo McCombs, hoje são mais de 400 estudos publicados sobre investigações empíricas, em todo o mundo, que adotam a metodologia da agenda-setting. Ver McCOMBS, 2004.

${ }_{9}^{9}$ A bibliografia da Ciência Política relativa ao comportamento eleitoral não se limita aos efeitos dos meios de comunicação no eleitor. Outras perspectivas concorrem com o paradigma da agenda-setting, como a do voto ideológico (Lipset, 1967), a da escolha racional (Dows, 1957), a escola de Michigan (Campbell, 1966) e a escola psicosociológica (Converse, 1964). Para maiores detalhes, consultar SINGER (1999) e CARREIRÃO (2000).

${ }^{10}$ Contrariamente ao estudo de Lippman, Lazarsfeld, através de um estudo da eleição presidencial norte-americana de 1940, na cidade de Erie County, Ohio, encontrou pequena evidência de que os meios de comunicação conseguiam influenciar as atitudes dos eleitores. Ver LAZARSFELD, 1940 e LIPPMAN, 1997.

${ }^{11}$ COHEN, 1963, p. 13.
} 
nos Estados Unidos, na cidade de Chapel Hill, Carolina do Norte ${ }^{12}$. A hipótese central do trabalho foi de que a proeminência da agenda dos meios de comunicação foi transferida para a discussão dos eleitores. Como resultados da pesquisa, os autores encontraram associações significantes entre as questões consideradas mais importantes pelos eleitores e a cobertura dessas issues nas notícias da mídia ${ }^{13}$, levando em conta um intervalo temporal entre a veiculação das notícias e a percepção delas pelo público. No entanto, quando analisaram a influência do conteúdo da agenda do público na agenda da mídia, as associações foram bastante baixas. O modelo cross-lagged correlations utilizado no estudo é apresentado logo abaixo.

QUADRO 1.1 - Modelo (cross-lagged correlation) utilizado por McCombs e Shaw no estudo da influência da agenda da mídia na agenda do público, durante a campanha presidencial de 1968 nos Estados Unidos, na cidade de Chapel Hill, Carolina do Norte ${ }^{14}$

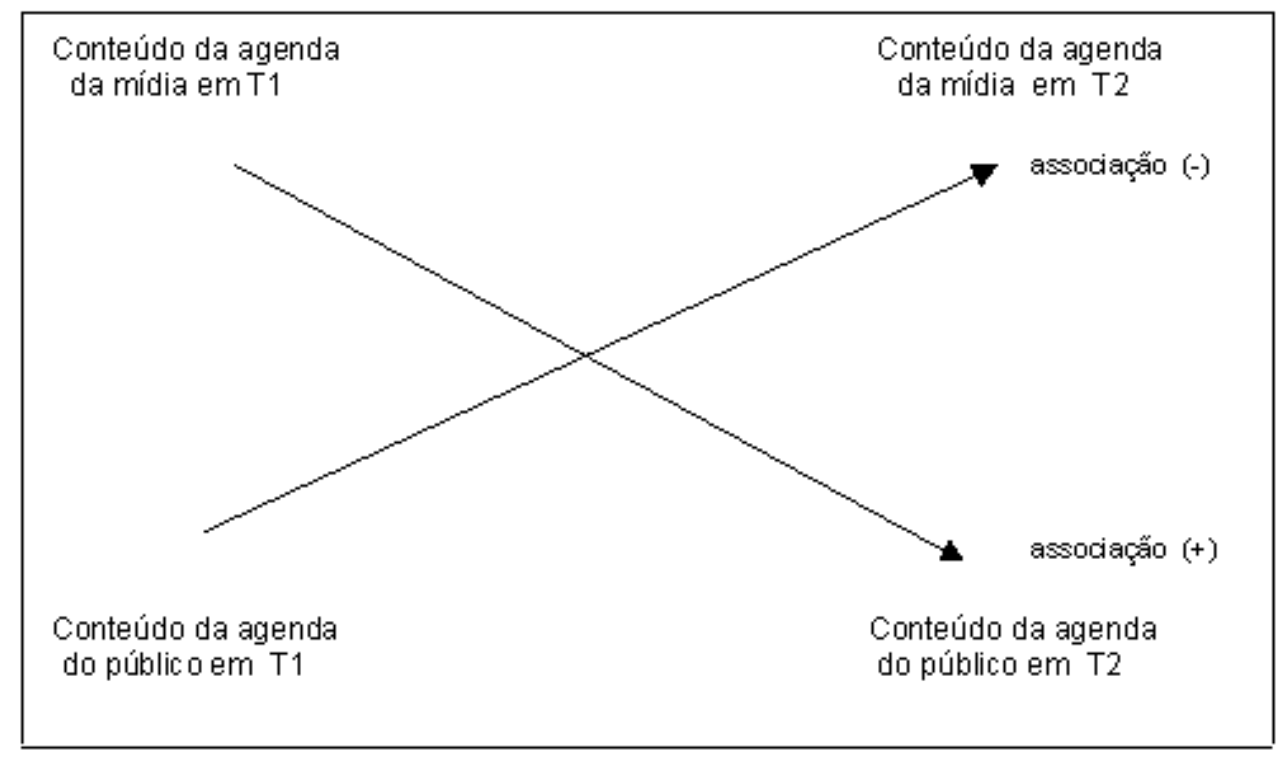

\footnotetext{
${ }^{12}$ Aliás, as campanhas eleitorais passaram a ser o ambiente preferido para a realização dos testes de hipóteses da agenda-setting.

${ }^{13} \mathrm{O}$ estudo considerou os seguintes veículos de comunicação: duas redes nacionais de televisão (CBS e NBC); quatro jornais locais; e um jornal nacional (New York Times).

${ }^{14}$ MCCOMBS, Maxwell; SHAW, Donald. The agenda-setting function of mass media, Public Opinion Quarterly, Vol. 36, pp. 176-185, 1972.
} 
De acordo com Shaw, a hipótese da agenda-setting concebe que

Em conseqüência da ação dos jornais, da televisão e dos outros meios de comunicação, o público sabe ou ignora, presta atenção ou descura, realça ou negligencia elementos específicos dos cenários públicos. As pessoas têm tendência para incluir ou excluir dos seus próprios conhecimentos aquilo que os meios de comunicação incluem ou excluem do seu próprio conteúdo. Além disso, o público tende a atribuir àquilo que esse conteúdo inclui uma importância que reflete de perto a ênfase atribuída pelos meios de comunicação aos acontecimentos, aos problemas, às pessoas ${ }^{15}$ (SHAW, 1979, p. 96).

Nesse período inicial ${ }^{16}$, a hipótese da agenda-setting não defende a idéia de que a mídia busca persuadir, mas, ao descrever e apresentar as notícias, apresenta ao público uma lista daquilo que é necessário para ter uma opinião e discutir. O pressuposto fundamental da agenda-setting é que a compreensão que as pessoas têm de grande parte da realidade social lhes é fornecida, por empréstimo, pelos meios de comunicação (Shaw, 1979, p. 96, 101).

Como podemos observar no QUADRO 1.2, a agenda-setting ${ }^{17}$ é o processo em que a mídia transfere para as pessoas as questões mais importantes a serem debatidas num período de tempo particular. Nesse processo, o público atribui a mesma importância aos assuntos discutidos pelos meios de comunicação.

\footnotetext{
${ }^{15}$ Apud WOLF, 1999, p. 144.

${ }^{16}$ Outras fases da agenda-setting, no entanto, alargaram a compreensão do impacto da mídia nas pessoas. A segunda fase caracterizou-se pela análise mais detalhada da influência dos meios de comunicação, através da investigação acerca das condições em que a agenda da mídia influencia mais efetivamente o público. Um terceiro estágio refere-se aos estudos que consideram que a mídia não só é capaz de transmitir saliência aos assuntos, mas também lhes dar atributos, ou seja, pode dizer também como as pessoas devem pensar. Dessa maneira, as pesquisas da agenda-setting passaram a observar o modo como as issues são divulgadas nas notícias.

${ }^{17}$ Agendamento foi o termo utilizado para traduzir o termo agenda-setting. TRAQUINA, 2001, p. 47.
} 
QUADRO 1.2 - Papel da agenda -setting dos meios de comunicação de massa

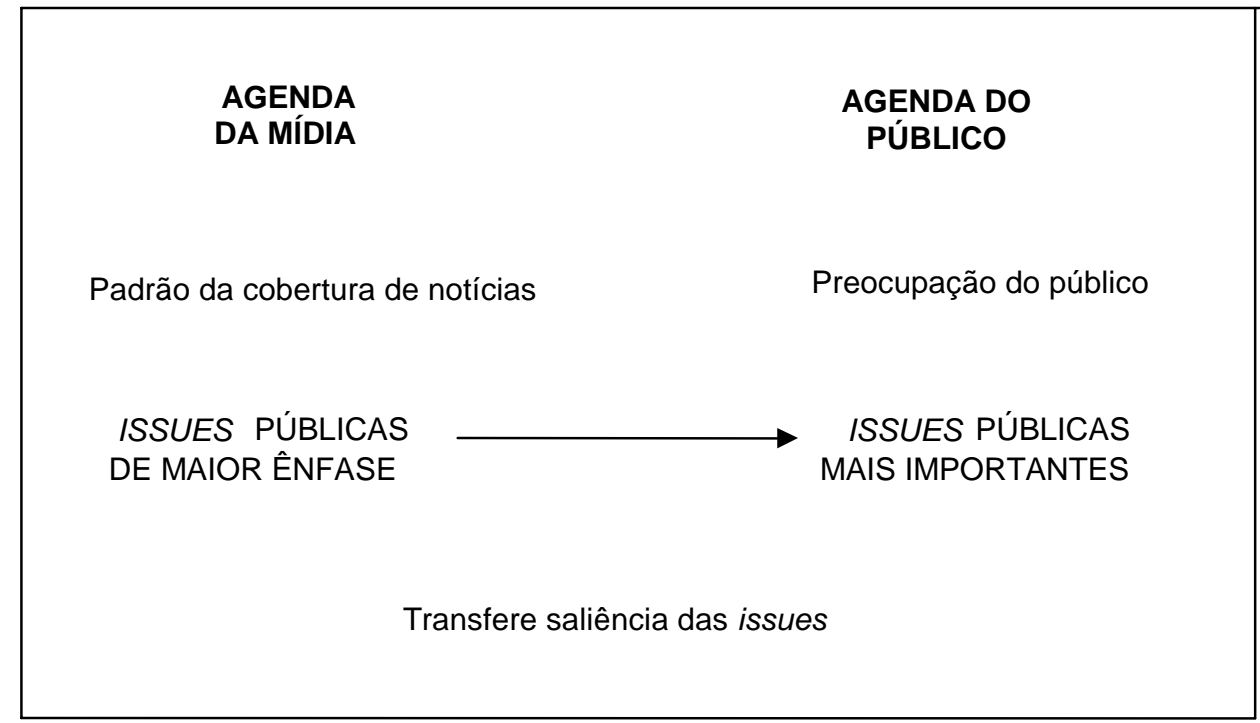

Fonte: Maxwel, McCombs (2004, p.5).

No que diz respeito à metodologia da agenda-setting, a comparação entre a agenda ${ }^{18}$ da mídia e a do público é o principal procedimento

${ }^{18}$ O termo agenda é definido como uma lista de questões (issues) que são vistas num determinado período e classificadas conforme uma hierarquia de importância. Ver ROGERS e DEARING, 1988, p. 565. 
instrumental. O processo de agendamento ou de transferência das prioridades dos assuntos da primeira agenda para a segunda, num determinado período observado entre as duas pautas, configura a agenda-setting.

Geralmente se utiliza a análise de conteúdo para o levantamento da agenda da mídia e grupos focais e/ou surveys de amostragem aleatória intencional de uma determinada audiência para o conhecimento da agenda das pessoas. Segundo Becker, McCombs e McLeod (1975), a influência da mídia no público pode ser avaliada através de três modelos ${ }^{19}$. O primeiro é o modelo de conhecimento e diz respeito apenas à presença ou ausência de um tema da mídia na agenda do público. O segundo é o de realce que se preocupa com a influência de alguns temas, dois ou três, da agenda da mídia, na agenda das pessoas e não com o grau de replicação de toda a agenda dos meios de comunicação no público. O terceiro modelo é o das prioridades que se refere à reprodução de uma hierarquia de temas disseminados pela mídia na discussão da agenda das pessoas.

Como a influência da mídia é estudada em um longo espaço de tempo, coloca-se o problema de definir a dimensão temporal ótima para a averiguação da influência da pauta da mídia no público. De acordo com Eyal, Winter e De George (1981), cinco parâmetros temporais podem ser estabelecidos:

1) frame temporal: é todo o período de levantamento dos dados das duas agendas em observação (dos meios de comunicação e do público), ou a extensão global do tempo em que se efetua a verificação do efeito;

2) intervalo temporal (time-lag), isto é, o período em que se estende o levantamento da variável independente (a cobertura informativa da mídia) e o levantamento da variável dependente (a agenda do público);

3) a duração do levantamento da agenda dos meios de comunicação, ou seja, o período global de cobertura informativa durante o qual se 
levanta a agenda, por intermédio da análise de conteúdo (no caso da campanha, integralmente);

4) a duração do levantamento da agenda do público ou o período durante o qual é analisado o conhecimento que o público possui acerca dos assuntos mais significativos;

5) a duração do efeito ótimo ou do período em que se estabelece a máxima associação entre os temas dos meios de comunicação e o realce destes no conhecimento do público ${ }^{20}$.

Sobre essa questão da adoção de parâmetros temporais para verificar o efeito da mídia na agenda do público, o estudo clássico é o de Winter e Eyal (1981). Os autores se preocuparam em investigar qual é o tempo que leva para um assunto que é discutido nos meios de comunicação influenciar as pessoas. Winter e Eyal compararam a saliência dos direitos civis na agenda pública com o conteúdo da primeira página do New York Times em vinte e três anos. Para cada ano, analisaram a influência do conteúdo das notícias do jornal de seis meses que precederam às pesquisas de opinião pública Gallup. A força da correlação foi de $+0,71$ para o mês da cobertura das notícias precedente à pesquisa de opinião pública. Para o segundo mês a correlação foi de $+0,70$. Para o terceiro, quarto, quinto e sexto meses a correlação diminuiu para $+0,38$. Os autores concluíram a partir dos resultados que a influência da mídia na agenda do público não é imediata, mas ocorre de acordo com um intervalo temporal (time-lag) de um a dois meses ${ }^{21}$.

\subsection{Referencial teórico}

\footnotetext{
${ }^{19}$ Ver WOLF, 1999, p. 174.

${ }^{20}$ Ver EYAL, WINTER e DE GEORGE, 1981, p. 212.

21 Trabalhos mais recentes concluíram que o time-lag ideal para verificar o efeito da transferência da saliência dos assuntos da mídia para a discussão da agenda pública é entre 4 a 8 semanas. Além disso, o efeito pode variar de acordo com a natureza da issue.
} 
Embora a literatura da comunicação política tenha acumulado ampla evidência sobre o impacto da mídia no público, dentro ou fora do período da campanha eleitoral, são praticamente inexistentes, até a década de oitenta ${ }^{22}$, os estudos da agenda-setting que se preocuparam com as origens da formação da agenda de campanha e a possível influência dos candidatos e lideranças políticas na formação da agenda da mídia em épocas eleitorais.

A partir do questionamento sobre se os atores políticos são elementos importantes na elaboração da pauta da campanha e se há ou não alguma associação entre a agenda política e a lista de questões enfatizadas pela mídia em período de eleições, os estudos da agenda-setting passaram a prestar atenção no processo da formação da agenda dos meios de comunicação ${ }^{23}$.

Essa nova perspectiva, que de acordo com McCombs (2004) é a fase mais recente da agenda-setting, passou a examinar a agenda da mídia como uma variável dependente a ser explicada, ao contrário do que ocorria na fase inicial da agenda-setting, em que a agenda da mídia era tomada como variável independente. Desse modo, houve a admissão de que a agenda da mídia é subsidiada por organizações, grupos de interesses e campanhas políticas, como mostra o QUADRO 1.3.

\footnotetext{
${ }^{22}$ Embora seja importante salientar que Blumler e Gurevitch já haviam concebido, em 1975, vários fatores que podiam interferir na agenda da mídia numa campanha eleitoral, como a forma do sistema de mídia nacional, grau de profissionalização das campanhas, da interação entre jornalistas e partidos, grau de dependência da mídia do estado e legitimidade da mídia. BLUMLER, J. G. e GUREVITCH, M. Towards a Comparative Framework for Political Communication Research. In: Political Communication (London, Sage, 1975).

${ }^{23}$ Tichenor (1982) foi um dos primeiros autores a questionar sobre quem agenda a agenda da mídia. Segundo o autor, a agenda da mídia recebe influências de outros atores, como partidos, candidatos, lideranças, etc. Ver TICHENOR, P. J. Agenda-setting: media as political kingmakers? (In: Journalism Quartely, 59, p. 488-490, 1982).
} 
QUADRO 1.3. Expansão da teoria da agenda-setting

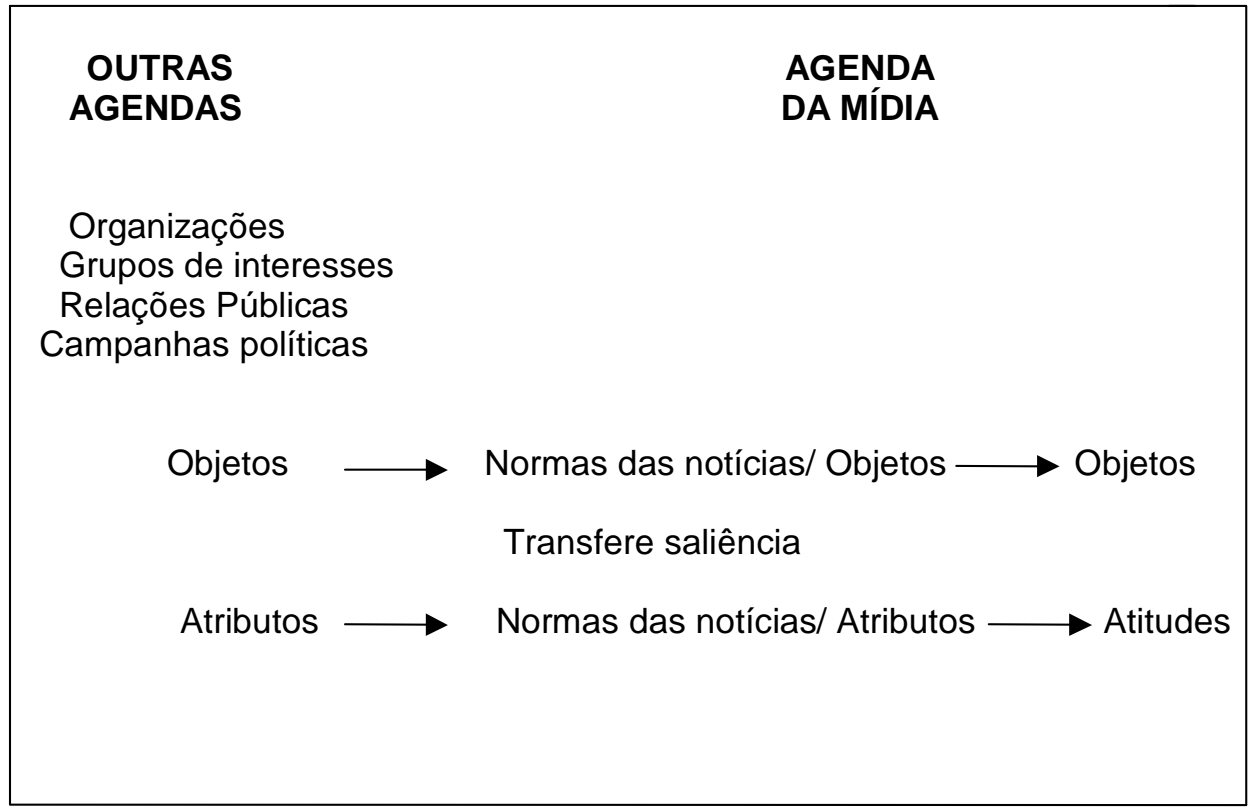

Fonte: Maxwell McCombs (2004, p. 99).

No caso específico de períodos das campanhas eleitorais, a agenda da mídia pode sofrer influência direta da agenda dos partidos políticos e candidatos. Ou em outras palavras, as candidaturas, através de seus discursos de campanha, programas de governo e comerciais de tevê podem pautar a agenda da mídia, transferindo para esta as suas prioridades.

De acordo com McCombs, a relação de competição entre a agenda da mídia e outras agendas pela elaboração da pauta pode ser compreendida através da "metáfora da cebola" ${ }^{24}$. As camadas da "cebola" representam os campos de influência no processo de formação da agenda da mídia, a qual, por sua vez, é representada pelo núcleo da "cebola". A metáfora ilustra a seqüência do processo em que uma camada mais externa afeta as camadas mais próximas do núcleo da "cebola", como podemos visualizar no QUADRO 1.4 .

\footnotetext{
${ }^{24}$ Os autores da "metáfora da cebola" são Shoemaker e Reese (1991).
} 


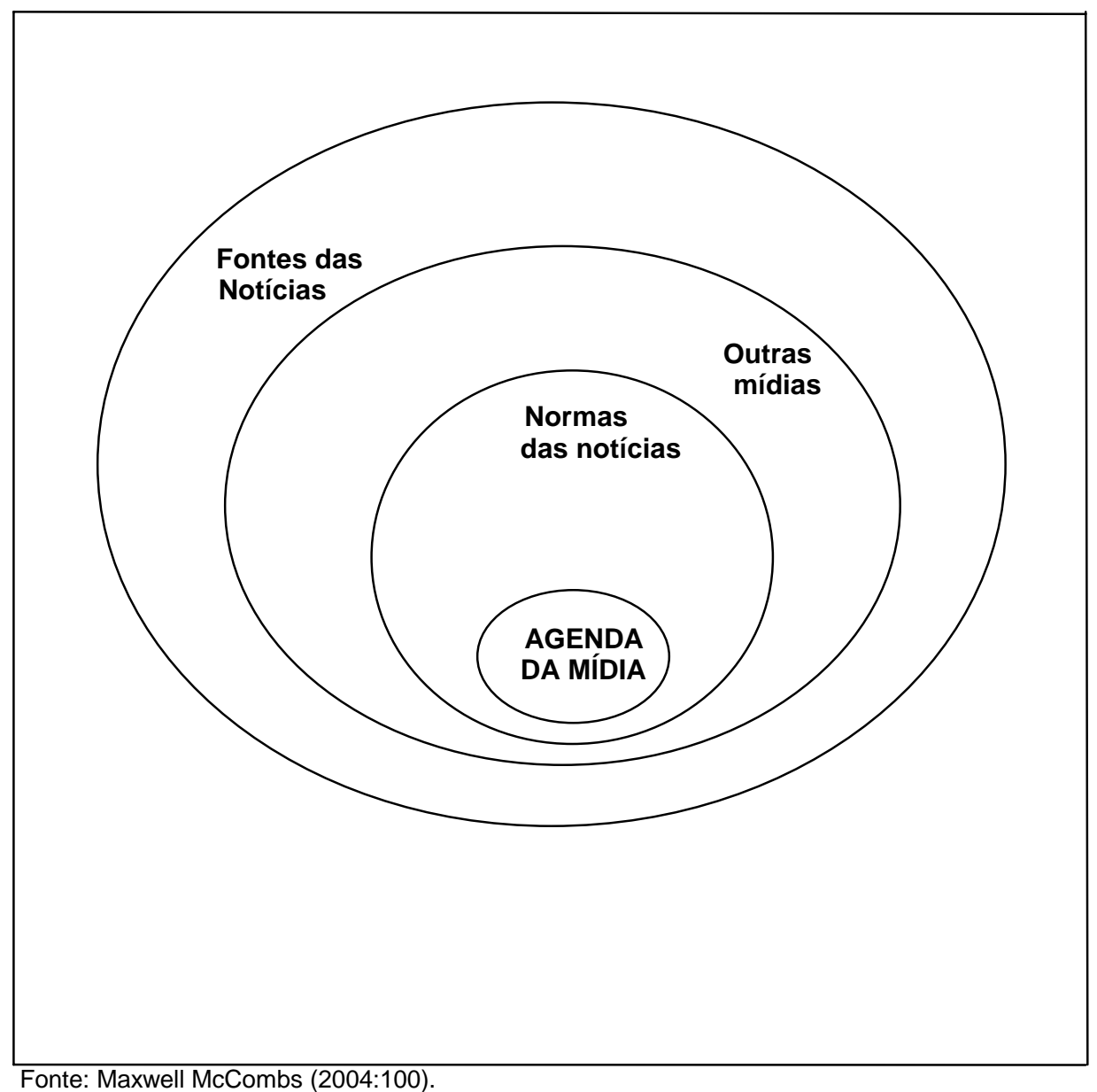

A camada mais externa da "cebola teórica" é composta pelas fontes, que podem ser o Presidente da República, organizações, grupos de interesses, partidos, candidatos, lideranças partidárias, profissionais de marketing, portavozes de campanha, etc. A camada "outras mídias" diz respeito à interação que ocorre entre as próprias mídias na definição das notícias diárias, através de um processo definido como agenda-setting entre as mídias (intermedia agenda- 
setting). A camada mais próxima do núcleo refere-se às normas profissionais do jornalismo consideradas pelos jornalistas na produção das notícias.

Vejamos, em primeiro lugar, a camada "fontes de notícias", oriunda da ação dos candidatos, em épocas eleitorais. É sabido que através da mídia os discursos dos políticos ganham maior credibilidade junto aos eleitores ${ }^{25}$, já que é preocupação do jornalismo comercial manter-se independente da política com o objetivo de legitimar o seu papel institucional na sociedade moderna (Mancini e Swanson, 1996). Desse modo, a mídia, em especial os noticiários de tevê, que são importantes fontes de informação para as pessoas, tornou-se vital para as campanhas modernas. Sabendo disso, os políticos e suas equipes elaboram suas campanhas políticas com o intuito de chamar a atenção da mídia para si. A principal forma das candidaturas capturar a atenção dos jornalistas é através dos "pseudo-eventos", ${ }^{26}$ ou seja, aparições públicas, viagens, comícios, passeatas, discursos públicos, etc., que são eventos planejados pelas equipes de campanha, voltados para a cobertura da mídia, em particular a da televisão (Boorstin, 1961; Nimmo, 1970).

Além disso, para influenciar a agenda da mídia os políticos se valem da propaganda eleitoral televisiva ${ }^{27}$, das conferências de imprensa, releases destinados à divulgação nos meios de comunicação, respostas a perguntas da mídia, sound bites $^{28}$, participação em talk-shows, entrevistas e debates de televisão. Uma outra forma dos políticos interferirem na agenda da imprensa é através das declarações de seus "porta-vozes" e advogados, além da figura profissional do spindoctor ${ }^{29}$ (Trent e Friedenberg, 1995).

Os comerciais de televisão, instrumento importante para os políticos tentar agendar a discussão do eleitor, também são uma maneira dos

\footnotetext{
${ }^{25}$ Schwartz,1972, 1976; Ranney, 1983.

${ }^{26}$ Os "pseudo-eventos" são "medialidades" que só foram possíveis graças à presença da televisão, pois sem ela esses eventos não tomariam a importância que ganham nas campanhas. De acordo com ROBINSON, 1981 e RANNEY, 1983.

${ }^{27}$ Até 1988 era comum parte dos discursos dos anúncios de tevê comporem as notícias da cobertura eleitoral dos candidatos. Ver JAMIESON, 1993.

${ }^{28}$ Segundo Hallin (1992), bloco de discurso ininterrupto dos candidatos durante as notícias dos telejornais.

${ }^{29}$ Espécie de assessor de imprensa que é contratado para conduzir a cobertura da mídia em favor da candidatura para qual está trabalhando.
} 
candidatos influenciar a pauta das notícias da mídia nas campanhas eleitorais. Schwartz chamou a situação em que os candidatos transpõem para os meios de comunicação as questões de campanha discutidas na propaganda política de "processo de sincronização" entre a propaganda eleitoral e a mídia (Schwartz, 1972; 1976).

Ainda a esse respeito da relação entre comerciais de televisão e a cobertura política da mídia, Jamieson (1993) observou que os comerciais negativos, baseados em conflitos e ataques contra adversários, são freqüentemente usados pelos políticos como estratégia para influenciar a agenda da mídia nas campanhas, uma vez que os critérios de noticiabilidade ${ }^{30}$ adotados pelos jornalistas em coberturas eleitorais priorizam esse tipo de assunto.

Sobre essa questão da propaganda negativa como atrativo para a mídia, Johnson-Cartee e Copeland (1997a) entendem que os jornalistas filtram os ataques e os conflitos gerados pelos políticos na campanha, pois a mídia funciona como uma espécie de árbitro, que decide quais conflitos serão divulgados:

Negative political advertising is frequently used as both media bait, as it attracts the attention of the news, and as an assault against the opponent. This fits into the news values of negativity and conflict. In addition, negative political advertising is ripe for the news media's horse-race interpretations. A negative ad is like a tennis ball slammed over the net, and the news media are as umpires who decide if it is a "fair" ball or not (JOHNSON-CARTEE e COPELAND, 1997a, p.33)

A camada "outras mídias" refere-se ao processo no qual os diversos meios de comunicação (jornais, revistas, Internet, televisão e rádio) influenciam-se mutuamente na elaboração da pauta diária da mídia. Bourdieu ${ }^{31}$

\footnotetext{
${ }^{30}$ Ver discussão mais adiante.

31 1997, p. 30.
} 
denomina esse processo de "circulação circular da informação", responsabilizando-o por tornar os produtos jornalísticos homogêneos.

As normas profissionais dos jornalistas são um outro fator (camada) de influência da agenda da mídia, considerada pelos jornalistas na seleção acerca de quais assuntos se tornarão notícias. De acordo com Gitlin (1980), os processos de escolhas dos jornalistas sobre o que publicar diariamente, levam em conta: os fatos que envolvem acontecimentos e não as condições que produzem os acontecimentos; as matérias que privilegiam as pessoas e não os grupos; as notícias que destacam o conflito e não o consenso; as notícias que privilegiam o fato que alimenta a notícia e não o fato que o explica. Tuchman (1978) lembra ainda que é um critério de seleção ou de noticiabilidade a prática da "notícia reação", isto é, o jornalista procura um comentário de reação a um acontecimento.

Alguns estudos investigaram como as coberturas eleitorais das emissoras de tevê norte-americanas são realizadas conforme as normas de tradição do jornalismo. A seguir, descrevo alguns deles, com a finalidade de mostrar como essas normas interferem na escolha dos assuntos a serem veiculados durante as coberturas eleitorais da mídia.

Ao acompanhar a cobertura da eleição presidencial norte-americana de 1992 na CNN e ABC, Kerbel (1994) observou que o critério de noticiabilidade adotado para a seleção de notícias deu prioridade aos enfoques das estratégias, táticas dos candidatos, andamento da campanha, controvérsias entre os políticos (tanto no plano pessoal como relativo às issues) e horserace $^{32}$, em desvantagem da discussão sobre políticas públicas, ou seja, da pauta mais substantiva.

O estudo de Patterson (1980), acerca da cobertura dos noticiários de tevê da eleição presidencial de 1976 nos Estados Unidos, mostrou que a cobertura da mídia realizou-se em forma de "jogo"33 (game schema), ou seja,

\footnotetext{
${ }^{32}$ Notícias que retratam a disputa eleitoral como uma "corrida de cavalos", isto é, as pesquisas.

${ }^{33}$ Segundo Patterson a cobertura de "jogo" das notícias da primeira página do New York Times sofreu uma predominância progressiva sobre a cobertura de enfoque político (policy schema),
} 
divulgou mais as notícias sobre a competição entre os políticos (pesquisas e estratégias) e agenda da campanha dos candidatos (comícios, viagens, passeatas, etc.). A cobertura do enfoque político substantivo (policy schema), isto é, baseado em propostas de políticas públicas (policies), posições políticas dos candidatos perante as issues e as capacidades pessoais e de governo recebeu, ao contrário, uma atenção muito limitada. Apenas 30\% da cobertura foi relativa à forma "substantiva" e $60 \%$ de "jogo". De acordo com Patterson, a cobertura "substantiva" interessa menos aos jornalistas porque os critérios de seleção das notícias entendem que os assuntos são poucos atrativos para a audiência por serem estáticos. Já os assuntos em forma de "jogo", por serem mais dinâmicos e despertar mais interesse nos telespectadores, são de maior preferência dos jornalistas.

Estudos sobre eleições mais recentes dos Estados Unidos, como o de Buchanan (2001), demonstram que o enfoque nas pesquisas nas coberturas da mídia norte-americana sofreu uma queda da eleição presidencial de 1988 para a de 1992 , passando de $36 \%$ para $30 \%$, mas que aumentou no pleito de 1996 , chegando a 48\%. Já a categoria de issues tem aumentado gradualmente nas eleições, de 10\% em 1988, para 31\% em 1992 e para 37\%, em $1996^{34}$.

Em geral, os estudos sobre o conteúdo das coberturas eleitorais da mídia nos Estados Unidos, principalmente acerca dos noticiários de televisão, têm encontrado resultados similares, ou seja, a maioria tem concluído que as coberturas presidenciais norte-americanas focalizam mais o "sobe e desce" dos candidatos nas pesquisas eleitorais e descrição da agenda da campanha das candidaturas do que a cobertura de propostas de políticas e issues (Sigal, 1973; Carey, 1976; Barber, 1978; Graber, 1980; Paterson, 1980; Berkman \& Kitch, 1986; Semetko et al., 1991; Kerbel, 1994; Williams, Shapiro \& Cutbirth, 1991; Buchanan, 2001). Estes trabalhos também concluem que essa

nas eleições presidenciais norte-americanas do período entre 1960 a 1992. Ver PATTERSON, 1980, p. 74.

${ }^{34}$ Projeto de Markle e Luce Press Clipping Service (ver BUCHANAN, 1991: 38-74). Baseado: nas matérias de campanha e editoriais de 13 principais jornais e nos noticiários de tevê da NBC, ABC, CBS, CNN e PBS, entre 8 de setembro e 8 de novembro de 1988; nas matérias de campanha e editoriais do New York Times, Washington Post, Wall Street Journal, NBC, ABC, 
característica das coberturas eleitorais norte-americanas deve-se às normas dos jornalistas, ou seja, aos critérios de noticiabilidade, que priorizam assuntos que dão mais audiência.

\subsection{Estudos empíricos}

Existe no âmbito da literatura internacional sobre agenda-setting uma grande gama de estudos realizados a respeito da influência dos políticos na agenda da mídia, principalmente acerca de períodos eleitorais. Seguem-se alguns exemplos de trabalhos sobre eleições que utilizam o modelo da agendasetting para a verificação da capacidade dos atores políticos transferirem para a cobertura da mídia a saliência das issues públicas discutidas em suas pautas.

O trabalho de Asp (1983) comparou a agenda dos partidos políticos (Comunista, Social-Democrata, Centro, Liberal e Conservador) com o conteúdo divulgado pela mídia (telejornais), durante a campanha da Suécia de 1979. Das cinco correlações efetuadas, três não tiveram significância, o que levou o autor rejeitar a hipótese de que os partidos conseguiram transferir suas prioridades para a cobertura dos noticiários de televisão, pois esses últimos estabeleceram uma hierarquia própria das questões durante a campanha, independentemente da pauta dos partidos.

Semetko, Blumler, Gurevitch e Weaver (1991) encontraram diferenças marcantes no estudo da influência da agenda dos políticos no conteúdo da cobertura da mídia entre a Grã-Bretanha e Estados Unidos. Nas eleições gerais britânicas de 1983, os candidatos obtiveram um enorme sucesso na divulgação de suas issues nos noticiários e jornais. Os autores compararam a ênfase de cinco issues dos candidatos ${ }^{35}$ (do Partido Conservador, Trabalhista e da Aliança) com a cobertura dessas issues em cinco jornais (Daily Mirror, The

CBS,CNN e PBS, entre 7 de setembro e 3 de novembro de 1992; e nas matérias de campanha e editoriais da ABC, CBS e NBC, entre 2 de setembro e 2 de novembro de 1996.

${ }^{35}$ A análise de conteúdo das issues foi realizada a partir dos discursos que os candidatos fizeram diariamente pelas manhãs junto à mídia no período eleitoral de 1983. 
Sun, Dily Mail, The Times e The Guardian) e em duas emissoras (BBC e ITV), encontrando uma correlação média de $+0,70$. Os resultados das associações foram rodadas 21 correlações, cada agenda de um candidato foi comparada com a cobertura eleitoral dos sete meios - variaram entre $+0,30$ e 0,90 . Seis correlações tiveram em média o valor de $+0,70$ e somente cinco apresentaram valores abaixo de $+0,70$. Estes resultados permitiram a conclusão de que os candidatos tiveram êxito em transferir para a pauta da cobertura dos jornais bem como dos noticiários de televisão a saliência das questões discutidas em seus discursos.

Em contraste, na eleição norte-americana de 1984, os autores encontraram baixos resultados entre a correlação de seis issues da agenda dos candidatos (democrata e republicano) e a agenda da cobertura de tais issues pelos jornais (Indianápolis Star, Lousiville Courier-Journal) e noticiários de televisão ( $A B C, N B C$ e $C B S$ ). As correlações encontradas não excederam $+0,31$ e três, das seis correlações, foram negativas ou zero. Quando foram realizadas as correlações somente considerando os assuntos substantivos (propostas de políticas públicas e issues), os autores encontraram correlações altas entre a ordem dos assuntos substantivos discutidos na agenda dos candidatos e os destaques dados às issues nos noticiários de televisão e jornais norte-americanos.

Uma das explicações aferidas pelos autores sobre a diferença encontrada entre os dois países é que na Grã-Bretanha, pelo menos até aquela eleição, as normas que orientavam a cobertura eleitoral buscavam dar proeminência a assuntos sobre programas de governo dos candidatos, enquanto nos Estados Unidos, as normas dos jornalistas eram mais voltadas para a garantia de audiência, e por isso davam preferência aos assuntos como pesquisas e agenda de campanha. Ou seja, os jornalistas norte-americanos levavam em conta em suas coberturas os critérios de noticiabilidade, enquanto 
os jornalistas britânicos, naquela eleição específica, tiveram normas mais orientadas para uma cobertura "sacerdotal"

Apesar do estudo de Semetko, Blumler, Gurevitch e Weaver (1991) sugerir uma fraca influência dos políticos na cobertura da mídia nos Estados Unidos, McCombs (2004) ressalta que estudos mais recentes a respeito da formação da agenda de campanha têm demonstrado que os políticos norteamericanos são capazes de influenciar o conteúdo da mídia, principalmente em épocas eleitorais, isto é, obtém sucesso em enviar para a pauta dos meios de comunicação a hierarquia dos assuntos debatidos em suas agendas.

Miller, Andsager e Riechert (1998) compararam o conteúdo dos sites do candidato republicano com as coberturas da imprensa, nas primárias da nomeação presidencial norte-americana de 1996, e encontraram associações significantes entre a agenda da candidatura e as agendas da mídia escrita. A média das correlações efetuadas foi de +0,72. Lichter e Smith (1996) analisaram a elaboração da pauta da cobertura das notícias de tevê sobre as primárias de 1996 nos Estados Unidos. Os autores encontraram um grau moderado de correspondência $(+0,40)$ entre as ordens das issues dos candidatos e as ordens dos assuntos da cobertura dos noticiários de televisão. O estudo de Tedesco (2001) mostra que houve correspondência entre a agenda dos candidatos e a agenda da cobertura das notícias das redes de tevê, durante as primárias de 2000 nos Estados Unidos. As correlações realizadas variaram entre +0,64 e +0,68. A análise do cross-lagged correlations (testes que verificam a influência de uma agenda na outra e vice-versa, de acordo com intervalos temporais determinados) indicou correlações mais altas na direção da influência dos candidatos nos noticiários do que o inverso.

Além desses estudos sobre períodos de campanhas, McCombs (2004) verificou, em períodos não-eleitorais, a relação entre a agenda das prioridades dos presidentes Nixon, em 1970, Jimmy Carter, em 1978 e Ronald Reagan, em

\footnotetext{
${ }^{36}$ Termo utilizado por Semetko, Blumler, Gurevitch e Weaver (1991). Segundo os autores, a "orientação normativa sacerdotal" (sacerdotal normative orientation) dos jornalistas britânicos considera a campanha eleitoral um evento muito significativo e que por isso não deve ser determinado pelas aplicações práticas dos valores das notícias.
} 
1982, com a agenda dos meios de comunicação, nos respectivos períodos, e concluiu que em algumas épocas o presidente consegue influenciar a agenda da mídia, enquanto em outras não. No mesmo trabalho McCombs analisa o caso canadense e, levando em consideração somente as issues, observa diferenças relevantes quanto ao poder de influência da agenda dos políticos na agenda da mídia no que se refere às questões sobre "inflação" e "meioambiente". A esse respeito, o autor ressalta que a questão do meio-ambiente teve mais sucesso em influenciar a pauta da mídia do que a inflação, o que seria indicativo de que os jornalistas dão preferência às questões que os eleitores têm pouca experiência cotidiana (unobstrusive issues), como foi o caso do tema meio-ambiente. Isto significa que os políticos que trabalham com uma agenda mais voltada para as unobstrusive issues teriam maior possibilidade de ver sua agenda refletida na pauta da mídia.

\subsection{Modelo de análise, hipóteses e metodologia}

Posto que os estudos mais recentes de agenda-setting preconizam haver uma associação, em épocas eleitorais, entre a agenda dos candidatos e a dos jornalistas, de modo que os candidatos obtêm sucesso em transferir para a pauta dos profissionais da mídia a prioridade dos assuntos de suas agendas, busco examinar em que medida esse processo de agenda-setting ocorreu na eleição presidencial brasileira de 2002.

A seguir, através da FIG. 1.1, apresento o esquema do processo da agenda-setting da eleição presidencial de 2002 em análise neste estudo.

FIGURA 1.1 - Esquema do processo da agenda-setting da eleição presidencial de 2002 em análise

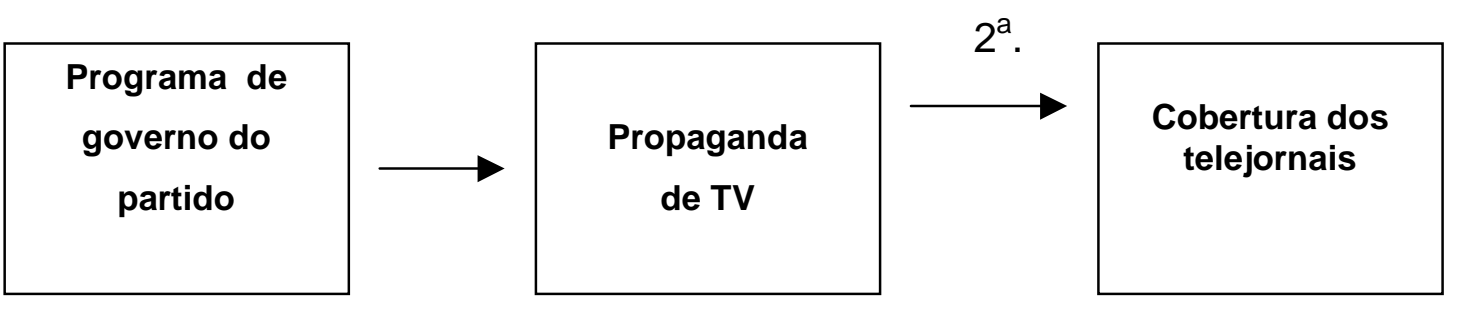


De acordo com a figura, a primeira seta diz respeito à influência do programa de governo partidário na propaganda eleitoral do candidato. A segunda seta indica a influência da propaganda das candidaturas em suas coberturas, realizadas pelos noticiários de televisão, levando em conta um intervalo temporal entre a veiculação do conteúdo da propaganda e o conteúdo divulgado nas coberturas. A terceira seta é oposta à segunda, ou seja, referese à influência da pauta dos noticiários na propaganda dos candidatos, considerando intervalos temporais entre a emissão do conteúdo da primeira e a veiculação da agenda de assuntos da segunda.

A primeira questão a ser investigada neste estudo está relacionada à elaboração da agenda dos noticiários sobre as candidaturas nos telejornais, na campanha para presidência da República de 2002. A indagação que me move é a seguinte. Houve associação entre a agenda dos candidatos, veiculada na propaganda eleitoral de televisão, e a agenda das coberturas das candidaturas nos telejornais? Houve influência do conteúdo da propaganda dos candidatos na elaboração da pauta dos jornalistas? Ou foi a agenda dos telejornais que influenciou o conteúdo da campanha na tevê dos candidatos?

Uma segunda questão é a respeito da construção da agenda da propaganda de televisão dos candidatos. Trata-se de verificar se o PT, por exemplo, que discutiu e aprovou, em suas instâncias partidárias um programa de governo direcionado para a campanha de 2002, influenciou ou não a agenda de seu candidato à presidência da República. Ou melhor dizendo, será que o PT obteve êxito em transferir para a agenda da propaganda de televisão 
de Lula, a saliência dos assuntos mais importantes enfatizados em sua plataforma? Ou o fato do partido ter elaborado um programa de governo não significou que tenha havido uma influência partidária na pauta da campanha da candidatura Lula?

É importante ressaltar que a conjetura de influência da agenda partidária só foi possível no caso do PT, que divulgou um programa de governo para a campanha depois de ter submetido este à discussão e aprovação da base partidária. No caso da candidatura de Serra, o programa de governo da campanha apresentado na eleição foi somente aquele elaborado pelo candidato, longe, portanto, de qualquer discussão partidária.

Para a realização deste trabalho, em particular, somente considerei duas candidaturas: a do petista Luiz Inácio Lula da Silva e a do tucano José Serra. Esse recorte se deveu, em primeiro lugar, ao fato de ter sido estas as duas candidaturas que disputaram o segundo turno, e, em segundo, em virtude da amplitude que o trabalho ganharia, caso viesse incluir os candidatos Ciro Gomes e Anthony Garotinho na análise.

Os esquemas, referentes à análise do processo da agenda-setting da agenda das duas candidaturas investigadas, podem ser visualizados na FIGURA 1.2 e 1.3.

FIGURA 1.2 - Processo da agenda-setting da candidatura Lula na tevê

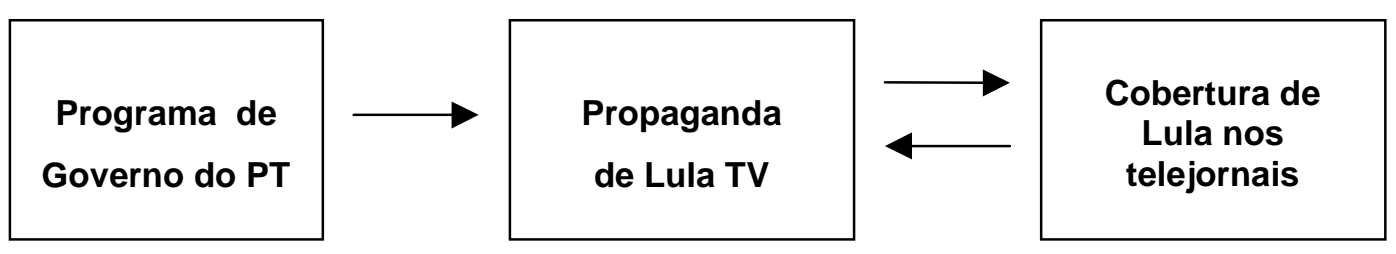

FIGURA 1.3 - Processo da agenda-setting da candidatura Serra na tevê 


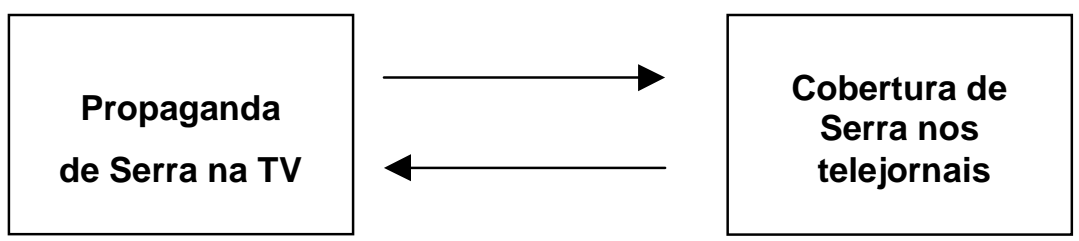

A seguir, exibo todas as hipóteses a serem testadas neste estudo.

Hipótese 1: a agenda do programa de governo do PT transferiu para o conteúdo da propaganda eleitoral de Lula na televisão suas prioridades de assuntos;

Hipótese 2: as prioridades dos assuntos da pauta da propaganda eleitoral de Lula na televisão estão associadas às prioridades dos assuntos do noticiário sobre a campanha de Lula nos telejornais;

Hipótese 3: as prioridades dos assuntos da agenda da propaganda eleitoral de Serra na televisão estão associadas às prioridades dos assuntos da cobertura eleitoral de Serra nos telejornais;

Hipótese 4: a pauta da propaganda eleitoral de Lula na televisão transferiu para a cobertura de Lula nos noticiários as suas prioridades de assuntos;

Hipótese 5: a cobertura eleitoral de Lula nos telejornais transferiu para a agenda da propaganda de Lula as suas prioridades de assuntos;

Hipótese 6: a propaganda eleitoral de Serra na televisão transferiu para a agenda da cobertura eleitoral de Serra nos telejornais suas prioridades de assuntos; 
Hipótese 7: a cobertura eleitoral de Serra na televisão transferiu para o conteúdo da propaganda de Serra na televisão suas prioridades de assuntos;

Quanto aos procedimentos metodológicos, foram construídos três bancos de dados ${ }^{37}$. O primeiro com o conteúdo dos programas de governo do PT e de José Serra. No caso do PT, o documento "Concepção e Diretrizes do Programa de Governo do PT para o Brasil"38, aprovado pelo partido na Resolução do XII Encontro Nacional do PT, de dezembro de 2001, e publicado no site oficial do partido em março de 2002, forneceu material básico para o trabalho; diferentemente, no caso do PSDB, dado à inexistência de um programa de governo partidário, direcionado para a campanha de 2002, não foi possível verificar a influência do PSDB, enquanto partido, na agenda da campanha do candidato. Desse modo, utilizei o programa de governo de Serra, "Trabalho e Progresso para Todos"39, lançado em agosto de 2002, para fazer a análise de conteúdo.

O segundo banco foi constituído com o conteúdo da propaganda eleitoral de tevê, ou seja, do Horário Gratuito de Propaganda Eleitoral de Televisão e dos anúncios ou inserções comerciais (spots) de 30 ou 60 segundos. Foram pesquisados, no primeiro turno, os programas do horário eleitoral das candidaturas de Lula e Serra, da tarde e noite, bem como os spots apresentados no período entre 20 de agosto a 3 de outubro (às terças-feiras, quintas-feiras e sábados). Da mesma forma, foram pesquisados os programas eleitorais de tevê (veiculados à tarde e noite) e os spots, no segundo turno, relativos ao período entre 14 a 25 de outubro (de segunda a domingo).

O terceiro banco foi elaborado a partir da cobertura eleitoral realizada pelos telejornais. Os dois telejornais pesquisados foram o Jornal Nacional e o Jornal da Record. O primeiro noticiário de tevê foi escolhido por ser o de maior

\footnotetext{
${ }^{37}$ A lista de variáveis e categorias encontra-se em anexo.

${ }^{38}$ Endereço eletrônico: <www.pt.org.br>.

${ }^{39}$ Endereço eletrônico: <www.joseserra.com.br>.
} 
audiência no país. Já o Jornal da Record, além do critério da audiência ${ }^{40}$, levou-se em conta o fato de Boris Casoy ser o principal âncora do telejornalismo brasileiro ${ }^{41}$ e considerado um formador de opinião. O conteúdo dos telejornais estudados reportou-se à parte dedicada à cobertura das candidaturas Lula e Serra. Os temas que se referiram simultaneamente às duas candidaturas foram classificados tanto para Lula, como para Serra. O período considerado para a análise, no primeiro turno, foi de 8 de agosto a 5 de outubro (de segunda a sábado), e, no segundo turno, de 7 a 26 de outubro (de segunda a sábado).

A análise de conteúdo, largamente empregada nos estudos internacionais da agenda-setting, foi a técnica adotada para o levantamento da agenda dos programas de governo, da propaganda de tevê e da cobertura eleitoral dos telejornais.

O tema foi tomado como unidade de análise da pesquisa e concebido de acordo com a definição de Berelson, ou seja, como: "uma afirmação acerca de um assunto. Quer dizer, uma frase, ou uma frase composta, habitualmente um resumo ou uma frase condensada, cuja influência pode afetar um vasto conjunto de formulações singulares" (BERELSON, 1952).

A regra de enumeração utilizada, no caso dos programas de governo, é a freqüência das menções dos temas. No caso da propaganda e cobertura eleitoral, contou-se os tempos de cada tema específico. Considerou-se que a importância ou prioridade de uma unidade de registro (tema) aumenta com a freqüência das menções e dos tempos.

Posteriormente ao levantamento dos temas das agendas, cada tema específico, juntamente com seus respectivos tempos e menções, foram submetidos à classificação nas seguintes categorias de assuntos: economia,

\footnotetext{
${ }^{40}$ Embora o Jornal da Record não tenha a audiência do Jornal Nacional, na época da eleição presidencial de 2002 esteve na disputa com outros telejornais pela segunda maior audiência do país. Ver gráfico, em anexo, da audiência do Jornal da Record durante o período da eleição presidencial de 2002.

${ }^{41}$ Consultar SQUIRRA, S. Boris Casoy - O Âncora no Telejornalismo Brasileiro (Petrópolis, Vozes, 1983).
} 
educação, saúde, segurança, social em geral (todas às vezes que apareceram a expressão social), fome, infra-estrutura, cultura/lazer/etnias, cidades, meioambiente, assuntos estrangeiros, Forças Armadas, regiões brasileiras, pesquisas eleitorais (descrição dos resultados de testes de opinião pública), campanha (descrição de eventos, passeatas, comícios, agenda do candidato, estratégias, táticas, avaliações da campanha, debates de tevê e apoios), qualidades pessoais (traços pessoais e biografia política), ataques ao adversário (pessoais ou sobre políticas), esperança (apelos de esperança), pátria (orgulho do país) e mudança. Os temas que não se encaixaram nessas categorias foram reunidos na categoria outros.

Os assuntos ainda foram classificados em duas categorias mais amplas: a dos assuntos substantivos e dos restantes. A categoria dos assuntos substantivos referiu-se às propostas dos candidatos, aos problemas do país e às questões (issues) sobre economia, educação, saúde, segurança, social em geral, fome, infra-estrutura, cultura/ lazer/ etnias, cidades, meio-ambiente, assuntos estrangeiros, Forças Armadas e regiões brasileiras. A categoria dos assuntos restantes constituiu-se pelas pesquisas eleitorais, campanha, além dos assuntos sobre as qualidades pessoais, esperança, pátria, mudança e ataques.

Foram levantadas seis agendas de assuntos, sendo duas dos programas de governo (uma do PT e outra de Serra); duas das propagandas de televisão (uma de Lula e outra de Serra); e duas das coberturas eleitorais dos telejornais (uma de Lula e outra de Serra). Os assuntos de cada agenda receberam uma hierarquização de acordo com a freqüência (tempo e menções) dos assuntos. Quanto mais alta a freqüência de um assunto, maior a prioridade dele numa determinada agenda.

Para os testes de hipóteses foram realizadas as comparações das prioridades hierarquizadas dos assuntos das agendas observadas, através do cálculo de correlações de spearman, escolha estatística que se justifica pelo 
uso comum nos estudos internacionais da fase inicial da agenda-setting que trabalham com variáveis categóricas.

A partir do modelo cross-lag correlations, utilizado por McCombs e Shaw (1972), no estudo da campanha presidencial de 1968 na cidade de Chapel Hill, é que realizo a análise das relações entre a agenda da propaganda dos candidatos e a agenda da cobertura dos dois telejornais mais importantes do Brasil, durante a campanha presidencial de 2002 (ver QUARO 1.5).

Os testes de hipóteses que buscaram verificar a transferência das prioridades dos assuntos da agenda da propaganda dos candidatos para 0 conteúdo da cobertura dos telejornais, bem como os testes das hipóteses inversas, foram efetuados levando em conta intervalos temporais entre a veiculação de uma agenda e de outra. Este aspecto dos parâmetros temporais adotados será mais detalhado quando forem apresentados os resultados dos testes das hipóteses, no capítulo 4.

QUADRO 1.5 - Modelo (Cross-lagged correlation) utilizado para a verificação da transferência do conteúdo da propaganda dos candidatos para o conteúdo da cobertura eleitoral de Lula e Serra nos telejornais (Jornal Nacional e Jornal da Record) na eleição presidencial de 2002

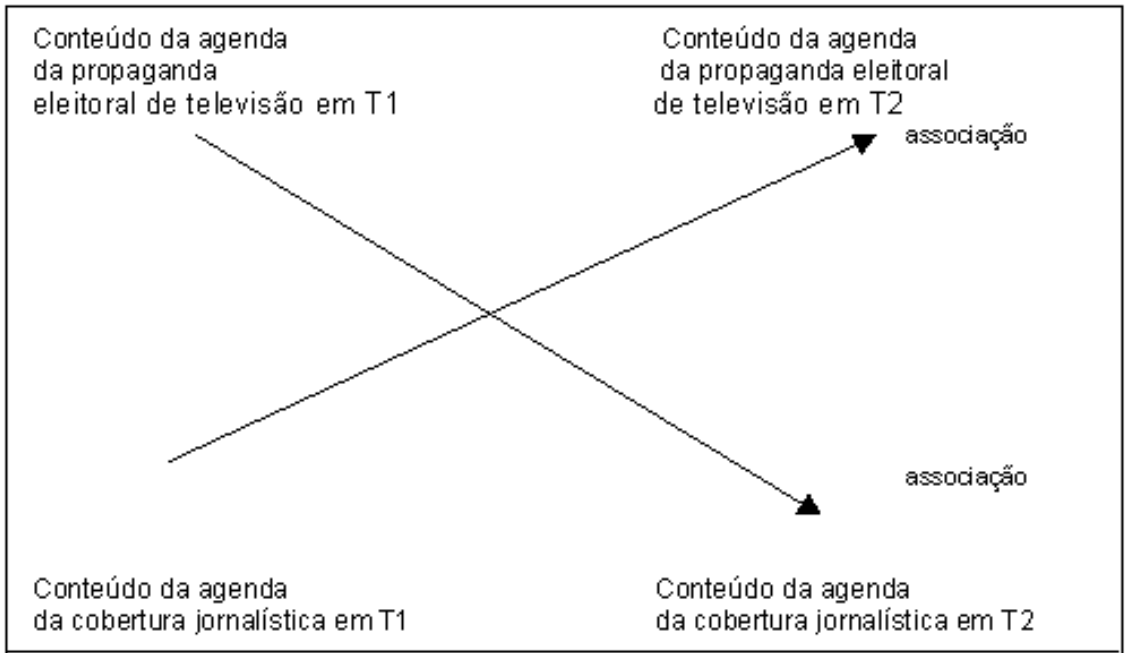


* As associações no modelo original são baseadas no spearman rho, que leva em conta o ordenamento das prioridades (e não as porcentagens) pela ótica do cidadão e o mesmo ordenamento no destaque dado aos assuntos na mídia.

\subsection{Conclusões}

Uma revisão iniciada na teoria da agenda-setting no início da década de 80 sugeriu que a agenda dos candidatos era uma variável importante para a formação da agenda das campanhas eleitorais. A partir dessa reelaboração do conceito da agenda-setting, os estudos deixaram de investigar apenas a influência da mídia no público, passando a analisar também a capacidade dos partidos políticos e candidatos influenciarem na formação da agenda dos meios de comunicação.

No Brasil, a agenda dos candidatos não foi incorporada aos trabalhos de mídia e política. Existe portanto uma escassez de trabalhos que tratam de averiguar se existe influência dos candidatos na agenda veiculada nos telejornais. Um dos meus objetivos nesse trabalho é tratar desta questão, demonstrando que, tal como foi constatado em outros países, a agenda da cobertura dos telejornais é influenciada pela agenda dos candidatos, especialmente mediante propaganda de televisão dos candidatos, e que, sendo assim, ela não deve ser desconsiderada, se desejamos ter uma visão mais ampla da formação da agenda dos noticiários na eleição presidencial de 2002.

Um outro objetivo é demonstrar que o PT, através de seu programa de governo, conseguiu influenciar a pauta da agenda da propaganda da candidatura Lula, e que, portanto, não deve ser excluído da análise da elaboração da agenda da propaganda de televisão na eleição referida. 
Capítulo 2

\section{Contexto da eleição presidencial de 2002}

\subsection{Introdução}

A eleição presidencial de 2002 confirmou mais uma vez que a democracia tem se consolidado no Brasil, o que o faz uma das grandes democracias do planeta. Nesta eleição, o candidato petista, Luiz Inácio Lula da Silva, elegeu-se Presidente da República, após três tentativas frustradas de galgar tal cargo. Embora Lula tenha obtido uma ampla margem de votos perante seus adversários no primeiro turno, não alcançou a maioria necessária para ser eleito. A vitória só ocorreria no segundo turno, quando obteve mais de 52 milhões de votos válidos, quantia aliás somente superada pelo republicano Ronald Reagan, na eleição presidencial norte-americana em 1984.

O sucesso eleitoral de Lula marcou o fim de oitos anos de governo do PSDB e também permitiu, pela primeira vez na história do país, que um candidato de esquerda chegasse à presidência.

Neste capítulo faço uma análise do contexto da disputa eleitoral presidencial de 2002, procurando destacar os aspectos mais relevantes que a influenciou, como a situação sócio-econômica pela qual o país atravessava no momento eleitoral, a articulação das alianças partidárias de sustentação das candidaturas e a campanha desenvolvida nos meios de comunicação.

\subsection{Aspecto da conjuntura sócio-econômica}

O final do segundo mandato de Fernando Henrique Cardoso foi marcado pelo baixo crescimento econômico, altas taxas de desemprego ${ }^{42}$ e pela percepção corrente de que muito pouco tinha sido feito para minorar o agudo e 
secular problema social brasileiro. Em função desse quadro, passou a predominar junto a amplos segmentos da população uma avaliação negativa do governo, conforme registros de pesquisas de opinião pública na época. Diferentemente da campanha de 1994 e da reeleição de Fernando Henrique em 1998, o controle inflacionário, obtido através do Plano Real, não ocupou, em 2002, o centro da preocupação da maioria do eleitorado brasileiro, que desejava mudanças.

Face ao quadro negativo associado ao governo FHC, Serra evitou identificar-se como candidato governista, apresentando-se também como alternativa de mudança. Buscou desvincular sua imagem do governo federal, mantendo o presidente Fernando Henrique distante de sua campanha, principalmente do horário eleitoral. Fez ainda crítica à política econômica vigente, principalmente quanto à política cambial e à de exportação ${ }^{43}$, afirmando categoricamente que seu governo não seria um terceiro mandato de FHC. Além disso, colocou-se como o candidato mais capaz de realizar as mudanças sociais e criar empregos no país, enfatizando suas realizações na área da saúde, durante a época em que foi ministro.

Essa estratégia de distanciamento de Fernando Henrique não impediu, no entanto, que Serra fosse visto, pela maior parte do eleitorado descontente, como candidato ligado ao governo federal. Por outro lado ao tentar se afastar do governo, evitando, assim, dar destaque às conquistas do Plano Real (como o sucesso no combate à inflação), a campanha pode ter contribuído para que Serra perdesse votos entre os eleitores que avaliavam bem o governo.

No que tange às propostas de campanha de Serra, um ponto que se destaca é a promessa de crescimento econômico de 4,5\% ao ano. Para o programa de governo tucano, o principal fator que limitava o crescimento era o déficit em conta corrente do balanço de pagamentos, em torno de $4 \%$ ao PIB,

\footnotetext{
${ }^{42}$ A taxa mensal de desemprego em julho de 2002 atingiu 8,27\%. Média em seis regiões metropolitanas de acordo com IBGE.

${ }^{43}$ Devemos lembrar que desde o lançamento do Real, Serra aprovava o plano com reservas, alegando a necessidade de reformas no sistema tributário, para garantir crescimento econômico. Foi aliás devido às suas críticas à política econômica que entrou em choque com
} 
equivalente a cerca de 40\% das exportações brasileiras. Esse déficit pressionava a taxa de juros para cima, freando os investimentos produtivos. Como solução, a plataforma defendia a necessidade de uma forte elevação do superávit comercial, capaz de diminuir o peso do déficit em conta corrente, através do aumento das exportações e manutenção do controle da inflação. Outro ponto fundamental da plataforma era a geração de 8 milhões de empregos, diretos e indiretos, que surgiriam em decorrência do crescimento da economia e de maiores investimentos do Estado na agricultura, indústria de construção e turismo. Na área social, a proposta era ampliação dos programas de saúde e educação, além da criação do Ministério da Segurança Pública.

No que se refere ao discurso das candidaturas de oposição - Luiz Inácio Lula da Silva, Ciro Gomes e Anthony Garotinho - todas elas adotaram a estratégia discursiva de desqualificação do governo FHC, responsabilizando-o pela estagnação econômica, desemprego, insegurança e pela crise social que assolava o país, e, em concomitância, cada qual se colocava como a mais capaz e competente para realizar as mudanças almejadas pela população.

O programa de governo de Lula ${ }^{44}$ tinha como centro o projeto de construção de um novo modelo de desenvolvimento para o Brasil, estruturado em duas dimensões: a social e a nacional. A primeira consistia na ampliação do nível de emprego, aumento do salário mínimo, melhoria da distribuição de renda e o combate à fome e à miséria. A segunda dimensão tinha como prioridade a capacitação tecnológica das empresas nacionais, privadas e públicas, e a ampliação das fontes de financiamento internas. Em síntese, o novo modelo promoveria a redistribuição de renda e diminuiria a excessiva dependência do país ao capital estrangeiro. Ao mesmo tempo, sua dinâmica impulsionaria a retomada do crescimento econômico, "instrumento essencial para a superação do círculo vicioso entre déficit externo, juros elevados, instabilidade cambial e aumento da dívida pública, criado pelo atual governo". Ao contrário do que defendia o programa de governo do $\mathrm{PT}^{45}$, que pregava a ruptura com a política

Gustavo Franco (então diretor de Assuntos internacionais do Banco Central) e Ciro Gomes (Ministro da Fazenda).

44 "Programa de Governo: Coligação Lula Presidente". Endereço eletrônico: <www.lula.org.br>.

${ }^{45}$ Ver discussão mais adiante. 
econômica de FHC, Lula admitia que a mudança deveria ocorrer de maneira responsável e confiável, isto é, sem colocar em risco o controle da inflação e admitindo o cumprimento de contratos assumidos pelo governo anterior.

A plataforma de governo da candidatura Ciro Gomes entendia que o modelo econômico, implantado a partir de 1995, tornou o país extremamente dependente de capitais externos e acarretou uma redução drástica do crescimento econômico. Para mudar esse quadro e o Brasil voltar a crescer, Ciro propunha um novo modelo econômico, baseado na geração de poupança interna, através de uma reforma tributária, reformulação do sistema de previdência e redução de juros. O combate ao desemprego também foi alvo do programa do candidato. Os empregos seriam criados em médio prazo, com o aumento da produção industrial, bem como a partir de medidas emergenciais como a construção de moradias populares, incentivo à agricultura e fim dos encargos sobre a folha salarial. O documento era a favor da manutenção da estabilidade da moeda, mas não concordava com o sistema de metas de inflação. Em relação à dívida externa, o candidato da Frente Trabalhista propunha um acordo com os credores para discutir melhores prazos e juros, sem quebras de contratos.

O programa de governo de Anthony Garotinho defendia a retomada do crescimento econômico com a manutenção da inflação sob controle e redução do desequilíbrio externo, que, por sua vez, seria obtida através das políticas de fomento às exportações e à substituição competitiva de importações e do incentivo à elevação da poupança interna. A geração de empregos, outro ponto crucial do documento de Garotinho, seria alcançada mediante o investimento na construção civil, turismo, agricultura e indústrias tradicionais como a têxtil e de calçados. Além da adoção dessas medidas para o combate ao desemprego, sua plataforma previa a adoção de programas compensatórios para amenizar a pobreza e o desemprego através da implantação de restaurantes populares e do "cheque-cidadania", no valor de $\mathrm{R} \$ 100$, para 1 milhão de famílias em estado de indigência. 
De maneira geral, para Luiz Inácio Lula da Silva, Ciro Gomes e Anthony Garotinho, a baixa avaliação do governo, decorrente da conjuntura sócioeconômica negativa, foi extremamente vantajosa, afinal forçava a opção por uma candidatura oposicionista. Dentre os três candidatos de oposição, Lula era o principal beneficiário em potencial, pois seu partido era o núcleo duro de oposição ao governo Fernando Henrique.

\subsection{Alianças partidárias}

O contexto da disputa eleitoral para presidente é também fortemente influenciado pelo processo de constituição de alianças eleitorais entre os partidos, recurso fundamental para aumentar as chances de vencer o pleito. A esse respeito, o pleito de 2002 diferiu bastante dos dois precedentes, dado que o PSDB não conseguiu reproduzir sua base de apoio que ajudou a eleger e reeleger Fernando Henrique. Dessa vez, nem o PTB nem o PFL aliaram-se aos tucanos. O PTB optou por dar apoio à candidatura de Ciro Gomes; e o PFL acabou por se desvincular de qualquer candidatura após uma série de desentendimentos com o PSDB. Mesmo quando a governadora do Maranhão, Roseana Sarney, ascendeu nas pesquisas de intenção de voto, no início de 2002, Serra ainda nutria esperança de que ela pudesse ser sua vice na disputa pela presidência. A chance de que isso viesse a acontecer desfez-se, no entanto, com o escândalo Lunus $^{46}$, cuja conseqüência foi a decisão do PFL, após consultar suas lideranças ${ }^{47}$, de não se aliar oficialmente a qualquer candidatura presidencial. Desse modo o PFL possibilitou que seus candidatos aos outros cargos pudessem realizar alianças variadas na esfera regional,

\footnotetext{
${ }^{46}$ Em primeiro de março de 2002, a Polícia Federal encontrou no escritório da empresa Lunus, que pertencia a Roseana e ao seu marido, 1,34 milhão de reais suspeitos de estarem vinculados a verbas desviadas da Superintendência do Desenvolvimento da Amazônia (SUDAM). Para maiores detalhes, consultar Veja, 13 de março de 2002.

${ }^{47}$ A maioria dos peefelistas entendeu que o partido não deveria apoiar nenhuma candidatura. $\mathrm{O}$ restante se dividia entre aqueles que admitiam o apoio a Ciro; os que queriam se aliar a Serra; e os que defendiam o lançamento de uma candidatura própria.
} 
somente permitidas, dada à chamada verticalização ${ }^{48}$, aos partidos que não se integrassem em uma aliança a nível nacional.

Mesmo não contando com o PFL, o PSDB conseguiu se aliar a um partido de peso - o PMDB. Mas não se tratou de uma aproximação tranqüila, produto como foi de um longo processo de negociação. Além da ameaça dos peemedebistas lançarem uma candidatura própria, algumas lideranças do partido, como o ex-presidente Itamar Franco (MG) e o ex-governador de São Paulo, Orestes Quércia (SP), que desejavam se juntar ao PT e lançar como vice de Lula o senador Pedro Simon (PMDB-RS), eram contrários a uma aliança com os tucanos. E mesmo após a concretização da aliança, tanto Itamar como Quércia declararam apoio à candidatura de Lula. Além disso, a definição de um vice do PMDB para compor a chapa com Serra, só se concretizou após duas tentativas frustradas. A primeira veio acontecer em março de 2002, com a indicação do governador de Pernambuco, Jarbas Vasconcelos, que recusou o convite, preferindo a reeleição ao governo de seu estado. A segunda tentativa foi a de lançar Henrique Eduardo Alves, deputado federal do Rio Grande do Norte. Essa opção também foi excluída, em face de denúncias veiculadas na imprensa de que Alves estaria envolvido com contas em paraísos fiscais ${ }^{49}$. Deste modo, a definição do vice e o selamento da aliança com o PMDB somente teve lugar no final de maio de 2002, com a escolha oficial da deputada federal do Espírito Santo, Rita Camata.

A candidatura Serra também enfrentou resistência no interior de seu próprio partido, com a relutância de alguns de seus líderes de lhe emprestar apoio. Entre eles destaca-se o caso do ex-governador do Ceará, Tasso Jereissati que, preterido na indicação partidária para a candidatura presidencial, fez abertamente campanha para Ciro Gomes em seu estado, o que lhe rendeu críticas de lideranças tucanas ${ }^{50}$. Aécio Neves, candidato ao

\footnotetext{
${ }^{48}$ De acordo com a verticalização das alianças exigia-se que a mesma aliança do plano federal fosse reproduzida nas eleições regionais.

${ }^{49}$ Segundo denúncias da Revista ISTOÉ.

50 Quando questionado pela imprensa se considerava a atitude de Tasso uma "apunhalada pelas costas", o presidente Fernando Henrique, demonstrando desapontamento para com o exgovernador, respondeu que se tratava de uma "apunhalada pela frente". Folha de São Paulo, 22 de agosto de 2002.
} 
governo mineiro, somente veio a fazer campanha para Serra após o presidente Fernando Henrique ter convocado uma reunião com os governadores e prefeitos do PSDB, no primeiro turno. Quando eleito governador, Aécio recusou-se a se manifestar abertamente contra a candidatura Lula no segundo turno, embora tenha colocado sua estrutura de campanha à disposição do candidato tucano.

Quem acabou sendo beneficiado por essas dificuldades enfrentadas pela candidatura Serra, foi Ciro Gomes. Com o fracasso da aliança do PFL com o PSDB, Ciro pôde contar com o auxílio de parte do PFL, representado pelo presidente do partido, Jorge Bornhausen, pela liderança baiana de Antônio Carlos Magalhães e pela ex-candidata Roseana Sarney, a qual tinha razões mais que suficientes para assumir franca oposição a Serra, objetivando que o mesmo não chegasse ao segundo turno. Ademais, a candidatura Ciro acabaria abarcando um outro ex-aliado dos tucanos, o PTB, além de contar com o apoio do PDT de Leonel Brizola.

Para o PT, o cenário político foi bem mais favorável. Além de reter seus antigos aliados ideológicos - o PC do $B$ e $P C B^{51}$ - e de incorporar partidos nanicos, como PMN, o PT obteve êxito na realização de seu projeto de se coligar com o PL, após superar a resistência da ala mais à esquerda ${ }^{52}$ do partido, contrária a qualquer aproximação com os liberais ${ }^{53}$. A partir da aliança com o PL, a candidatura Lula garantiu o apoio dos evangélicos, teve sua imagem melhorada junto aos empresários nacionais, uma vez que seu vice, o senador José de Alencar, era proprietário do maior grupo têxtil do Brasil, além de poder contar com a base eleitoral de Alencar em Minas Gerais, segundo maior colégio eleitoral brasileiro.

No primeiro turno, a candidatura petista trouxe para seu lado as lideranças descontentes do PMDB, as quais divergiam da aliança de seu

\footnotetext{
${ }^{51}$ Estes dois partidos de esquerda fazem parte das alianças históricas do PT.

52 Nos anos 90 foram criados dois blocos no partido: o bloco moderado ("Campo Majoritário"), que representa $70 \%$ dos filiados, e o bloco dos radicais que representa $30 \%$. Com José Dirceu na presidência da sigla em 1995, os moderados obtiveram o controle do partido.
} 
partido com o PSDB. Além de Quércia e Itamar, também teve assegurada a ajuda do ex-presidente José Sarney, que se mostrou disposto a retaliar o PSDB, por estar convencido, embora não houvesse nenhuma prova concreta, de que Serra havia sido o principal responsável pela implosão da précandidatura de sua filha ${ }^{54}$, Roseana. A adesão de tais figuras tradicionais da política brasileira, sem dúvida, ajudou a reforçar a imagem de moderação do discurso de Lula durante a campanha e, pari passu, mostrou que o candidato petista estava preocupado não apenas com a eleição mas também com a questão de apoios futuros no Congresso, caso fosse eleito.

No segundo turno, além dos peemedebistas insatisfeitos, Lula logrou agregar os dois principais candidatos derrotados - Ciro Gomes (PPS) e Anthony Garotinho ${ }^{55}$ (PSB). Como conseqüência, atraiu para seu lado a parcela do PFL que se juntou a Ciro Gomes no primeiro turno, com a exceção de Bornhausen.

No que tange à estratégia aliancista da candidatura de Garotinho, pelo PSB, restaram poucas alternativas de viabilização, restringindo-se à adesão oficial de dois partidos pequenos, o PGT e PTC, além da simpatia de parte do PPB. Ademais, ao longo da campanha, Garotinho enfrentou obstáculos dentro de seu próprio partido para manter sua candidatura, pois algumas lideranças defendiam a retirada de sua candidatura ${ }^{56}$, o que só não ocorreu graças à interferência de Miguel Arraes, presidente nacional do PSB. Diante da falta de apoios e uma grande restrição financeira, a campanha do peesebista limitou-se praticamente aos estados do Rio de Janeiro e São Paulo, não ganhando portanto caráter nacional.

\footnotetext{
${ }^{53}$ A senadora Heloísa Helena, na época, desistiu de concorrer ao governo de Alagoas, em virtude da não aceitação da aliança com o PL. Para maiores detalhes, consultar Veja, 23 de outubro de 2002, p. $42-44$.

${ }^{54} \mathrm{Em}$ seu discurso na tribuna do Senado, José Sarney denunciou a operação da Polícia Federal no escritório da Lunus como uma armação política e responsabilizou José Serra: "Há um fato cuja recorrência impressiona e intriga: é que toda a referência a este estilo característico de espionagem e dossiês, nasce no Ministério da Saúde, então sob a responsabilidade do Ministro José Serra". Folha de São Paulo, 21 de março de 2002.

${ }_{50}^{5}$ Parte do PSB optou por Serra.

56 Figura desconhecida do cenário da política nacional, sua base eleitoral era formada principalmente pela Igreja Universal e pelo eleitorado carioca, que havia aprovado seu governo de 1998-2002.
} 


\subsection{Campanha nos meios de comunicação}

No que se refere ao terceiro e último aspecto - a dinâmica da campanha no ambiente dos meios de comunicação - cabe examiná-lo tendo em conta duas fases em que se desenvolveu o processo eleitoral: o período pré-eleitoral, ou seja, aquele que precedeu o início oficial do processo; e o período eleitoral, iniciado com o lançamento oficial das candidaturas e que persistiu até à véspera do final da eleição no segundo turno.

O período pré-eleitoral, o qual se iniciou no final de 2001 e se estendeu até o começo de julho de 2002, teve como evento mais significativo as apresentações dos programas partidários de rádio e televisão ${ }^{57}$, anualmente disponibilizadas por lei a todos os partidos políticos. Tratou-se de uma fase importante para a visibilidade dos candidatos, haja vista que, cada vez que uma candidatura aparecia na televisão, as pesquisas registravam um aumento da sua intenção de voto.

A pré-candidata Roseana Sarney foi um bom exemplo disso. No final de 2001 e início de 2002, sua exposição pela televisão através dos programas partidários do PFL rendeu-lhe grande visibilidade. A estratégia explorada, a partir da ênfase na avaliação positiva do governo de Roseana no Maranhão e na importância da valorização da mulher no Brasil, parece ter surtido efeito, uma vez que depois de exibidos os programas, a pré-candidata atingiu $18 \%$ nas pesquisas de intenção de voto, ocupando a segunda posição (ver GRAF. 2.1). Contudo, após o caso Lunus, em março, Roseana começou a declinar nas pesquisas, o que acabou culminando na sua desistência de disputar a eleição presidencial.

GRÁFICO 2.1- Intenção de voto para presidente eleição presidencial de 2002

57 Paralelamente aos p pré-campanha.

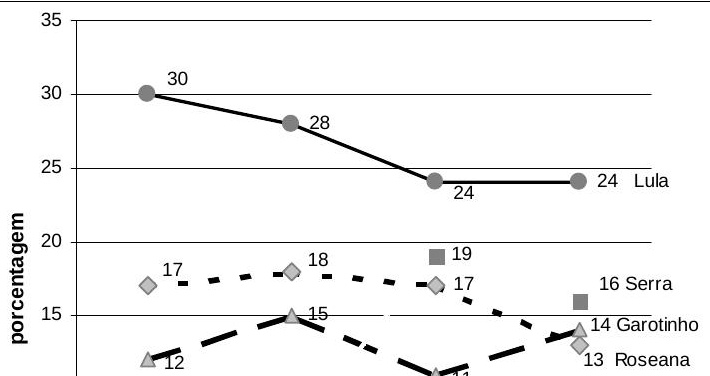


Fonte: Ibope.

Nota. Foram excluídas as categorias de votos brancos/ nulos e não sabe.

O candidato Luiz Inácio Lula da Silva também teve uma ascensão nas pesquisas de intenção de voto, num momento posterior à apresentação dos programas do PT na televisão. Essa ascendência nos testes de opinião pública foi seguida por uma alta do dólar, queda da bolsa de valores e aumento do Risco-Brasil, índice que mede a desconfiança do negociante estrangeiro para investir no país, que se aproximou de mil pontos, em 17 de maio, após Lula ter alcançado $42 \%$ nas pesquisas, em 13 de maio, como podemos observar nos gráficos abaixo.

GRÁFICO 2.2 - Intenção de voto em Lula no período de março a maio de 2002

Intenção de voto em Lula (\%)

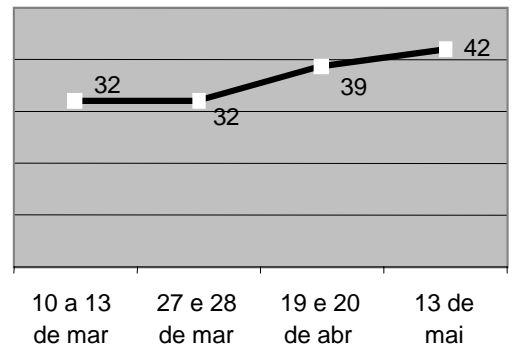


GRÁFICO 2.3 - Variação do risco Brasil no período de março a maio de 2002

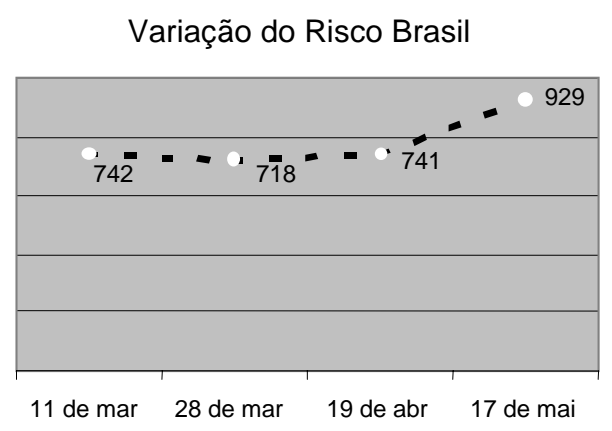

Fonte: J.P Morgan.

Tal ambiente de crise no campo econômico deveu-se, em grande parte, à expectativa negativa por parte dos investidores estrangeiros quanto à possibilidade de que os acordos e contratos existentes ${ }^{58}$ no país fossem honrados por Lula, uma vez que o documento petista, "Concepção e diretrizes do programa de governo do PT para o Brasil" - formulado no encontro partidário nacional em dezembro de 2001 e publicado no site oficial do

\footnotetext{
${ }^{58}$ Os bancos norte-americanos Morgan Stanley e Merrill Lynch recomendaram aos investidores internacionais que diminuíssem o volume de papéis brasileiros de suas aplicações, apontando como fator de preocupação o ótimo desempenho de Lula nas pesquisas. Veja, 22 de maio de 2002.
} 
partido ${ }^{59}$, em março de 2002 - defendia uma ruptura efetiva com o modelo econômico vigente:

Para quem defende, não uma mera "continuidade sem continuísmo", pela adoção de uma política "desenvolvimentista" que agrega o "social" como acessório, mas uma verdadeira transformação inspirada nos ideais éticos da radicalização da democracia e do aprofundamento da justiça social, não pode restar dúvida de que um governo democrático e popular precisará operar uma efetiva ruptura global com o modelo existente, estabelecendo as bases para a implementação de um modelo de desenvolvimento alternativo.

Diante desse clima de tensão, Lula, numa tentativa de acalmar o mercado, divulgou em 22 de junho de 2002, um documento intitulado "Carta ao Povo Brasileiro" 60 , no qual mostrava que a alteração do modelo econômico proposta seria feita com a manutenção do superávit primário e controle da inflação: "Quero agora reafirmar esse compromisso histórico com o combate à inflação, mas acompanhado de crescimento econômico e geração de empregos". Salientava também que a mudança considerava uma fase de transição na qual seriam respeitados todos os acordos realizados pelo governo anterior: "premissa dessa transição será naturalmente o respeito aos contratos e obrigações do país".

Assim como Roseana e Lula, o candidato da Frente Trabalhista - Ciro Gomes - teve uma ascensão nos prognósticos eleitorais após a apresentação dos programas partidários na televisão. Utilizando-se dos espaços de televisão do PTB e do PDT, partidos oficialmente coligados ao PPS, Ciro Gomes mostrou ao eleitor que era o candidato ideal para promover as mudanças na área econômica e social. Ademais, contou com o apoio de sua mulher, a atriz Patrícia Pillar, que falou em seu nome no programa do PDT. Após a veiculação dos programas, as pesquisas de intenção de voto, realizadas no final de julho de 2002, mostraram que o candidato havia passado de $20 \%$, no início de julho,

\footnotetext{
59 Endereço eletrônico <www.pt.org.br>.

${ }^{60}$ Em 23 de julho o candidato divulgou um outro documento, "Compromisso com a Soberania, o Emprego e a Segurança do Povo Brasileiro", com a mesma intenção.
} 
para 28\% na intenção de voto (ver gráfico abaixo). A esta altura, tais pesquisas ainda indicavam que somente Ciro seria capaz de vencer Lula no segundo turno.

GRÁFICO 2.4 - Intenção de voto para Presidente - primeiro turno da eleição presidencial de 2002

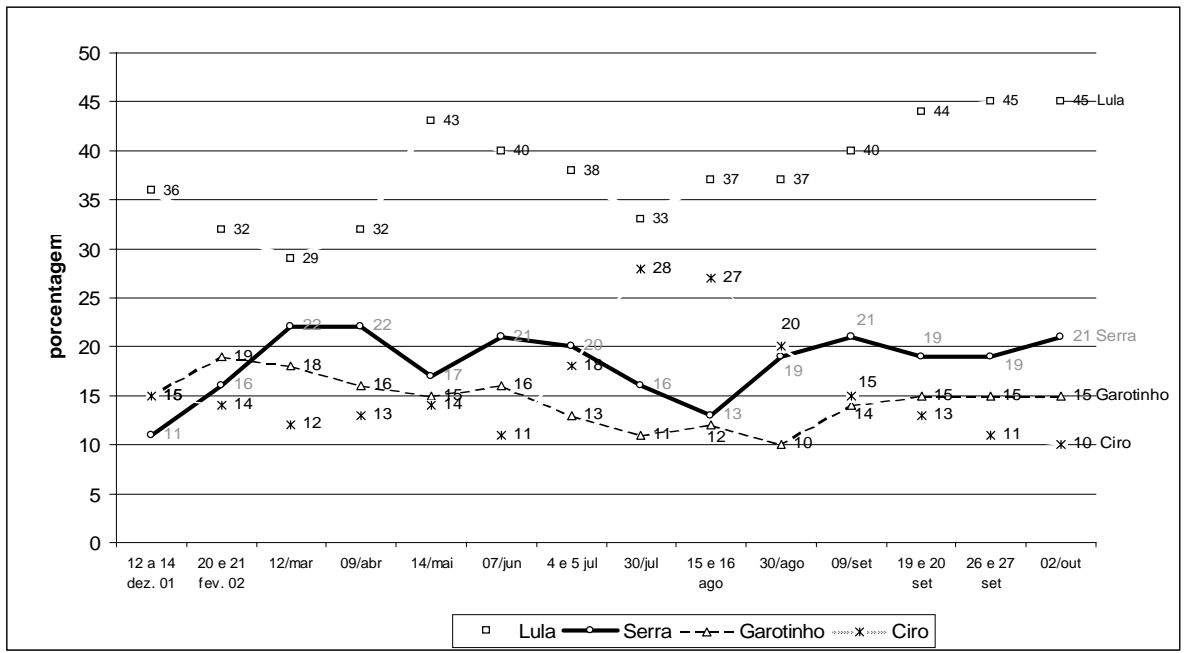

Fonte: Datafolha.

Nota. Foram excluídos os porcentuais de José Maria e de Rui Pimenta e as categorias de votos brancos/ nulos e não sabe.

O segundo período da campanha, iniciado a partir de 5 de julho, após a aprovação das candidaturas pelas convenções, e que se estendeu até o fim do segundo turno da eleição, constituiu-se do acompanhamento das candidaturas realizado pela mídia radiofônica, impressa e Internet, além da campanha eleitoral na televisão, através das entrevistas com os candidatos em programas jornalísticos, debates, cobertura eleitoral diária dos noticiários e é claro, pelo horário gratuito e spots de televisão.

Os debates e entrevistas de tevê, em especial, tornaram-se uma boa vitrine para os candidatos. Depois de serem pouco utilizados na eleição de 1998 (somente para governador), os debates entre os presidenciáveis se destacaram na cena eleitoral em 2002, ampliando, assim, a discussão política 
da campanha. Ao todo, foram quatro debates promovidos pelas redes de tevê, um na Bandeirantes, outro na Record e dois na Globo ${ }^{61}$. Quanto às entrevistas com os candidatos, tratou-se de uma inovação. As emissoras Globo ${ }^{62}$, Bandeirantes, Record, Cultura, SBT, RedeTeve e GloboNews, realizaram, ao todo, 63 entrevistas em programas jornalísticos com os presidenciáveis ${ }^{63}$.

Em relação à cobertura presidencial nos telejornais, só o Jornal Nacional, noticiário de maior audiência do país, destinou 17 horas, 18 minutos e 8 segundos no período relativo ao primeiro e o segundo turno ${ }^{64}$ (entre $1^{\circ}$. de julho e 26 de outubro). Já o Jornal da Record gastou, com a cobertura da eleição presidencial, 18 horas, 14 minutos e 16 segundos $^{65}$, durante o mesmo período.

O horário eleitoral de tevê e inserções comerciais de 30 e 60 segundos $^{66}$ iniciou-se em 20 de agosto de 2002. De modo geral, a propaganda eleitoral de televisão foi o espaço mais importante para os políticos se comunicarem com os eleitores nessa fase.

A estratégia de comunicação predominante no horário eleitoral gratuito, adotada pelas quatro principais candidaturas, foi a apresentação de seus programas de governo. Em particular, de maneira paralela às propostas, 0

\footnotetext{
61 No segundo turno a Rede Globo inaugurou o estilo de debate de arena, como nos Estados Unidos, no qual os candidatos não fazem perguntas um ao outro, apenas respondem, em pé, às indagações dos jornalistas e das pessoas do auditório. Sobre o assunto, consultar FAUSTO NETTO, O Corpo Entre Capturas e Fugas Enunciativas, in Fausto Neto, Verón (orgs.) Lula Presidente - televisão e política na campanha eleitoral, Unisinos, 2003, pp. 147-174.

${ }^{62}$ Só na Globo foram realizadas entrevistas com os candidatos no Jornal Nacional, Jornal da Globo e Bom Dia Brasil.

${ }^{63}$ De acordo com pesquisa efetuada pela revista Época, 28 de outubro de 2002.

${ }^{64}$ Foram considerados os tempos de todas as matérias que envolveram as candidaturas dos seis candidatos à presidência. SILVA, Paulo Sérgio da. "A Cobertura Eleitoral do Jornal Nacional na Eleição Presidencial de 2002", texto apresentado no Workshop: "Partidos e Representação Política", Departamento de Ciência Política da Universidade de São Paulo, 21 de agosto de 2003.

${ }^{65}$ Idem.

${ }^{66} \mathrm{O}$ horário eleitoral gratuito do primeiro turno terminou no dia 3 de outubro. Por dia, dois programas foram levados ao ar, um no período da tarde (das 13h às 13h 25) e um na parte da noite (das $20 \mathrm{~h} 30$ às 20h 55). Os programas foram exibidos às terças, quintas e sábados durante a semana. Além de aparecer no horário eleitoral de tevê, os candidatos tiveram uma cota diária de tempo para inserções comerciais durante a programação diária das emissoras. No segundo turno, o horário eleitoral se estendeu do dia 14 a 25 de outubro de 2002, de segunda a domingo, no mesmo horário do primeiro turno. O tempo destinado a cada programa do horário eleitoral dos candidatos, foi de 10 minutos.
} 
candidato Serra, juntamente com sua equipe de campanha ${ }^{67}$, também fez uso da tática da propaganda negativa. Aproveitou as declarações polêmicas do candidato Ciro Gomes, divulgadas na imprensa (tais como aquela em que chamou um eleitor de "burro"), para mostrá-lo, no horário eleitoral de tevê, como uma pessoa despreparada. Após os ataques desferidos contra o candidato Ciro, as pesquisas, no início de setembro, apontaram uma ascensão de Serra e uma queda brusca da candidatura da Frente Trabalhista (ver GRAF. 2.4).

Enquanto a propaganda de Serra na televisão tinha como alvo os ataques a Ciro, a candidatura de Anthony Garotinho subia nas pesquisas de intenção de voto, passando de 10\%, em agosto, para 15\%, no início de setembro, índice que manteve até o final do primeiro turno. Preocupado com a evolução de Garotinho nas pesquisas, o candidato tucano passou a atacá-lo na tevê, acusando-o de ser o principal responsável pelo aumento da violência no estado do Rio.

Serra repetiu a estratégia de campanha negativa contra Lula, tanto no primeiro como no segundo turno. Os ataques na tevê chegaram a afirmar que Lula não tinha preparo e nem competência para administrar o país, pelo fato dele não ter diploma superior; colocaram em dúvida a viabilidade do programa de governo de Lula, através do bordão: "Lula, ou ele esconde o que pensa ou ele não sabe o que diz"; semearam o medo de que Lula ameaçasse a governabilidade e levasse o Brasil a uma crise parecida com a que estava ocorrendo na Argentina; além do mais, associaram o PT ao "lobo em pele de cordeiro", ou seja, insinuaram que o partido divulgado na propaganda, "um PT bem maquiado, bonzinho, equilibrado", mascarava, "o verdadeiro PT, radical, das greves e do MST".

No entanto, se Serra foi bem sucedido com seus ataques direcionados a Ciro, o mesmo não se repetiu com a utilização dessa mesma estratégia contra

\footnotetext{
${ }^{67}$ O publicitário Nizan Guanaes, responsável pelas campanhas bem sucedidas de Fernando Henrique, foi o chefe da propaganda de televisão e rádio da candidatura Serra durante o primeiro turno. No segundo turno, porém, Nizan deixou a campanha e quem assumiu o cargo foi Nelson Biondi, profissional que já havia feito campanhas publicitárias para o candidato.
} 
Lula. Como podemos notar no GRAF. 2.4, Lula teve um aumento da intenção de voto no período em que houve os ataques de Serra na tevê, entre a segunda quinzena de setembro e o final do primeiro turno, enquanto Serra estagnou nas pesquisas, com 19\%. No segundo turno, Lula manteve-se na dianteira das pesquisas, com uma ampla vantagem sobre o candidato governista, ou seja, com uma diferença média de 30 pontos percentuais à frente de Serra, como ilustra o GRAF. 2.5.

GRÁFICO 2.5 - Intenção de voto para presidente - segundo turno da eleição presidencial de 2002

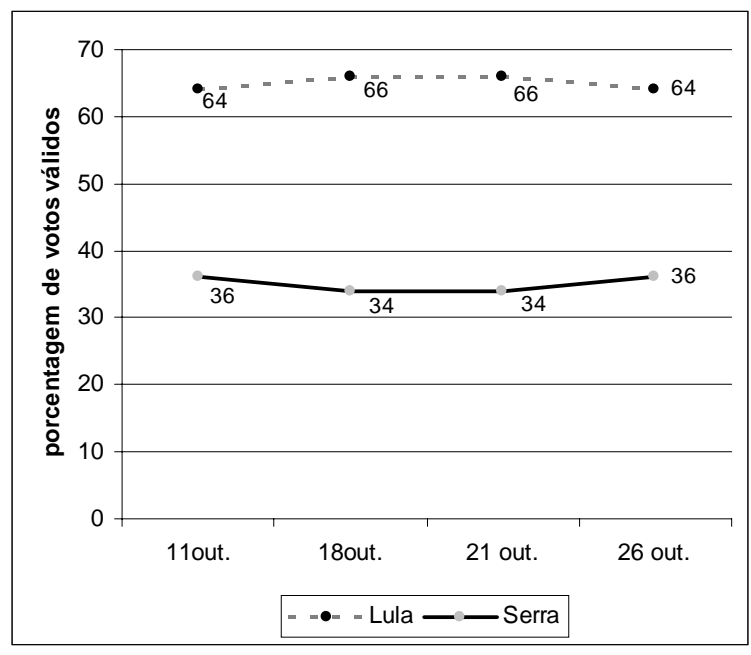

Fonte: Datafolha.

Dentre outros fatores que contribuíram para a neutralização da política negativa anti-Lula, levada a cabo na propaganda de Serra na televisão, as declarações do Presidente da República na imprensa, embora involuntariamente, tiveram um peso relevante. As afirmações de Fernando Henrique de que não era necessário ter diploma universitário para ser presidente de uma nação e de que não existia uma "onda vermelha" no país, 
mas sim um "jogo democrático"68, foi na contramão do que tentava passar a candidatura tucana, afinal, aquele que deveria ser o principal defensor, desaprovava ataques de Serra contra Lula.

Frente aos ataques de Serra, a propaganda do candidato petista não tratava de revidar, evitando assim macular a imagem de Lula como conciliador, calmo, tranqüilo e sensível, que se estava construindo. Outrossim, estudos internacionais mostram que a estratégia de ataques é usada quando a disputa entre os concorrentes é acirrada. Na medida em que Lula estava em posição bem acima de seus concorrentes, não precisou utilizar-se de ataques, embora por isso mesmo fosse alvo preferencial.

Ao invés de uma campanha agressiva, a propaganda de Lula na televisão fez surgir perante as câmeras um candidato, como disse Fausto Neto, “através de um formato 'zen', em que Lula conversa com o eleitor, não interpela, confidencia, pede, não ordena"69. Diferentemente do marketing de campanhas presidenciais anteriores, em que Lula era apresentado como um político radical, a estratégia do publicitário Duda Mendonça, chefe da comunicação da campanha petista, foi passar a imagem de um candidato hábil em dialogar com os mais variados grupos de interesses da sociedade e em apontar soluções para os problemas. O foco dado nos filhos de Lula e na esposa, Marisa, procurou mostrar que Lula não era apenas um político, mas um candidato que tinha uma família e era uma pessoa igual às outras. Tais ingredientes, associados a outros não lembrados aqui, ajudaram na reconstrução da imagem do candidato petista, a qual recebeu uma espécie de codinome, "Lulinha paz e amor", que acabou se tornando a marca registrada da campanha.

\subsection{Conclusões}

\footnotetext{
${ }^{68}$ Folha de São Paulo, 15 de outubro de 2002.

69 FAUSTO NETO, Entre os Cruzamentos dos Sentidos, in Fausto Neto, Verón (orgs.) Lula Presidente - televisão e política na campanha eleitoral, Unisinos , 2003, p. 74.
} 
Neste capítulo, procurei destacar que são estes três aspectos, a conjuntura sócio-econômica, a articulação das alianças partidárias de sustentação das candidaturas e o contexto da campanha na televisão, o "pano de fundo" da análise sobre a relação da campanha e cobertura da mídia que realizarei nos próximos capítulos. 
Capítulo 3

\section{Conteúdo das agendas em jogo}

\subsection{Introdução}

O que o PT e o candidato José Serra defendiam em seus programas de governo? Quais as propostas e qualidades pessoais divulgadas por Lula e Serra no horário eleitoral de televisão e spots? Quais os enfoques dados pelo Jornal Nacional e Jornal da Record nas coberturas de Lula e Serra?

Neste capítulo, procuro dar resposta a estas questões através do exame do conteúdo dos programas de governo, da propaganda dos candidatos na televisão e da cobertura eleitoral dos telejornais na eleição presidencial de 2002. O capítulo está dividido em três partes. Na primeira, procuro mostrar os pontos básicos dos programas de governo do PT e de Serra, além de fazer o levantamento quantitativo dos assuntos de cada uma destas plataformas. $\mathrm{Na}$ segunda, examino a propaganda de Lula e a de Serra, demonstrando como as propostas, qualidades pessoais e ataques foram veiculados, bem como quais assuntos receberam mais destaque na propaganda. Na terceira, analiso a maneira como o Jornal Nacional e Jornal da Record conduziram a cobertura de Lula e de Serra, e, em seguida, apresento as porcentagens de todos os assuntos da cobertura de ambos telejornais sobre cada uma dessas candidaturas em particular. As categorias de assuntos usadas para a análise quantitativa deste capítulo são aquelas anteriormente apresentadas no primeiro capítulo deste trabalho. 


\subsection{Programas de governo}

\section{O programa do $P T$}

O programa de governo do $\mathrm{PT}^{70}$ estava dividido em duas seções. Numa primeira, denominada "A ruptura necessária", apresentava um diagnóstico sócio-econômico do país, de modo sucinto, e em seguida, justificava os motivos da necessidade da ruptura com o atual modelo econômico e a implantação de um alternativo. Numa segunda parte, intitulada "As bases de um programa democrático popular para o Brasil", exibia, detalhadamente, as diversas faces do novo modelo proposto e seus eixos de sustentação.

A análise da conjuntura brasileira, elaborada pelo programa, assinalava que nos anos 90 havia ocorrido uma reação conservadora neoliberal, fundamentada na concepção do "Estado mínimo" e do mercado auto-regulador, que acarretava, para o país, um conjunto de conseqüências negativas. No plano social, a política econômica neoliberal, seguida pelos governos Collor e, depois, radicalizada nos dois mandatos da administração de Fernando Henrique Cardoso (1994-1998/ 1998-2002), era apontada, pela plataforma petista, como responsável pelo enorme descaso pelo social, acirramento da concentração de renda e ampliação da pobreza e miséria. Na esfera econômica, esse modelo, ancorado na dependência do capital estrangeiro e numa vasta abertura comercial, provocava a vulnerabilidade da economia do país, estagnação do crescimento econômico, altas taxas de desemprego e juros elevados.

\footnotetext{
${ }^{70} \mathrm{O}$ documento que utilizo para esta descrição é aquele divulgado no site oficial do partido (<www.pt.org.br >), "Concepção e Diretrizes do Programa de Governo do PT para o Brasil", em março de 2002, resultante do Encontro nacional do PT, ocorrido em dezembro de 2001.
} 
Diante da condição retratada, o programa defendia a necessidade da adoção de um novo modelo de desenvolvimento, o qual deveria tornar como base essencial, três dimensões: a social, a nacional e a democrática.

Para a inclusão do social no eixo do desenvolvimento era necessário a revalorização dos aspectos sociais, como educação, saúde, saneamento básico, habitação, cultura e o combate à fome. Mas apenas esses aspectos não seriam suficientes para o alcance dessa meta:

Por um lado, será necessário incidir sobre fatores estruturais que determinam os padrões de apropriação e distribuição da renda e da riqueza, como as relações da propriedade da terra e do capital, as relações de trabalho, as modalidades de organização e de integração dinâmica do sistema produtivo, o caráter do Estado e suas conseqüências na tributação e no uso dos recursos públicos. Por outro, a materialização de mudanças na estrutura de distribuição de renda e riqueza só será possível se as medidas redistributivas adotadas forem acompanhadas por transformações na produção e no investimento que as orientam para um amplo mercado de consumo essencial de massas.

A dimensão nacional, por sua vez, se tornaria o eixo do desenvolvimento mediante a inserção soberana do Brasil no mundo e a recuperação dos espaços de autonomia na economia nacional. Isso implicaria desenvolver políticas para reduzir a dependência e a vulnerabilidade externas, que constituíam num obstáculo para a retomada e sustentação do crescimento econômico e geração de empregos. De acordo com o programa, para se atingir esse objetivo, algumas políticas específicas, num contexto macro-estrutural, deveriam ser implantadas no país. Podemos resumi-las conforme se segue:

- recuperar o saldo comercial e reduzir o déficit na conta de serviços do balanço de pagamentos;

- corrigir os desequilíbrios oriundos da abertura comercial, através da revisão da estrutura tarifária e da criação de proteção não-tarifária; 
- adequar a política relativa ao capital estrangeiro às diretrizes e às prioridades do novo modelo;

- regular o processo de abertura do setor financeiro;

- denunciar (sic), do ponto de vista político e jurídico, o acordo com FMI, para liberar a política econômica das restrições impostas ao crescimento e à defesa comercial do país e bloquear as tentativas de re-estatização da dívida externa, reduzindo a emissão de títulos da dívida interna indexados ao dólar;

- consolidar a vocação de multilateridade do comércio exterior brasileiro mediante políticas direcionadas à diversificação de mercados, ao fortalecimento do Mercosul, ao estabelecimento do programa de cooperação econômica e tecnológica com potências emergentes como a Índia, China e África do Sul.

Finalmente, em relação à última dimensão, a democrática, a proposta era o estabelecimento de um novo contrato social, no qual, a construção de um novo modelo fosse instituída a partir do Estado de Direito e no permanente diálogo com a participação democrática e não da maneira como as " 'coalizões políticas' dominantes até então haviam administrado o país, sustentada na dependência externa e, internamente, fechada sobre si mesma, de forma autocrática e não democrática". Para tal proposta vir a se concretizar tornava-se necessário uma ampla reforma política.

No campo da educação, a proposta central era universalizar o ensino básico e reduzir a evasão escolar, tendo como preocupação a sua qualidade. Para alcançar essa meta, o governo deveria reverter o processo de municipalização da escola pública e estabelecer um novo marco de solidariedade entre os entes federativos para assegurar a garantia de universalização da educação básica e recuperar a qualidade do ensino em todos os níveis.

Havia também, no programa, uma grande preocupação com a valorização da cultura nacional, entendendo que ela era fundamental para o 
resgate da identidade do país. Nesse sentido, era preciso realizar um amplo processo de inclusão social e cultural:

Garantindo de forma progressiva, o acesso de toda a cidadania à produção e fruição cultural, bem como a livre circulação de idéias e de formas de expressão artística. De modo análogo, é importante fomentar a formação e a prática de esporte e lazer, como contribuição à melhoria da qualidade de vida no país.

Como se pode observar pelo sumário apresentado, o programa do PT propôs uma grande ruptura com o modelo econômico em vigor implantando um caminho de desenvolvimento alternativo. Tratava-se, pois, de um projeto claramente de esquerda, com ênfase, de um lado, na defesa de um Estado forte, capaz de planejar e promover o desenvolvimento econômico da nação e empregos e de gerar políticas públicas de redistribuição de renda e combate à exclusão social; e, de, outro, na rejeição à concepção do "estado mínimo" na economia, aos acordos com o Fundo Monetário Internacional (FMI) e às privatizações das empresas estatais.

A tabela a seguir, resultante do cálculo das porcentagens das menções das categorias de assuntos do programa de governo do PT, ilustra que a economia $(60,43 \%)$ centralizou a maior parte da discussão no documento.

TABELA 3.1 - Assuntos substantivos do programa de governo do $\mathrm{PT}$ - em porcentagem

\begin{tabular}{lcc}
\hline Categorias de assuntos & $(\%)$ & ordem \\
\hline economia & 60,43 & 1 \\
social em geral & 12,44 & 2 \\
educação & 3,79 & 3 \\
fome & 2,73 & 6 \\
saúde & 1,3 & 9 \\
infra-estrutura & 2,96 & 5 \\
cultura/lazer/etnia & 3,08 & 4 \\
segurança & 2,13 & 7 \\
meio-ambiente & 1,18 & 10 \\
assuntos estrangeiros & 1,07 & 11 \\
regiões brasileiras & 1,9 & 8 \\
cidades & 0,71 & 12 \\
outros & 6,28 & \\
\hline Total $\quad\left(n=844^{*}\right)$ & 100 & \\
\hline
\end{tabular}


* $N$ é o total de menções de todas as categorias.

A preponderância do fator econômico no programa do PT para a candidatura presidencial pode ser compreendida pelo fato do projeto do PT ter tomado como principal meta a construção de um novo modelo de desenvolvimento. Como esse modelo alternativo dependia, em grande parte, de transformações na área da economia, os temas sobre esse assunto sobressaíram-se mais na agenda do partido.

Já o assunto social em geral (12,44\%) também foi consideravelmente destacado no programa, já que o projeto era tornar a dimensão social um dos eixos "estruturantes" do novo modelo de desenvolvimento proposto. Os assuntos específicos da área social, ou seja, educação, saúde, segurança e fome também receberam atenção considerável na plataforma do PT (ver TAB. 3.1).

\section{O programa de José Serra}

Lançado no início de agosto de 2002, o programa de Serra ${ }^{71}$ era subdivido em dez tópicos e bem mais extenso do que a plataforma apresentada pelo PT, em março do mesmo ano.

Primeiramente, o programa fazia uma breve análise da conjuntura brasileira da década de 90, compreendendo que, embora o governo de Fernando Henrique Cardoso tivesse produzido importantes avanços na área social e conseguido vencer a superinflação, que atingia $80 \%$ ao mês, o país ainda apresentava graves problemas, como o alto nível de desemprego, reduzidas taxas de crescimento econômico, aumento da violência nas capitais e grandes desigualdades sociais. Porém, em sentido inverso ao programa do PT, que culpava o modelo econômico em vigência, pelo agravamento desses 
aspectos citados anteriormente, o programa de Serra sustentava serem as injustiças da sociedade brasileira seculares cujas causas não poderiam ser eliminadas em apenas 8 anos. Quanto ao fraco crescimento da economia e à situação do desemprego existente, o programa entendia que era reflexo, em grande parte, de crises econômicas mundiais, embora admitisse que alguns desajustes da política econômica do atual governo tivessem um peso relativo.

Tomando a questão do desemprego como a principal preocupação de seu programa, Serra apresentou um projeto para a geração de 8 milhões de postos de trabalho. Dessa quantia, 2 milhões 320 mil seriam obtidos com uma taxa de crescimento econômico de 4,5\%, em média, entre 2003 e 2006, através da redução de juros, incentivo à exportação, valorização da indústria brasileira e criação de mais facilidades de investimentos e apoio às pequenas e médias empresas. O restante dos empregos seria gerado como resultado do investimento do governo nos setores que criam mais oportunidades: 3 milhões na agropecuária, através da expansão do Programa Nacional da Agricultura Familiar (PRONAF) e da criação do Fundo de Aval; 850 mil no turismo, com o aumento de 5 milhões para 9 milhões de turistas estrangeiros e a expansão do turismo doméstico; 600 mil na construção civil; 500 mil na saúde, ampliando programas como o Saúde da Família e o da Saúde Bucal e investindo em modernização da infra-estrutura do Sistema Único de Saúde (SUS) e saneamento básico; 730 mil empregos na educação, criando novas creches para crianças de 0 a 3 anos, colocando as crianças de 4 a 7 anos na escola, aumentando o tempo de permanência na escola para 20\% das crianças do ensino fundamental e abrindo novas vagas para o ensino médio, além de aumentar em pelo menos $50 \%$ as vagas do ensino profissional e ensino superior até 2006.

Para a área da segurança, previa-se a criação do Ministério da Segurança Pública, que teria como órgãos subordinados a Polícia Federal e a Polícia Rodoviária Federal, para combater o crime organizado. Além disso, o projeto previa o aumento dos profissionais de 8.000 para 20.000; e a revisão

71 "Trabalho e Progresso Para Todos". Endereço Eletrônico:<www.joseserra.com.br>. 
dos Códigos Penal e de Processo Penal, bem como da lei de Execuções Penais.

No campo da infra-estrutura as medidas objetivavam o investimento em programas de saneamento básico e habitação. Para os municípios, as propostas, de maneira resumida, eram: ampliar o Fundo do Desenvolvimento do Ensino Fundamental (FUNDEF), para atender a educação infantil e o ensino médio; garantir a continuidade do "Programa Dinheiro Direto na Escola", fortalecendo a economia da administração escolar dos municípios; criar a "lei do leite", tornando o leite obrigatório na merenda escolar.

Três regiões brasileiras foram bastante lembradas pelo programa de governo: o Nordeste, Minas Gerais e a região da Amazônia. Para os nordestinos, Serra prometia ampliar as realizações na área social, saúde e educação, criar a ferrovia Transnordestina e reativar a SUDENE (Superintendência do Desenvolvimento do Nordeste). Dentre as promessas para os mineiros, estavam: investimento de 1 bilhão de reais na recuperação e duplicação de rodovias; investimento em transporte ferroviário e na construção de aeroportos; revitalização da cafeicultura no estado; e maior segurança aos turistas na região. Para a Amazônia, as medidas previam a criação de um ministério especial para a região e uma política de desenvolvimento específica.

De forma geral, o programa de governo tucano tinha como alvo principal a realização da mudança, principalmente na área econômica, através da promessa da geração de empregos. A maneira de alcançá-la, distintamente da defendida pelo programa petista, de ruptura estrutural com o modelo econômico implantado no governo de Fernando Henrique, era promover alguns ajustes na política econômica, que possibilitasse crescimento sustentável e geração de empregos sem determinar o rompimento com o FMI. Nesses termos, o programa de Serra apresentava-se como mais moderado do que o do PT, o primeiro defendendo "continuidade sem continuísmo", e o segundo, mais à esquerda, defendia "mudança sem continuidade".

Quanto à quantificação do programa de Serra, podemos notar na TAB. 3.2 que o foco do documento também se voltou para a discussão do assunto 
economia $(47,87 \%)$, embora em proporção bem menor do que o programa petista.

TABELA 3.2 - Assuntos substantivos do programa de governo de Serra - em porcentagem

\begin{tabular}{lcc}
\hline Categorias de assuntos & $(\%)$ & ordem \\
\hline economia & 47,87 & 1 \\
social em geral & 9,85 & 2 \\
educação & 8,58 & 3 \\
fome & 0,95 & 11 \\
saúde & 4,39 & 6 \\
infra-estrutura & 6,17 & 5 \\
cultura/lazer/etnia & 1,52 & 9 \\
segurança & 6,55 & 4 \\
meio-ambiente & 3,12 & 7 \\
assuntos estrangeiros & 0,7 & 13 \\
regiões brasileiras & 1,59 & 8 \\
cidades & 1,08 & 10 \\
Forças Armadas & 0,89 & 12 \\
outros & 6,74 & \\
\hline Total (n=1573*) & 100 & \\
\hline
\end{tabular}

* $N$ é o total de menções de todas as categorias.

A questão social em geral (9,85\%), ou seja, todas as vezes que a propaganda do candidato se referiu ao termo social de modo abrangente, também foi frisada no programa. De modo um pouco diferente do programa do PT, as questões sociais específicas, como educação (8,58\%), segurança $(6,55 \%)$ e saúde $(4,39 \%)$ receberam mais atenção no programa de Serra. Isso ocorreu em virtude do maior detalhamento, imprimido por seu programa, das políticas para as áreas específicas do âmbito social.

\subsection{Propaganda de Lula e de Serra na televisão}

\section{A propaganda de Lula}

A propaganda de Luiz Inácio Lula da Silva na televisão caracterizou-se pela apresentação minuciosa de propostas de programa de governo e também pelas críticas à administração de Fernando Henrique Cardoso. Além disso, enfatizou as qualidades pessoais de Lula e fez apelos de esperança e mudança. 
A crise econômica ocorrida a partir de junho de 2002 era, segundo a propaganda do candidato petista, um sinal claro do esgotamento do modelo econômico da administração vigente. Ou seja, segundo a propaganda petista os investidores internacionais estavam preocupados, não com a ascensão de Lula nas pesquisas, mas com a possibilidade do governo FHC não conseguir honrar suas dívidas, diante do enfraquecimento das exportações brasileiras e da baixa captação de dólares.

$\mathrm{Na}$ avaliação do candidato Lula no horário eleitoral de televisão, o governo FHC era o principal culpado pela crise em que estávamos imersos: "Ao invés de ter investido pesado na produção, geração de empregos, o governo atual optou pelo endividamento externo, expondo o Brasil à especulação financeira, é por isso", seguia o candidato, "que falta dinheiro para projetos sociais, investimento em infra-estrutura, salário mínimo e moradia popular".

De forma semelhante à plataforma petista, a propaganda de Lula também defendeu a necessidade da retomada do crescimento econômico e geração de empregos como prioridades essenciais. Mas de maneira diversa do programa de governo do PT, que defendia uma "ruptura" efetiva com a política econômica vigente, Lula reiterou sua postura assumida na "Carta ao Povo Brasileiro" (divulgada em 22 de junho de 2002) de promover uma mudança "responsável" e "segura" no país: "vamos honrar todos os compromissos assumidos pelo governo, vamos manter a inflação sob controle e as metas de superávit necessárias, mas temos que mudar essa política perversa do governo que gera desemprego".

Lula defendeu em sua propaganda um projeto detalhado para a criação de empregos, que em resumo baseava-se nas seguintes propostas: aumento das exportações; redução da taxa de juros; reforma agrária; reforma tributária "justa" para desonerar a produção; incentivo à construção de casas populares, ao turismo e agroindústria; abertura de crédito às pessoas que trabalham por conta própria através do Banco do Povo; e criação da carteira profissional do $1^{\circ}$. emprego aos jovens entre 16 e 21 anos sem experiência profissional. 
$\mathrm{Na}$ área da saúde, a promessa tinha como alvo a melhora da qualidade e a rapidez do atendimento em hospitais públicos, a implantação da "Farmácia Popular" (projeto que previa a venda de remédios mais baratos), a ampliação da distribuição de medicamentos em hospitais públicos e postos de saúde e também a extensão dos programas de medicina preventiva.

A violência, segundo Lula, tinha suas raízes no aumento da fome, falta de oportunidades de trabalho, drogas em geral, acrescidas da corrupção policial e descaso das grandes autoridades. Para combatê-la propunha a demissão dos maus policiais de todas as patentes, equipar e remunerar melhor a polícia e a criação da Agência Nacional da Segurança Pública (ANSP), vinculada diretamente à presidência da República e com a função de coordenar e integrar as ações da Polícia Federal, Civil e Militar, fiscalizando e dando apoio aos Estados através de forças-tarefa, equipamentos e informação. Além da proposta de mudança na estrutura policial, havia a preocupação de criar projetos sociais de lazer, esporte e cultura, que somados ao programa " 1 ". emprego", evitariam que os jovens se tornassem presas fáceis dos traficantes.

O projeto de Lula para educação tinha, como prioridade, a melhora do ensino público e, para isso, a proposta era aumentar em $\mathrm{R} \$ 33$ milhões a verba destinada para essa área, valorizar e capacitar melhor os professores, ampliar as quotas de vagas para negros nas universidades públicas e estender, para todo o Brasil, o projeto "Vai e Volta" da prefeitura paulistana petista, que oferecia transporte, uniforme e material escolar gratuito aos alunos.

A preocupação com o combate à fome foi bastante destacada na propaganda de tevê. Segundo Lula, o problema da fome, que não se restringia ao Nordeste, sendo notada também nas periferias das grandes cidades, não era causado pela falta de produção de alimentos, mas pela falta de renda das famílias para adquirir os alimentos na quantidade necessária e com a qualidade adequada. Nesse sentido, seu projeto contra a fome apresentava as seguintes medidas: incentivo à agricultura familiar; reforma agrária "justa", pacífica e "bem planejada"; ampliação do micro-crédito, sem avalista, através do Banco do Povo; programa de renda mínima e bolsa-escola; ampla política de 
desenvolvimento e geração de empregos nos pequenos municípios do interior do país.

À parte da apresentação das propostas de políticas para um futuro governo petista, a propaganda eleitoral de tevê buscou reforçar a reconstrução da imagem de Lula, já iniciada nos programas partidários do PT, veiculados entre abril e maio de 2002. As qualidades de Lula expostas em relevo diante das telas foram as seguintes: a de um "político negociador", evocado pelo passado sindicalista; um "grande estadista", que sabia ouvir os diferentes setores da sociedade e encontrar soluções em conjunto para os problemas do país; a de um político que tinha uma família e era atencioso e carinhoso com sua esposa e filhos; a ênfase num candidato calmo, tranqüilo e maduro, que havia conhecido lideranças de esquerda de outros países - como Jospin da França, tentando, assim, desvencilhar-se da imagem de radical associada ao candidato petista em campanhas presidenciais passadas. Além disso, tendo como objetivo neutralizar as resistências daqueles que 0 viam como despreparado em função de sua baixa escolaridade, a propaganda mostrou o petista como parte integrante de uma equipe de pessoas com alto nível técnico $^{72}$, as quais não somente haviam ajudado a formular seu programa como o acompanhariam em seu eventual governo.

A propaganda foi um espaço bastante explorado para a manifestação realização de apelos patrióticos e de esperança no futuro. Uns expressos através de crianças, mulheres grávidas, jovens, jingles ${ }^{73}$ e da fala do próprio Lula, incitavam os brasileiros a terem esperança de "um Brasil melhor e mais decente"; outros, exaltavam a pátria, por meio do hino nacional, cantado pelo grupo Ilê Aiyê, e de manifestações de orgulho do país e de ser brasileiro.

\footnotetext{
${ }^{72}$ A respeito dessa questão, Fausto Neto diz o seguinte sobre Lula na propaganda de televisão: "Ao seu lado, são igualmente mostradas imagens de respeitáveis técnicos, imagens que compõe a abertura do seu programa, cujo efeito de sentido é testemunhalizar que Lula não está numa aventura. Pelo contrário, figuras expressivas que constituem o mundo empresarial, acadêmico, político, financeiro, estão ali com ele, tecendo, no tempo da TV, o seu programa de governo". Ver FAUSTO, NETO, 2003, P. 74".

${ }^{73}$ Nesse sentido, um refrão bastante usado na propaganda de Lula foi aquele em que dizia: "Agora é Lula. Falta pouco quase nada. Nossa pátria tão amada. Já não pode mais esperar".
} 
Tratou-se, por outro lado, de evitar a estratégia de ataques aos adversários, mesmo porque, estando liderando a disputa, tal estratégia somente daria combustível a seus adversários. Assim, buscando reforçar a marca registrada de "paz e amor" atribuída a Lula durante a campanha, a propaganda petista invocou não só figuras como John Lennon, Nelson Mandela, Madre Teresa de Calcutá e Celso Daniel, como fez também uma homenagem às vítimas dos atentados terroristas de 11 de setembro e às vítimas de guerra e violência no mundo de alguma forma.

Embora a publicidade de Lula na televisão tivesse como principal linha tática não atacar os rivais, a propaganda não se constituiu apenas e tãosomente de "paz e amor", tendo havido algumas demonstrações de reação contra o candidato Serra, tanto no primeiro como no segundo turno. Em 19 de setembro, pela primeira vez o horário eleitoral petista atacou Serra, alegando que o adversário governista estava instituindo o "terror" contra Lula e o PT. Revidando à crítica tucana de que o candidato petista era despreparado porque não tinha diploma, a apresentadora do programa dizia que "a questão não é quem tem diploma", mesmo porque Collor, vitorioso na eleição de 1989 e afastado do cargo por corrupção, "era formado e tinha diploma". A mesma apresentadora respondeu ao ataque tucano que colocava em dúvida a viabilidade do programa de Lula de criar 10 milhões de empregos. Em seguida era exibido um gráfico do aumento do desemprego no período em que o candidato do governo foi o ministro do Planejamento de Fernando Henrique: "Serra já teve oportunidade de criar empregos, mas não foi capaz de criar um só emprego". Outro apresentador descreveu Lula como "alguém hábil para agregar e somar", referência indireta à atribuição de "desagregador" que adversários costumavam imputar ao candidato tucano.

Após uma pesquisa realizada pela equipe da campanha de Lula, a qual mostrou que a maior parte dos eleitores entrevistados rejeitava a resposta aos ataques de Serra no horário eleitoral de televisão, a campanha petista seguiu sem fazer propaganda negativa até o final do primeiro turno. No segundo turno, a publicidade de Lula manteve a estratégia de não reagir às investidas de seu rival, embora tenha colocado a proposta tucana de 8 milhões de empregos 
como foco de questionamento, sob à argumentação de que a política econômica do governo, da qual Serra pertenceu, eliminou os postos de trabalho, além de ter acusado o adversário tucano de agir de maneira irresponsável por amedrontar o povo brasileiro através de uma propaganda que apresentava o PT como "partido da bagunça e das greves".

Por fim, com o objetivo de manter o eleitor informado sobre as atividades de campanha, a propaganda relatava os lugares onde Lula tinha estado e mostrava imagens dos comícios e das passeatas realizados, lançando mão principalmente dos chamados "pseudo-eventos"74. Também resgatou cenas da campanha presidencial de 1989, enfatizando, através da voz de um locutor em off , que "hoje, o Lula e o PT se encontravam em um outro patamar".

A tônica predominante do conteúdo da propaganda eleitoral da candidatura de Lula, como podemos notar na TAB. 3.3, correspondeu à categoria de assuntos substantivos (71,56\%), ou seja, a maior parte do tempo da propaganda dedicou-se às propostas, problemas e questões. Assim, apenas 23,45\% foram dedicadas a categoria assuntos restantes, ou seja, os referentes ao desenrolar da campanha (agenda de campanha dos candidatos, estratégias e apoios) pesquisas, bem como os que ressaltam as qualidades pessoais do candidato, apelos de esperança, mudança e de alusão à pátria. Deste modo, os dados evidenciam que a agenda de Lula na propaganda preocupou-se sobremaneira com a apresentação das propostas de políticas públicas.

TABELA 3.3 - Assuntos da propaganda de Lula na televisão $\left(1^{\circ}\right.$. e $2^{\circ}$. turnos da eleição presidencial de $\left.2002^{75}\right)$ - em porcentagem

\footnotetext{
${ }^{74}$ Acontecimentos planejados direcionados à cobertura da mídia em geral. Cf. Boorstin, 1961.

${ }^{75}$ De 20 de agosto a 3 de outubro de 2002, no primeiro turno; e de 14 a 25 de outubro de 2002 , no segundo turno.
} 


\begin{tabular}{lcc}
\hline Categoria de assuntos & $(\%)$ & ordem \\
\hline Substantivos & 34,16 & 1 \\
economia & 3,54 & 8 \\
social em geral & 13,9 & 2 \\
educação & 2,95 & 9 \\
fome & 9,75 & 3 \\
saúde & 1,87 & 12 \\
infra-estrutura & 0,69 & 14 \\
cultura/lazer/etnia & 4,5 & 6 \\
segurança & 0,05 & 17 \\
meio-ambiente & 0,14 & 16 \\
cidades & 0,01 & 18 \\
Forças Armadas & $\mathbf{7 1 , 5 6}$ & \\
Subtotal & & \\
& & \\
Restantes & 8,26 & 4 \\
campanha & 0,62 & 15 \\
pesquisas & 2,2 & 11 \\
qualidades pessoais & 4,77 & 5 \\
esperança & 1,22 & 13 \\
ataques & 2,49 & 10 \\
mudança & 3,89 & 7 \\
pátria & $\mathbf{2 3 , 4 5}$ & \\
Subtotal & & \\
outros & $\mathbf{4 , 9 9}$ & \\
\hline Total & 100 & \\
\hline (n=21.694*) & & \\
\hline & &
\end{tabular}

* $N$ é o total de tempo de todas as categorias.

Dentre os assuntos substantivos, a propaganda de Lula concentrou-se mais na discussão em torno da categoria econômica (34,16\%), educação $(13,9 \%)$ e saúde $(9,75 \%)$. Quanto à questão do destaque da economia, os temas sobre emprego, exportação e crescimento econômico foram os que mais apareceram nesta categoria.

Em relação aos assuntos restantes, a propaganda de Lula deu maior ênfase aos assuntos sobre campanha (8,26\%), apelos de esperança $(4,77 \%)$, patrióticos $(3,89 \%)$, e de mudança $(2,49 \%)$. 


\section{A propaganda de Serra}

Em termos de formato a propaganda tucana não se diferenciou muito da de Lula. Assim como esta, deu maior saliência às propostas do programa de governo e tratou de construir uma imagem positiva de Serra salientando suas qualidades pessoais. A diferença mais importante é quanto ao uso mais enfático da estratégia de ataques aos adversários pela candidatura tucana.

Quanto ao aspecto programático, a temática central referiu-se à questão do emprego. Todas as propostas a respeito desse assunto, presentes no programa "Trabalho e progresso para todos", deram origem ao "Projeto $2^{\mathrm{a}}$. Feira". Esse conjunto de proposições para a criação de postos de trabalho foi explicado minuciosamente pelo candidato, uma vez que, sendo seu programa de tevê o de maior duração, tinha tempo suficiente para essa exposição. De modo geral, o emprego foi tomado como a principal mudança que seu governo iria realizar e nesse sentido tornou-se o slogan da campanha tucana: "a mudança tem nome: é emprego. A mudança tem cor: o azul da carteira de trabalho. A mudança tem número: 8 milhões de empregos".

$\mathrm{Na}$ saúde, à parte da apresentação das propostas neste setor, a propaganda sublinhou as realizações de José Serra como ministro da Saúde do governo de Fernando Henrique. Para os idosos, recordou que o candidato havia acabado com as filas de espera para as cirurgias de catarata, reduzido os impostos dos remédios de uso continuado e feito exames nacionais de diabetes e de pressão alta. Dentre as realizações para a mulher, foram recapitulados feitos como o parto com anestesia, bolsa-alimentação, a execução de 33 milhões de exames de câncer de colo do útero e a criação dos "agentes de saúde em casa".

Além de expor o conjunto de medidas para a área da segurança no horário eleitoral, que segundo Serra iria fazer com que a polícia agisse de maneira mais eficiente contra o crime, também mostrou depoimentos de parentes de vítimas de violência, colhidos pela autora de novela Glória Perez. Serra prometeu realizar mudanças no Código Penal, de modo que os criminosos passassem a receber penas mais severas. 
Serra foi lembrado como um político dono de uma longa trajetória administrativa: Secretário de Economia e Planejamento do estado de São Paulo na gestão de Franco Montoro, duas vezes deputado federal e Ministro do Planejamento e da Saúde no governo FHC. O reconhecimento mundial de algumas de suas realizações, como a campanha contra a aids e anti-tabagista, bem como a introdução dos genéricos no Brasil, foram tomados como aval de sua competência administrativa, a qual o qualificava como candidato mais preparado para realizar as mudanças, como dizia um dos jingles da propaganda: "Se José Serra já fez tanto na saúde, é o mais preparado para ser nosso presidente". No plano das qualidades pessoais, Serra foi destacado como um "político de coragem", por ter desafiado a ditadura em defesa dos ideais democráticos; como honesto, que cumpre o que promete, "dito e feito" afirmava um spot; e ainda como "realizador", que colocava em prática seus projetos: "Serra sabe o que fazer, Serra tira do papel".

A campanha tucana na tevê fez uma ampla utilização da propaganda negativa contra os adversários de Serra. Ciro foi o primeiro alvo. Dentre os vários ataques, os principais foram: a associação do candidato da Frente Trabalhista ao ex-presidente Fernando Collor de Mello num trecho do horário eleitoral, em que uma foto de Collor aparecia e, logo em seguida, um locutor descrevia um "ex-governador" agressivo com os adversários e a imprensa e, no final, dizia que a descrição servia tanto para Collor quanto para Ciro; a veiculação de uma séria de afirmações desabonadoras divulgadas pela mídia: como aquela na qual chamou um "eleitor de burro", em que comparou os médicos a sal, "branco, barato e que era encontrado em qualquer esquina", ou quando disse que "os petistas são uns mijões nas calças" e que "os separatistas do sul têm desvio homossexual"; a tentativa de transmitir a imagem de um candidato que brigava com todos e a idéia de que Ciro era "mentiroso", mal administrador - através da ênfase em aspectos negativos de seu governo no Ceará e de sua administração à frente do Ministério da Fazenda; o questionamento das alianças de Ciro com Antônio Carlos Magalhães e Leonel Brizola, uma vez que, em épocas passadas, havia dito "ACM é mais sujo do que pau de galinheiro" e que "Brizola é a fina flor do atraso". Assim sendo, a propaganda de Serra na televisão 
objetivou desconstruir a imagem de Ciro, mostrando-o como um político despreparado.

A partir de meados de setembro, depois de ter voltado a ocupar a segunda posição nas pesquisas de intenção de voto, José Serra deixou de lado Ciro Gomes e direcionou a propaganda negativa a Garotinho e Lula. Contra o candidato do PSB, os ataques foram esporádicos e ocorreram exclusivamente nos spots. A estratégia consistiu na alegação de que Garotinho mentia ao divulgar, no horário eleitoral de tevê, que havia construído 500 mil casas populares e que diminuíra a violência no estado do Rio de Janeiro. Neste último caso, a propaganda tucana mencionava que tinha sido na gestão de Garotinho que ocorrera uma chacina, comandada por um bandido dentro da cadeia de Bangu-I, através do uso de celular.

Contra Lula, uma gama de ataques foi disseminada durante o primeiro e segundo turnos. No primeiro, a capacidade administrativa do candidato petista foi colocada em questão, através da contestação de que Lula não possuía formação superior e nunca tivera uma função além de sindicalista e de uma breve passagem pelo Congresso como deputado. A tentativa era desqualificálo, mostrando-o como despreparado para assumir o cargo de Presidente da República e incapaz de gerar empregos para a população. Num dos programas eleitorais, a propaganda tucana colocava lado a lado a biografia política de Lula e de Serra e, em seguida, levantava a questão: "Quem vai gerar mais empregos, Serra ou Lula?"

Na tentativa de associar o $\mathrm{PT}$ ao radicalismo, a propaganda de Serra usou um discurso de José Dirceu (deputado federal e coordenador da campanha de Lula), em que este afirmava que "eles devem apanhar nas ruas e nas urnas", para relacioná-lo a imagens de uma agressão sofrida por Mário Covas numa manifestação de professores em São Paulo. Dias após dessa veiculação no programa de televisão, a Justiça Eleitoral vetou a reapresentação daquelas imagens. Mas a propaganda serrista não parou com os ataques e insistiu nessa questão, trazendo o depoimento da filha de Covas, que reafirmou a suposta relação entre José Dirceu e a agressão a seu pai. 
Após esses ataques ao rival petista e a estagnação nas pesquisas eleitorais, José Serra se desentendeu com seu marqueteiro, Nizan Guanaes, responsável pela propaganda até aquele momento. $\mathrm{Na}$ avaliação do candidato e também de Fernando Henrique Cardoso, foi um erro deixar o debate programático com Lula e partir para ataques diretos. Provavelmente em função disso a propaganda de Serra deixou de atacar os adversários na última semana de propaganda do primeiro turno.

No segundo turno, Serra adotou outras táticas de ataques. Chamou insistentemente o candidato petista para o debate, através da pergunta "E agora Lula, Vai ou não vai? Serra vai", e afirmou que Lula fugia dos debates porque tinha medo de discutir suas propostas. Com a finalidade de mostrar ao eleitor as incoerências dos ex-presidenciáveis, Ciro e Garotinho, que, no segundo turno, estavam apoiando a candidatura petista, lembrou que o primeiro fez a seguinte declaração: "quem quer tocar fogo no país e fazer uma aposta onde não sabe no que vai dá, vota no Lula", e que o segundo tinha criticado Lula e o PT pela não implantação da Ford no estado do Rio Grande do Sul, que, na época, era administrada pelo partido. A propaganda tucana associou Lula e o PT ao Movimento dos Trabalhadores Rurais Sem Terra (MST) e à Central Única dos Trabalhadores (CUT): "Uma coisa que a gente se pergunta: é que agora Lula só mostra empresários de seu lado. Mas onde está a CUT? Onde está o MST? Que papel teria no governo Lula?"; ao presidente da Venezuela, Hugo Chávez e às Forças Armada Revolucionárias da Colômbia (FARC). Bateu na tecla do risco do "Brasil virar uma Argentina", no caso de vitória de Lula, enfatizando a crise econômica argentina como um paradigma que não queríamos. Trouxe a atriz Regina Duarte para a propaganda, declarando estar com medo de uma possível vitória de Lula, por colocar por terra todas as realizações do governo de Fernando Henrique. Ressaltava que tais realizações que Serra ajudara a conquistar, como a queda da inflação, o Plano Real, os genéricos, o programa saúde da família e de combate à aids, poderiam ir, do dia para a noite, "tudo para a lata do lixo".

No final do segundo turno, o confronto continuou, mas a tentativa da propaganda de Serra foi minar a tática de Lula de tomar os governos petistas 
no Brasil como exemplos de administrações bem sucedidas. Um apresentador dizia no horário de tevê: "O PT é mais competente na hora de fazer críticas do que ser governo. As administrações petistas são exemplos de incompetência administrativa". Em seguida, o locutor criticava o governo do PT do Rio Grande do Sul, alegando ter sido este o responsável pela Ford deixar de se instalar no estado além de ter levado ao aumento da violência no estado gaúcho.

Além da estratégia de ataques aos adversários, a propaganda utilizou-se dos "pseudo-eventos" da campanha de Serra, com a divulgação das viagens, comícios, passeatas, eventos e apoios de políticos e lideranças sociais.

Em termos quantitativos, na propaganda do candidato José Serra, da mesma forma que na de Lula, predominou a categoria de assuntos substantivos $(59,34 \%)$, tendo havido, pois, na maior parte do tempo de tevê, a exibição de propostas de políticas públicas e a discussão de temas concretos. No entanto, há distinções de proporção, uma vez que a publicidade de Serra, em relação à de Lula, empregou $10,51 \%$ pontos percentuais a mais de assuntos restantes (ver TAB. 3.4). 
TABELA 3.4 - Assuntos da propaganda de Serra na televisão

$\left(1^{\circ}\right.$. e $2^{\circ}$. turnos da eleição presidencial de $\left.2002^{76}\right)-$ em porcentagem

\begin{tabular}{lcc}
\hline Categorias de assuntos & $(\%)$ & ordem \\
\hline Substantivos & 32,3 & 1 \\
economia & 5,53 & 7 \\
social em geral & 4,31 & 8,5 \\
educação & 0,09 & 17 \\
fome & 7,66 & 4 \\
saúde & 1,45 & 11 \\
infra-estrutura & 0,04 & 18 \\
cultura/lazer/etnia & 5,69 & 6 \\
segurança & 0,66 & 13 \\
regiões brasileiras & 0,14 & 15 \\
meio-ambiente & 0,44 & 14 \\
assuntos estrangeiros & 1,03 & 12 \\
cidades & 59,34 & \\
Subtotal & & \\
Restantes & & \\
campanha & 6,43 & 5 \\
pesquisas & 1,98 & 10 \\
qualidades pessoais & 12,32 & 2 \\
ataques & 8,81 & 3 \\
mudança & 4,31 & 8,5 \\
pátria & 0,11 & 16 \\
Subtotal & 33,96 & \\
outros & & \\
\hline Total & $\mathbf{6 , 7}$ & \\
\hline
\end{tabular}

${ }^{*} N$ é o total de tempo de todas as categorias.

Quanto aos temas referentes aos assuntos substantivos, vê-se que, de maneira similar ao caso de Lula, a propaganda de Serra teve a questão da economia como foco principal (32,3\%), sendo o emprego a preocupação mais

\footnotetext{
${ }^{76}$ De 20 de agosto a 3 de outubro de 2002, no primeiro turno; e de 14 a 25 de outubro de 2002 , no segundo turno.
} 
veiculada, devido à centralidade do "Projeto $2^{\mathrm{a}}$. feira". O segundo assunto substantivo de maior destaque da propagada de tevê de Serra foi a saúde (7,66\%), o que confirma a ênfase dada às realizações do candidato quando ocupou o Ministério da Saúde.

No que se refere aos assuntos restantes veiculados na propaganda, as qualidades pessoais de Serra foram as que mais se destacaram $(12,32 \%)$ e, logo em seguida, os ataques $(8,81 \%)$ e apelos de mudança $(4,31 \%)$.

Quanto à estratégia da utilização da propaganda negativa, levada a cabo pela propaganda tucana, estudos internacionais mostram que, quanto mais acirrada a campanha, maior a agressividade na propaganda de tevê através da política negativa (Jamieson, 1993; Jamieson e Waldman, 2003). Como vimos, no primeiro turno ocorreu uma disputa muito apertada entre Ciro e Serra pelo segundo lugar, por isso a tática da equipe de marketing tucana foi a de realizar ataques contra o candidato Ciro Gomes, que havia ultrapassado Serra em julho e na primeira quinzena de agosto. À medida que o candidato da Frente Trabalhista ficou para trás nas pesquisas, Lula passou a ser o principal alvo de Serra na tevê. No segundo turno, os ataques a Lula permaneceram como uma importante arma do candidato governista.

\subsection{Cobertura de Lula e de Serra nos telejornais}

As coberturas das quatro principais candidaturas à presidência da República, Luiz Inácio Lula da Silva, José Serra, Ciro Gomes e Anthony Garotinho, efetuadas pelo Jornal Nacional e Jornal da Record, foram, de maneira geral, bastante parecidas quanto à questão dos formatos de apresentação das notícias.

Os dois noticiários de tevê veicularam suas matérias diárias sobre o processo eleitoral, através de um bloco, dividido em quatro partes, cada qual referente a uma candidatura específica e constituída pela exibição das 
atividades de campanha e declarações dos candidatos $^{77}$. De maneira semelhante também, ambos exibiram entrevistas ao vivo com os principais postulantes ao cargo de Presidente da República, bem como divulgaram os resultados das pesquisas de intenção de voto, realizadas pelos diversos institutos de opinião pública do país. Além desse aspecto dos formatos, outro ponto em comum foi o equilíbrio de espaço dados aos principais candidatos ${ }^{78}$.

\section{A cobertura de Lula}

Os telejornais observados relataram, diariamente, no primeiro e segundo turnos, a agenda das atividades e compromissos de campanha de Luiz Inácio Lula da Silva, ou seja, as palestras, passeatas, comícios, comemorações e encontros com lideranças sociais e políticas. Também informaram a agenda do final da noite e do dia seguinte do candidato petista. Segue-se um exemplo deste tipo de cobertura no Jornal Nacional:

Repórter: O dia de Lula começou com a gravação de programas eleitorais. $\mathrm{Na}$ chegada à produtora, o candidato do PT deu uma explicação aos fotógrafos e cinegrafistas. Lula seguiu para o estúdio, onde ficou por três horas. Neste período, mais um partido de esquerda, o PSTU, anunciou apoio a Lula. Neste hotel de SP, o candidato do PT almoçou com os coordenadores da campanha e tratou da estratégia para o segundo turno (...) No fim da tarde, Lula viajou para Natal, onde realiza um comício ainda esta noite. Amanhã o candidato do PT faz campanha em outras três capitais do nordeste: Aracaju, Recife e João Pessoa.

A divulgação de trechos de discursos de Lula em eventos, palestras, etc. e as respostas dele às perguntas dos jornalistas, além das entrevistas que

\footnotetext{
77 Discurso sem interrupção de uma fonte durante a apresentação de notícias. Cf. HALLIN, 1992.

${ }^{78}$ Ver os trabalhos de Silva (2003); Miguel (2003) e de Porto (2004).
} 
participou nos estúdios dos telejornais, foram a principal forma através da qual as questões mais programáticas da campanha vieram à baila nos noticiários. Nele, o foco recaiu na reafirmação de Lula acerca do compromisso de honrar os contratos e acordos do governo: "Sabemos que a atual crise nos mercados financeiros pode ser superada sem a quebra de contrato e sem surpresas"; e na questão da mudança segura: "Ninguém tem o direito de fazer experimentações, nem de brincar com o povo brasileiro".

O telejornal ainda enfatizou falas de Lula que continham criticas ao governo Fernando Henrique Cardoso e que reforçavam as promessas do candidato petista de geração de empregos, de crescimento econômico, e de investimentos na educação, saúde e segurança. A respeito deste último tópico, as frases do candidato petista destacavam a necessidade de combater o crime através do investimento em lazer, cultura e demissão dos maus policiais de todas as patentes.

Quanto ao aspecto da veiculação de questões mais programáticas de Lula, o Jornal da Record também salientou os mesmos pontos que o Jornal Nacional, diferenciando-se apenas por ter dado mais destaque às críticas de Lula ao governo vigente. No tocante à geração de empregos, o telejornal da Record divulgou a discussão, feita por Lula no horário eleitoral, de que se a construção de uma plataforma de petróleo da Petrobrás fosse realizada no Brasil, e não em Cingapura, geraria vários empregos para o país.

O Jornal Nacional enfatizou, especialmente através das declarações do candidato do PT, as qualidades pessoais, que revelavam um Lula calmo: "Eu não vou fazer como das outras vezes em que eu ficava nervoso, ficava gritando na televisão..."; um político que tinha uma família e que estava contente: "Eu quero dizer a vocês que eu nunca me senti tão bem preparado na minha vida. Estou de bem com a vida. Estou de bem com a vida, com a minha família...de bem com a minha consciência"; e, acima de tudo, um candidato negociador: "vou ser o presidente do diálogo, da conversa, ouvindo governadores, prefeitos, empresários e produtores rurais". 
Outra questão, presente em ambos os telejornais, referiu-se aos assuntos estrangeiros. Dentre eles estavam a discussão sobre o tratado de não-proliferação de armas nucleares; a suposta relação entre o PT e as Forças Revolucionárias da Colômbia (FARC); a construção da base aérea de Alcântara, no Maranhão; a relação de Lula com Cuba e Venezuela; e o questionamento da afirmação do candidato petista, de que o "Brasil não viraria uma Argentina, porque não era nenhuma 'republiqueta' ".

Particularmente no Jornal da Record, alguns ataques do candidato petista foram exibidos. A reação de Lula ocorreu na medida em que os jornalistas o questionavam sobre o que achava dos ataques de seu rival, José Serra, contra ele. Embora, em algumas vezes afirmasse que não iria responder, em muitas outras, o candidato petista aproveitou as perguntas para revidar, chamando Serra de "chorão" - porque ficava pedindo direito de resposta junto à Justiça Eleitoral, comparando-o a um "afogado que estendia a mão pedindo ajuda" ou quando retrucou que Serra era o candidato do governo e, juntamente com este, era também responsável pelo desemprego no país: "Ele deveria olhar para o que eles fizeram em oito anos, só isso, ou seja, eu vou recuperar os postos de trabalho que eles fecharam em 8 anos".

De maneira similar, os dois telejornais deram bastante ênfase à questão das estratégias de campanha. Normalmente, os jornalistas indagavam a Luiz Inácio Lula da Silva acerca de qual estratégia ele iria adotar perante os ataques de José Serra, isto é, se iria manter a tática "paz e amor" ou revidaria na propaganda tucana na tevê. No Jornal da Record, o âncora e apresentador, Boris Casoy, ainda realizou vários comentários analíticos sobre as estratégias do candidato petista no horário eleitoral.

Quanto às pesquisas de intenção de voto, as enquetes, realizadas pelos institutos de opinião pública, foram difundidas quase que semanalmente pelos dois telejornais observados, acentuando-se no final do primeiro e segundo turnos, devido ao aumento das pesquisas efetuadas. No Jornal da Record especialmente, além da apresentação dos testes de opinião pública num bloco separado da cobertura da agenda dos candidatos, Boris Casoy constantemente 
comentava as pesquisas. Abaixo, segue-se um comentário dessa natureza feita pelo jornalista:

Lula está, segundo o Datafolha e também segundo o Vox-Populi, muito perto de uma vitória ainda no primeiro turno. Não está garantida, é possível, não está certa, mas entramos num momento cinza, onde tudo pode acontecer. Ele pode conseguir ganhar em primeiro turno ou pode recuar. Estamos na última semana, a eleição é domingo que vem...as pesquisas indicam a possibilidade dele ganhar no primeiro turno. No segundo turno Lula já está, não se sabe quem será o companheiro dele.

Os dados da TAB. 3.5 confirmam o que dissemos anteriormente. Os assuntos sobre o candidato petista que mais sobressaíram na cobertura dos telejornais foram aqueles classificados como restantes (74,04\%), principalmente a categoria campanha $(44,77 \%)$ - que incluiu informações da agenda dos candidatos, condução de campanha e estratégias - e a respeito das pesquisas eleitorais (24,02\%). Conseqüentemente, o enfoque nos assuntos substantivos foi baixo, isto é, menos de 30\%, sendo a economia $(17,02 \%)$ e a segurança $(1,69 \%)$ os assuntos que ganharam mais importância na cobertura de Lula nos dois telejornais vistos conjuntamente.

TABELA 3.5 - Assuntos da cobertura eleitoral de Lula nos telejornais, Jornal Nacional e Jornal da Record $\left(1^{\circ}\right.$. e $2^{\circ}$. turnos da eleição presidencial de $\left.2002^{79}\right)$ - em porcentagem

\footnotetext{
${ }^{79}$ De 20 de agosto a 5 de outubro de 2002, no primeiro turno; e de 14 a 26 de outubro de 2002 , no segundo turno.
} 


\begin{tabular}{|c|c|c|c|}
\hline \multicolumn{2}{|c|}{ Categoria de assuntos } & $(\%)$ & ordem \\
\hline \multicolumn{4}{|c|}{ Substantivos } \\
\hline & economia & 17,02 & 3 \\
\hline & social em geral & 0,5 & 8 \\
\hline & educação & 0,41 & 10 \\
\hline & fome & 0,13 & 13 \\
\hline & saúde & 0,44 & 9 \\
\hline & infra-estrutura & 0,26 & 11 \\
\hline & cultura/lazer/etnia & 0,19 & 12 \\
\hline & segurança & 1,69 & 5 \\
\hline & regiões brasileiras & 0,09 & 17 \\
\hline & meio-ambiente & 0,12 & 14,5 \\
\hline & assuntos estrangeiros & 1,51 & 6 \\
\hline & cidades & 0,03 & 20 \\
\hline & Forças Armadas & 0,12 & 14,5 \\
\hline Subtc & & 22,51 & \\
\hline \multicolumn{4}{|c|}{ Restantes } \\
\hline & campanha & 44,77 & 1 \\
\hline & pesquisas & 24,02 & 2 \\
\hline & qualidades pessoais & 1,47 & 7 \\
\hline & esperança & 0,09 & 17 \\
\hline & ataques & 3,53 & 4 \\
\hline & mudança & 0,09 & 17 \\
\hline & pátria & 0,07 & 19 \\
\hline Subtc & & 74,04 & \\
\hline outrc & & 3,45 & \\
\hline Total & $\left(n=18.948^{\star}\right)$ & 100 & \\
\hline
\end{tabular}

* $N$ é o total de tempo de todas as categorias.

\section{A cobertura de José Serra}

A cobertura do candidato do PSDB no Jornal Nacional e Jornal da Record caracterizou-se pela veiculação de uma parte mais substantiva, referente ao debate de questões sobre programas de governo, mediante declarações de Serra e de perguntas dos jornalistas, e, de outra, centrada na divulgação das atividades de campanha e retratação das pesquisas eleitorais.

Na parte programática, ambos telejornais destacaram mais a questão da geração de empregos, através da transmissão de frases de Serra referentes ao "Projeto $2^{a}$. feira", que previa a geração de 8 milhões de empregos no país por meio da retomada do crescimento econômico e do investimento em setores estratégicos, como agricultura, construção civil, turismo, saúde e educação: "Eu 
sou o candidato a presidente por um motivo: para gerar, nos próximos 4 anos, 8 milhões de empregos por todo o nosso território, na agricultura, nas cidades, na indústria e no comércio" 80 .

As propostas de José Serra para a área da segurança também foram alvo de exibição nos noticiários. Freqüentemente 0 candidato tucano discursava e respondia perguntas sobre este tema, ressaltando suas propostas, como a reforma da legislação penal, construção de presídios federais e a criação do Ministério da Segurança Pública, para, segundo ele, fazer com que o governo federal tivesse uma participação mais ativa na questão da segurança.

As pesquisas foram tratadas de maneira semelhante tal qual ocorrera na cobertura de Lula. Esse assunto ainda surgiu constantemente nos noticiários através das perguntas dos jornalistas e respostas do candidato do PSDB. Exclusivamente no telejornal da Rede Record de televisão, os comentários de Boris sobre as pesquisas especulavam quais as chances de Serra ir para o segundo turno e de se aproximar de Lula nos testes de opinião.

As frases divulgadas de Serra mostravam-no como um político preparado, com uma extensa experiência na vida pública e o mais capaz de gerar os 8 milhões de empregos prometidos.

No telejornal da Rede Globo, embora de maneira bem menos freqüente do que no Jornal da Record, foram divulgados os ataques de Serra contra Lula, principalmente aqueles em que o candidato tucano chamava o petista para o aprofundamento do debate sobre os problemas do país: "Nós queremos debater como resolver os problemas do país. É muito fácil apontar problemas, o Brasil tá cheio de problemas, mas é fundamental discutir quem é capaz de efetivamente resolvê-los". A crítica de Serra de que o Brasil corria o risco, caso Lula viesse vencer a eleição, de passar pelos mesmos problemas que alguns países latinoamericanos estavam passando naquele momento particular, também veio à tona na cobertura: "Venezuela e Argentina atravessaram esse processo de mudança

${ }^{80}$ Jornal Nacional, 21 de agosto de 2002. 
para pior, pois são exemplos de sonhos perdidos porque foram prometidos em campanhas eleitorais e que não foram cumpridos".

O Jornal da Record exibiu os ataques de Serra contra seus três opositores: Ciro, Garotinho e Lula. Em relação ao primeiro, o candidato tucano responsabilizou Ciro, quando era governador do Ceará, por um grave surto de cólera neste estado. Ademais, as afirmações de Serra e de lideranças do PSDB de que Ciro era despreparado, tropeçava nas palavras e era uma pessoa "impulsiva" e "mentirosa" foram freqüentes no telejornal. Quanto aos ataques a Garotinho, o noticiário publicou a acusação de Serra de que Garotinho era responsável pela permissão do uso de celular por bandidos na cadeia de Bangu-I, e que o candidato do PSB tinha enfrentado a segurança no Rio de Janeiro "com maquiagem e com marketing" e deixado uma "bombarelógio" no estado".

Por fim, quanto aos ataques desferidos contra Lula, os seguintes foram divulgados: as críticas ao programa do candidato do PT sobre a criação de 10 milhões de empregos no Brasil; trechos nos quais Serra atacava a administração petista do Rio Grande do Sul, dizendo que "o PT havia isolado o progresso daquela região e sido cúmplice de invasões de terra, atraso de salários e não cumprimento das exigências constitucionais em relação à educação e saúde"; acusações de que o PT tinha várias caras: "Você tem o PT do mercado, que quer tranqüilizar o mercado. Tem o PT que quer tranqüilizar o MST. Tem o PT que quer tranqüilizar o sindicato, etc., o discurso vai variando"; frases de Serra em que este afirmava sobre a possibilidade do PT levar o país a cenários semelhantes aos da Venezuela, de Hugo Chávez e da Argentina, de Fernando Della Rua: "A Venezuela e a Argentina elegeram presidentes que prometeram resolver tudo, prometiam fazer mudança. Olha, eles trouxeram mudança, mas pra muito pior"; e também insinuações do candidato tucano de que uma vitória de Lula significaria um "estelionato eleitoral":

Por isso, eu repito, uma vitória da oposição hoje, representaria de duas uma, ou um estelionato eleitoral, como nós nunca vimos desde Collor, no sentido de não fazer nada daquilo que está prometendo fazer, ou então a 
superinflação e a desorganização da nossa economia, se tentar cumprir essas promessas mágicas.

Os dados da TAB. 3.6 elucidam que a cobertura de Serra nos telejornais enfatizou de maneira predominante os assuntos referentes à campanha $(44,32 \%)$ e às pesquisas de intenção de voto (23,01\%). Os assuntos substantivos ocuparam somente $17,31 \%$ do tempo total da cobertura do candidato do PSDB nos noticiários. De modo semelhante à cobertura do candidato do PT, a questão da economia $(12,13 \%)$ e da segurança $(2,38 \%)$ foram os assuntos programáticos mais enfatizados pelos telejornais na cobertura de Serra, como demonstra a tabela abaixo. 
TABELA 3.6 - Assuntos da cobertura de Serra nos telejornais, Jornal Nacional e Jornal da Record $\left(1^{\circ}\right.$. e $2^{\circ}$. turnos da eleição presidencial de $2002^{81}$ ) - em porcentagem

\begin{tabular}{lcc}
\hline Categoria de assuntos & $(\%)$ & ordem \\
\hline Substantivos & 12,13 & 3 \\
economia & 0,18 & 12 \\
social em geral & 0,2 & 11 \\
educação & 0,58 & 9 \\
saúde & 0,68 & 8 \\
infra-estrutura & 0,05 & 17 \\
cultura/lazer/etnia & 2,38 & 5 \\
segurança & 0,15 & 13 \\
regiões brasileiras & 0,02 & 18 \\
meio-ambiente & 0,74 & 7 \\
assuntos estrangeiros & 0,08 & 15 \\
cidades & 0,12 & 14 \\
Forças Armadas & $\mathbf{1 7 , 3 1}$ & \\
Subtotal & & \\
Restantes & & \\
campanha & 44,32 & 1 \\
pesquisas & 23,01 & 2 \\
qualidades pessoais & 2,07 & 6 \\
ataques & 7,25 & 4 \\
mudança & 0,47 & 10 \\
pátria & 0,06 & 16 \\
Subtotal & 77,18 & \\
outros & & \\
\hline Total & 5,51 & \\
\hline
\end{tabular}

* $N$ é o total de tempo de todas as categorias

\section{“Jogo" versus "substância"}

De maneira geral, podemos afirmar que, tanto a cobertura de Lula, como a de Serra nos telejornais, enfatizou fortemente os assuntos sobre a

\footnotetext{
${ }^{81}$ De 20 de agosto a 5 de outubro de 2002, no primeiro turno; e de 14 a 26 de outubro de 2002 , no segundo turno.
} 
forma de "jogo"82 (game schema), ou seja, a campanha (agenda dos candidatos, condução de campanha e estratégias) e as pesquisas eleitorais. A categoria "jogo", em ambas as coberturas, ocupou quase que 70\% do tempo total de cada cobertura, conforme podemos observar na TAB. 3.7 ou visualizar no GRAF. 3.1. De modo inverso, pouco enfoque foi dado à categoria "substância" 83 , isto é, menos de $30 \%$ do tempo total tanto na cobertura do petista como do candidato do PSDB.

TABELA 3.7 - Cobertura eleitoral de Lula e Serra nos telejornais (Jornal Nacional e Jornal da Record), de acordo com a classificação de Patterson (1980) $-1^{\circ}$. e $2^{\circ}$. turnos da eleição presidencial de 2002

\begin{tabular}{lcc}
\hline Categorias & Cobertura Lula & Cobertura Serra \\
\hline Assuntos & tempo (\%) & tempo (\%) \\
\hline Jogo & & \\
$\quad$ campanha & 44,77 & 44,32 \\
pesquisas & 24,02 & 23,01 \\
Subtotal & $\mathbf{6 8 , 7 9}$ & $\mathbf{6 7 , 3 3}$ \\
& & \\
Substância & & \\
$\quad$ assuntos substantivos & 22,51 & 17,31 \\
$\quad$ qualidades pessoais & 1,47 & 2,07 \\
$\quad$ ataques & 3,53 & 7,25 \\
$\quad$ Subtotal & $\mathbf{2 7 , 5 1}$ & $\mathbf{2 6 , 6 3}$ \\
Outros* & 3,7 & 6,04 \\
\hline Total & $\left(\mathrm{n}=18.948^{\star \star}\right) 100$ & $\left(\mathrm{n}=19.307^{\star \star \star}\right) 100$ \\
\hline
\end{tabular}

* Estão incluídas as categorias esperança, pátria e mudança.

** $N$ é o tempo total de todas as categorias.

*** idem.

${ }^{82}$ Os assuntos foram classificados de acordo com a categorização de Patterson (1980) somente para a cobertura dos telejornais. Os assuntos em forma de jogo (game schema) foram os seguintes: pesquisas eleitorais e campanha.

${ }^{83}$ Os assuntos classificados em forma de substância (game policy) foram os seguintes: assuntos substantivos (economia, educação, saúde, segurança, social em geral, fome, infraestrutura, cultura, cidades, meio-ambiente, assuntos estrangeiros, Forças Armadas e regiões brasileiras), qualidades pessoais e ataques. 
GRÁFICO 3.1 - Cobertura de Lula e Serra nos telejornais (Jornal Nacional e Jornal da Record), de acordo com a classificação de Patterson (1980) $-1^{\circ}$. e $2^{\circ}$. turnos da eleição presidencial de 2002

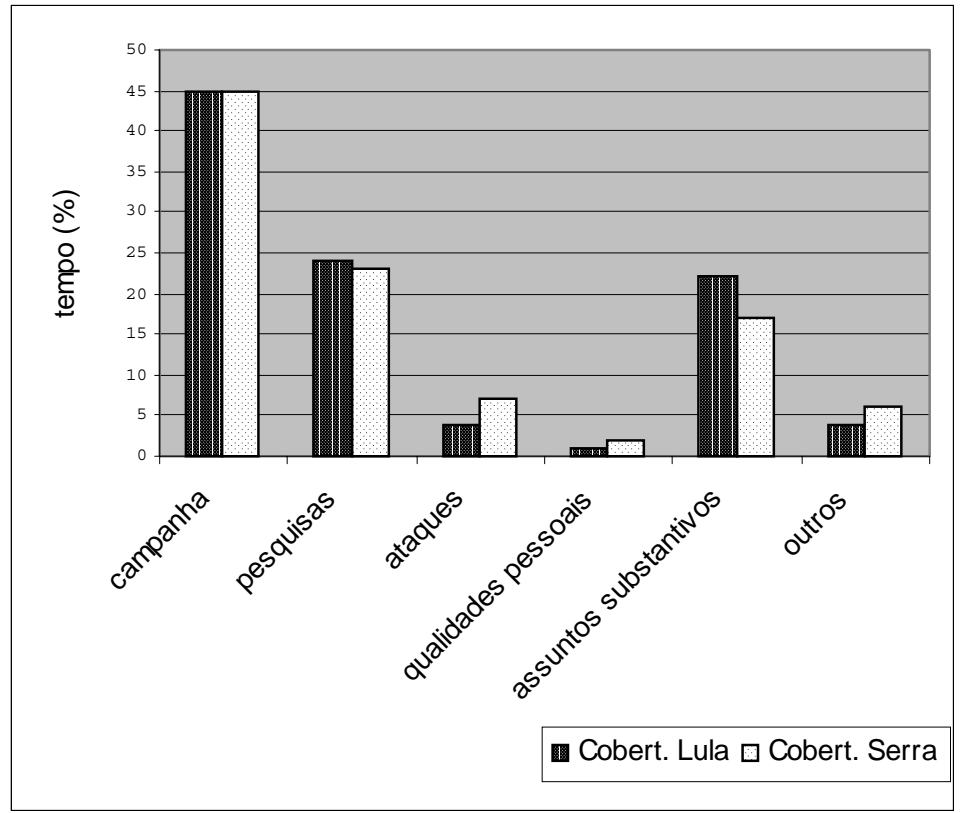

Essa maneira de condução da cobertura eleitoral dos candidatos nos telejornais brasileiros, a partir de uma ampla notoriedade dada aos assuntos sobre a condução da campanha, estratégias, agenda dos candidatos e pesquisas eleitorais, ou sob a forma de "jogo", assemelha-se bastante às 
coberturas de tevê de eleições norte-americanas. Segundo alguns autores ${ }^{84}$, nos Estados Unidos esse fato se explica porque os jornalistas seguem algumas normas de produção de notícias que dão prioridade à divulgação de assuntos que despertam mais a atenção da audiência. Este deve também ser o motivo que justifica porque as coberturas do Jornal Nacional e Jornal da Record, na eleição de 2002, deram maior destaque às atividades de campanha dos candidatos e pesquisas eleitorais.

\subsection{Conclusões}

Neste capítulo realizei o levantamento quantitativo, através da análise de conteúdo, dos assuntos da agenda do programa de governo do PT e de José Serra, da propaganda de Lula e de Serra e da cobertura dessas duas candidaturas nos telejornais, Jornal Nacional e Jornal da Record. Observei a partir dos dados que a plataforma petista concentrou sua pauta, de forma predominante, em torno do assunto economia e teve como principal proposta a geração de empregos e retomada do crescimento econômico, que seriam alcançados a partir da ruptura da política econômica em vigor. Quanto ao programa de governo de Serra, notei que, da mesma maneira do PT, o assunto economia foi o mais discutido e que a geração de empregos e o crescimento da economia foram também as principais promessas apresentadas; mas, diferentemente da plataforma petista, a plataforma tucana não previa a ruptura com o modelo econômico, apenas ajustes na política econômica como necessários para a retomada do crescimento e criação de postos de trabalhos, além do investimento em setores mais capazes de gerar empregos, como agricultura, construção civil, turismo, educação e saúde.

Em relação à propaganda de Lula na televisão, mostrei que os assuntos mais discutidos foram economia e educação, enquanto na propaganda de

\footnotetext{
${ }^{84}$ Cf. Patterson (1980, 1994), Graber (1980) e Semetko, Blumler, Gurevitch e Weaver (1991), Willians, Shapiro e Curbirth (1991).
} 
Serra, os temas relacionados à economia e saúde foram os que predominaram na pauta do candidato tucano na televisão. Especificamente, no que tange à propaganda de Lula, demonstrei que houve uma moderação da questão da mudança na política econômica, já que o candidato não defendeu em sua plataforma a ruptura global com a política econômica de FHC, como explicitado no programa do partido, mas sim uma mudança "segura" e "responsável", com base no respeito aos acordos existentes e manutenção do controle da inflação.

Finalmente, no que se refere à pauta da cobertura das candidaturas nos noticiários, observei que tanto na cobertura de Luiz Inácio Lula da Silva, como na de José Serra, os assuntos que mais ganharam destaque foram aqueles que relatavam os eventos de campanha da agenda dos candidatos e acerca das pesquisas de intenção de voto.

A conclusão é que a agenda dos programas de governo do PT e de Serra, bem como a agenda da propaganda de Lula e de Serra, esteve mais voltada para a discussão de assuntos substantivos, principalmente em torno de questões acerca da economia, enquanto a agenda da cobertura dos candidatos nos telejornais, de maneira oposta, deu mais importância aos assuntos de outra natureza, como aqueles sobre pesquisas eleitorais e relatos das atividades de campanha dos candidatos. 
Capítulo 4

\section{Agenda-setting da campanha de 2002}

\subsection{Introdução}

No capítulo anterior, além de uma análise qualitativa da agenda do PT, da propaganda de Lula e de Serra na televisão e da cobertura desses candidatos nos telejornais, fiz um levantamento quantitativo dos assuntos dessas agendas, apontando aqueles que mais receberam destaque nestes veículos. Neste último capítulo o objetivo é apresentar evidências que comprovam a hipótese de que as candidaturas Lula e Serra conseguiram transferir para a agenda das coberturas dos telejornais as prioridades de suas propagandas de televisão e que, portanto, desempenharam a função de agenda-setting na campanha presidencial de 2002. É objetivo também demonstrar que o PT logrou êxito em transpor para a agenda da propaganda de televisão de Luiz Inácio Lula da Silva a hierarquia da discussão dos assuntos de sua plataforma de governo.

O capítulo está dividido em três partes. Na primeira analiso a influência do PT na elaboração da agenda de seu candidato na propaganda de televisão. Na segunda, realizo os testes de hipóteses de que a agenda da propaganda de televisão de Lula e a de Serra estão associadas à agenda da cobertura dessas candidaturas nos telejornais, Jornal Nacional e Jornal da Record. E finalmente, na terceira parte, analiso o sentido dessa associação, ou seja, a influência da agenda dos candidatos na cobertura dos noticiários de televisão, bem como a relação inversa, qual seja, a influência desta última na agenda dos candidatos. Os testes foram feitos à luz dos dados exibidos no capítulo anterior.

\subsection{Programa do PT e propaganda de Lula na televisão}


O objetivo neste tópico é verificar em que medida o PT conseguiu transmitir a saliência de sua plataforma, divulgada em março de 2002, para a agenda da propaganda de televisão de seu candidato, Luiz Inácio Lula da Silva, veiculada durante o período de 20 de agosto a 25 de outubro.

A hipótese de associação entre as ordens dos assuntos do programa de governo petista e as ordens dos assuntos substantivos (sobre propostas) da propaganda de Lula na tevê é corroborada, uma vez que o coeficiente de spearman alcançou nível de significância. Portanto existe correspondência na hierarquia dessas agendas. Como os dados da TAB. 4.1 revelam, a maior parte das ordens das agendas se aproxima bastante.

Assim sendo, as prioridades da agenda substantiva da propaganda eleitoral de tevê do candidato Luiz Inácio Lula da Silva foram semelhantes as da agenda dos assuntos da plataforma do PT. Como a plataforma petista foi divulgada primeiro, podemos inferir que a ordem da pauta partidária foi transferida para a agenda discutida na televisão pela propaganda.

TABELA 4.1 - Assuntos substantivos do programa de governo do PT e da propaganda eleitoral de Lula na televisão $-1^{\circ}$. e $2^{\circ}$. turnos da eleição presidencial de 2002 (13 assuntos)

\begin{tabular}{|c|c|c|c|c|}
\hline Assuntos & Programa PT & & Propaganda Lula & \\
\hline Categorias & $(\%)$ & ordem & $(\%)$ & ordem \\
\hline economia & 60,43 & 1 & 44,63 & 1 \\
\hline social em geral & 12,44 & 2 & 4,63 & 5 \\
\hline educação & 3,79 & 3 & 18,16 & 2 \\
\hline cultura/lazer/etnias & 3,08 & 4 & 0,9 & 8 \\
\hline infra-estrutura & 2,96 & 5 & 2,44 & 7 \\
\hline fome & 2,73 & 6 & 3,85 & 6 \\
\hline segurança & 2,13 & 7 & 5,88 & 4 \\
\hline regiões brasileiras & 1,9 & 8 & 0 & 12,5 \\
\hline saúde & 1,3 & 9 & 12,74 & 3 \\
\hline meio-ambiente & 1,18 & 10 & 0,06 & 10 \\
\hline assuntos estrangeiros & 1,07 & 11 & 0 & 12,5 \\
\hline cidades & 0,71 & 12 & 0,19 & 9 \\
\hline Forças Armadas & 0 & 13 & 0,01 & 11 \\
\hline outros* & 6,28 & & 6,51 & \\
\hline Total & $\left(n=844^{\star \star}\right) 100$ & & $\left(n=16.606^{\star \star \star}\right) 100$ & \\
\hline
\end{tabular}


*A categoria outros não foi incluída no cálculo da correlação.

** Trata-se do total de menções de todas as categorias.

*** Trata-se do total de tempo de todas as categorias.

GRÁFICO 4.1 - Gráfico da correlação do programa do PT e da propaganda de Lula na televisão

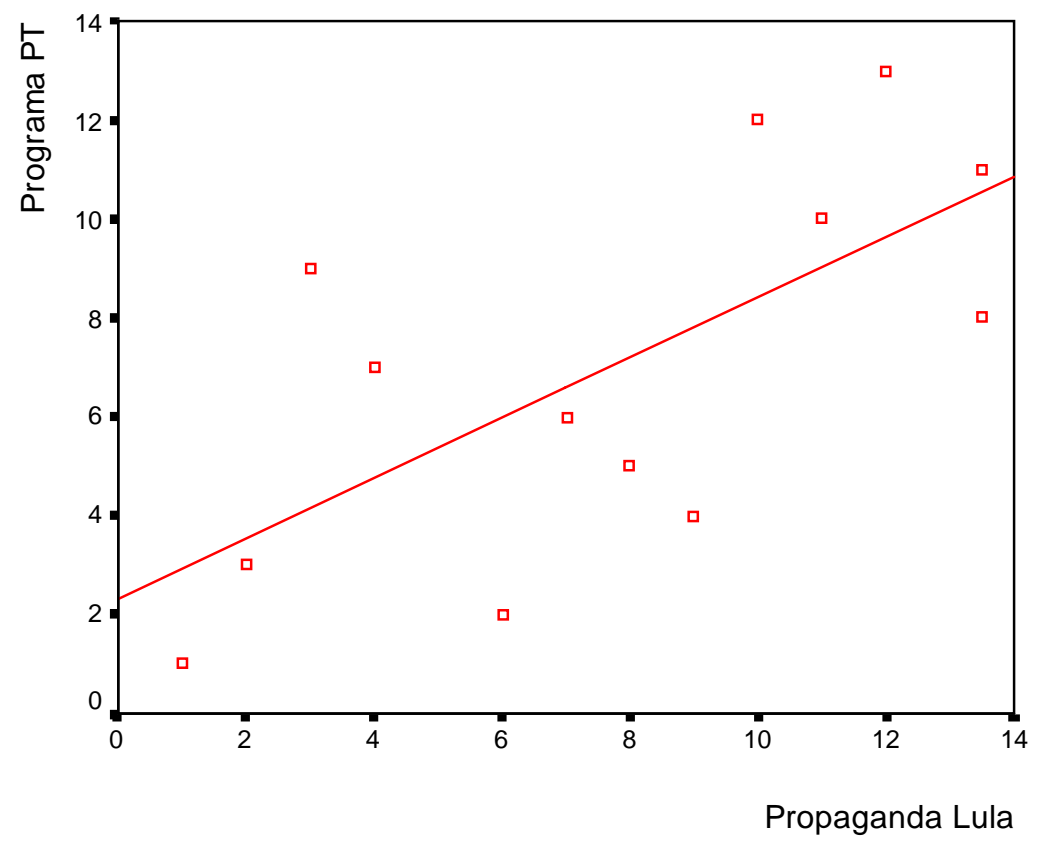

De acordo com o GRAF. 4.1, extraído a partir do cálculo da associação entre a agenda do programa de governo do PT e a agenda da propaganda de Lula, podemos visualizar que há uma certa aproximação dos pontos que representam as ordens dos assuntos das duas agendas observadas em relação à reta imaginária.

A discussão acerca da economia predominou tanto na pauta do programa do PT como na propaganda de televisão do candidato Luiz Inácio Lula da Silva. O governo Fernando Henrique Cardoso foi criticado com 
veemência pela plataforma petista, que o acusou de ter sido responsável pelo baixo crescimento econômico e desemprego no país:

Uma característica central do modelo implantado nos anos 1990 diz respeito à dependência à vulnerabilidade externas da economia brasileira (...) Nesse contexto, a estabilidade de preços - única prioridade do atual modelo econômico - foi alcançada com o sacrifício de outros objetivos relevantes como o crescimento econômico, o nível de emprego, a solidez das finanças públicas e das contas externas (...) No século $X X$, somente os governos de Venceslau Brás na Primeira Guerra Mundial, Washington Luiz na crise de 1929 e governo Collor fizeram o país crescer menos que o período de FHC, o qual apresenta uma taxa média de apenas $2,3 \%$ do PIB ao ano.

De maneira similar à plataforma do PT, Lula, no horário eleitoral de televisão e nos spots, responsabilizou o governo FHC pelas reduzidas taxas de crescimento econômico e pela situação de desemprego que o país presenciava naquele ano eleitoral: "Temos que mudar essa política econômica perversa, que paralisou nossa economia, aumentou nossa dependência externa, fragilizou as nossas empresas e causou o maior desemprego de nossa história nos últimos 50 anos".

Há também sintonia entre o documento partidário e o discurso da propaganda de Lula na televisão no que tange à ênfase das propostas de crescimento da economia e a geração de empregos, bem como das que salientam o crescimento econômico sustentado e a diminuição da dependência ao capital estrangeiro. Entretanto, há uma divergência relevante entre o programa do PT e a propaganda de Lula. A falta de sintonia é que o partido advogava a necessidade de uma ruptura efetiva com o modelo econômico vigente, através do rompimento do acordo com o Fundo Monetário Internacional (FMI), enquanto, diferentemente, a propaganda de Lula na tevê propunha uma "mudança responsável" e "segura", sem quebra de contratos: "como tenho afirmado durante toda essa campanha, vamos honrar todos os compromissos assumidos pelo governo brasileiro, vamos manter a inflação sob controle e as metas de superávit que forem necessários". Assim sendo, a propaganda de Lula suprimiu de sua plataforma divulgada na tevê a defesa do 
rompimento com o FMI, uma vez que tal postura havia contribuído para a emergência da crise econômica de junho e assustado o mercado financeiro, além de ter servido de combustível para os adversários de Lula afirmarem que o candidato petista levaria o Brasil ao retorno da inflação e a uma situação parecida com a da Argentina.

Quanto à questão social em geral, tanto o documento partidário como o discurso de Lula na televisão defendia a necessidade de se colocar o social como eixo do desenvolvimento econômico brasileiro e, ao mesmo tempo, criticava o governo FHC por não ter feito isso nos oitos anos de mandato.

Em relação às questões sociais específicas, como educação, fome, saúde e segurança, as principais posições assumidas no programa de governo do partido foram mantidas na plataforma divulgada na tevê. Tanto no documento partidário como na tevê estiveram presentes as seguintes propostas: uma grande ênfase na questão da qualidade do ensino público e na defesa da diminuição da evasão escolar, além da proposta de ampliação do projeto "Bolsa - Escola" da prefeitura de São Paulo para todo o Brasil; projeto de ampliação dos benefícios sociais existentes, além da necessidade da distribuição de renda, para que a população passasse a ter dinheiro para comprar comida; medidas para ampliar e facilitar o acesso da população aos medicamentos essenciais e de uso continuado e o impulso às políticas de saúde preventiva, além da melhora da qualidade dos serviços públicos de saúde prestados; amplo programa de combate à violência, ao narcotráfico e ao crime organizado, a partir de uma nova concepção de segurança pública, envolvendo planejamento, além de investimentos em qualificação técnica e integração do sistema policial.

As propostas para outras áreas, como cultura e infra-estrutura também foram semelhantes na agenda do programa do PT e na propaganda de Lula. Particularmente em relação às propostas para a infra-estrutura, a ênfase recaiu no incentivo à construção de moradias populares, com o intuito de assegurar a estabilidade familiar. Também foi proposto, nessa área, um projeto de reforma 
urbana que visava dar segurança à propriedade aos terrenos na periferia das grandes cidades e viabilizar o financiamento imobiliário à construção civil.

Em suma, a hierarquia dos assuntos da agenda do PT e da propaganda de televisão de Lula é bastante próxima uma da outra. Como o programa do partido foi lançado bem antes da propaganda e tendo em conta a relação mais orgânica do candidato com seu partido pode-se afirmar que houve uma influência do partido no ordenamento das propostas apresentadas por Lula na propaganda de televisão, durante o período da campanha eleitoral. Isso não significa que não tenha havido um grau de autonomia da candidatura Lula em relação ao partido quanto ao conteúdo discutido, haja vista que a questão da ruptura estrutural da política econômica vigente, defendida no programa do PT, não permaneceu na propaganda de Lula na televisão. Tanto no horário eleitoral como nos spots, o candidato petista era a favor de uma mudança "segura", admitindo assim, paradoxalmente, uma "certa continuidade" do modelo econômico de FHC.

Portanto, é importante ressaltar que o modelo das prioridades utilizado neste trabalho para a verificação de que o programa do PT influenciou a agenda da propaganda de Lula tem um limite, pois verifica a associação entre as saliências dos assuntos discutidos nas duas pautas, porém não dá conta de detectar a questão mais específica sobre como as propostas foram discutidas no documento partidário e na propaganda.

\subsection{Associação entre propaganda de televisão e cobertura dos noticiários}

Nesta seção o objetivo é medir a associação ${ }^{85}$ entre a agenda de Lula, veiculada na propaganda de televisão, e o conteúdo a cobertura dessa candidatura nos telejornais, bem como verificar a associação entre a agenda da propaganda de Serra na televisão e o conteúdo da cobertura do candidato

\footnotetext{
${ }^{85}$ Vale lembrar que as associações são baseadas no spearman rho, que leva em conta o ordenamento das prioridades dos assuntos das agendas e não as porcentagens.
} 
tucano nos noticiários. Realizo testes de associação entre as ordens ${ }^{86}$ dos assuntos das agendas, considerando o período eleitoral em que a propaganda dos candidatos e as coberturas foram ao ar entre 20 de agosto a 26 de outubro de $2002^{87}$. Cada teste é efetuado de três maneiras distintas, de acordo com a natureza dos assuntos. Primeiramente considero todos os assuntos das agendas, em seguida somente os assuntos substantivos e, por fim, somente os assuntos restantes. Cada teste é realizado de maneira independente.

\section{Associação entre a propaganda de Lula e cobertura de Lula nos telejornais}

A hipótese de associação entre as ordens de todos os assuntos da agenda da propaganda de televisão de Luiz Inácio Lula da Silva e as ordens de todos assuntos da agenda da cobertura dessa candidatura nos telejornais, Jornal Nacional e Jornal da Record, é rejeitada, pois o $r$ de spearman é muito fraco $(+0,26)$ e não alcançou o nível de significância (ver TAB. 4.2).

Essa fraca associação deveu-se às profundas diferenças entre as prioridades temáticas da cobertura de tevê e da propaganda de Lula, quando levado em conta todos os assuntos desses dois veículos. As distinções mais marcantes concentraram-se nos assuntos substantivos, referentes à educação, fome, saúde e assuntos estrangeiros, e nos assuntos restantes acerca das pesquisas, qualidades pessoais, ataques, mudança, esperança e pátria. Ou dizendo de outra maneira, a propaganda do candidato do PT centrou-se na discussão dos assuntos acerca da saúde, educação, fome e no enfoque sobre a esperança, pátria e mudança, enquanto a cobertura dos telejornais deu maior

\footnotetext{
${ }^{86}$ As ordens são dos tempos dos assuntos.

${ }^{87}$ Para a propaganda eleitoral dos candidatos, os períodos considerados foram os seguintes: de 20 de agosto a 3 de outubro no $1^{\circ}$. turno e de 14 a 25 de outubro de 2002, para o $2^{\circ}$ turno. Para a cobertura dos telejornais, os períodos foram: de 20 de agosto a 5 de outubro, no $1^{\circ}$. turno e de 14 a 26 de outubro de 2002 , no $2^{\circ}$. turno.
} 
preferência aos assuntos estrangeiros, campanha, pesquisas e aos ataques de Lula contra Serra (ver TAB. 4.2).

TABELA 4.2 - Todos os assuntos da propaganda de Lula na televisão e da cobertura eleitoral de Lula nos telejornais, Jornal Nacional e Jornal da Record $-1^{\circ}$. e $2^{\circ}$. turnos da eleição presidencial de 2002 (20 assuntos)

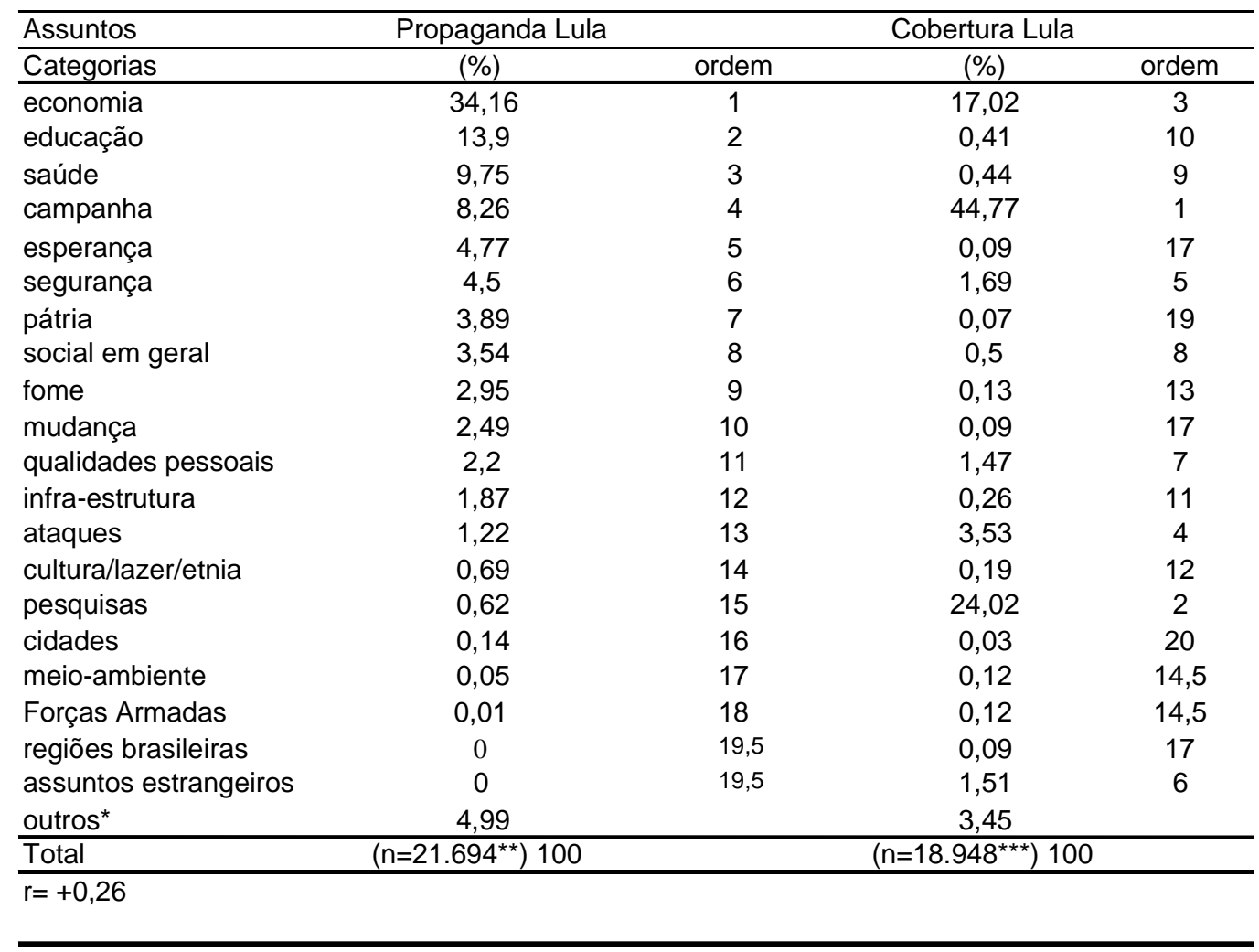


* A categoria outros não foi incluída no cálculo da correlação.

** $N$ é o total de tempo de todas as categorias.

*** Idem.

GRÁFICO 4.2 - Gráfico da correlação de todos os assuntos da propaganda de Lula e da cobertura de Lula nos telejornais

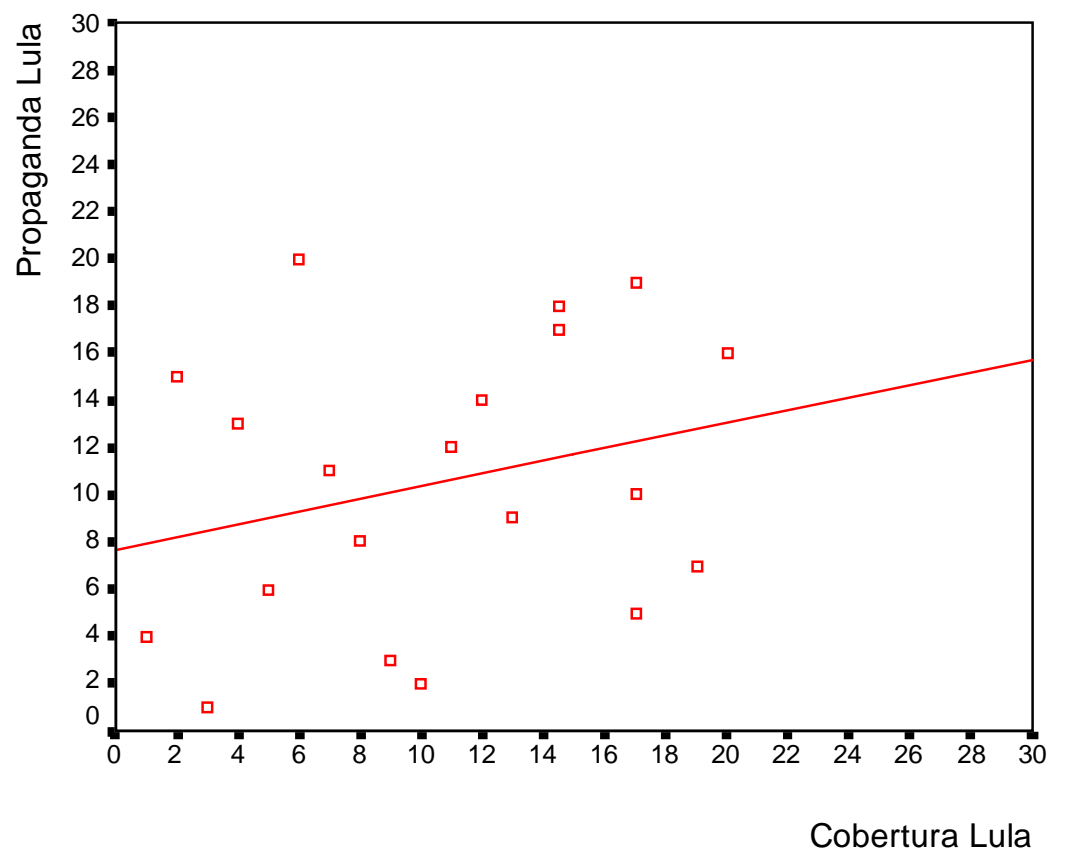

Quando realizo o teste de associação entre as ordens dos assuntos da propaganda eleitoral de Lula na televisão e as ordens da cobertura dos telejornais dessa candidatura, incluindo apenas os assuntos substantivos economia, educação, saúde, segurança, social em geral, fome, assuntos estrangeiros, infra-estrutura, cultura/lazer/etnia, cidades, meio-ambiente, Forças Armadas e regiões brasileiras - a hipótese de associação das prioridades dos assuntos é corroborada (ver TAB. 4.3).

TABELA 4.3 - Assuntos substantivos da propaganda de Lula na televisão e da cobertura eleitoral de Lula nos telejornais, Jornal Nacional e Jornal da Record $-1^{\circ}$. e $2^{\circ}$. turnos da eleição presidencial de 2002 (13 assuntos) 


\begin{tabular}{|c|c|c|c|c|}
\hline Assuntos & Propaganda Lula & & Cobertura Lula & \\
\hline Categorias & (\%) & ordem & (\%) & ordem \\
\hline economia & 47,74 & 1 & 75,69 & 1 \\
\hline educação & 19,42 & 2 & 1,81 & 6 \\
\hline saúde & 13,62 & 3 & 1,95 & 5 \\
\hline segurança & 6,29 & 4 & 7,51 & 2 \\
\hline social em geral & 4,95 & 5 & 2,13 & 4 \\
\hline fome & 4,12 & 6 & 0,56 & 9 \\
\hline infra-estrutura & 2,61 & 7 & 1,15 & 7 \\
\hline cultura/lazer/etnia & 0,97 & 8 & 0,87 & 8 \\
\hline cidades & 0,2 & 9 & 0,12 & 13 \\
\hline meio-ambiente & 0,07 & 10 & 0,54 & 10,5 \\
\hline Forças Armadas & 0,01 & 11 & 0,54 & 10,5 \\
\hline assuntos estrangeiros & 0 & 12,5 & 6,71 & 3 \\
\hline regiões brasileiras & 0 & 12,5 & 0,42 & 12 \\
\hline Total & $\left(n=15.525^{*}\right) 100$ & & $\left(n=4.261^{\star \star}\right) 100$ & \\
\hline
\end{tabular}

* $N$ é o total de tempo de todas as categorias referentes aos assuntos substantivos.

** Idem.

GRÁFICO 4.3 - Gráfico dos assuntos substantivos da propaganda de Lula e da cobertura de Lula nos telejornais

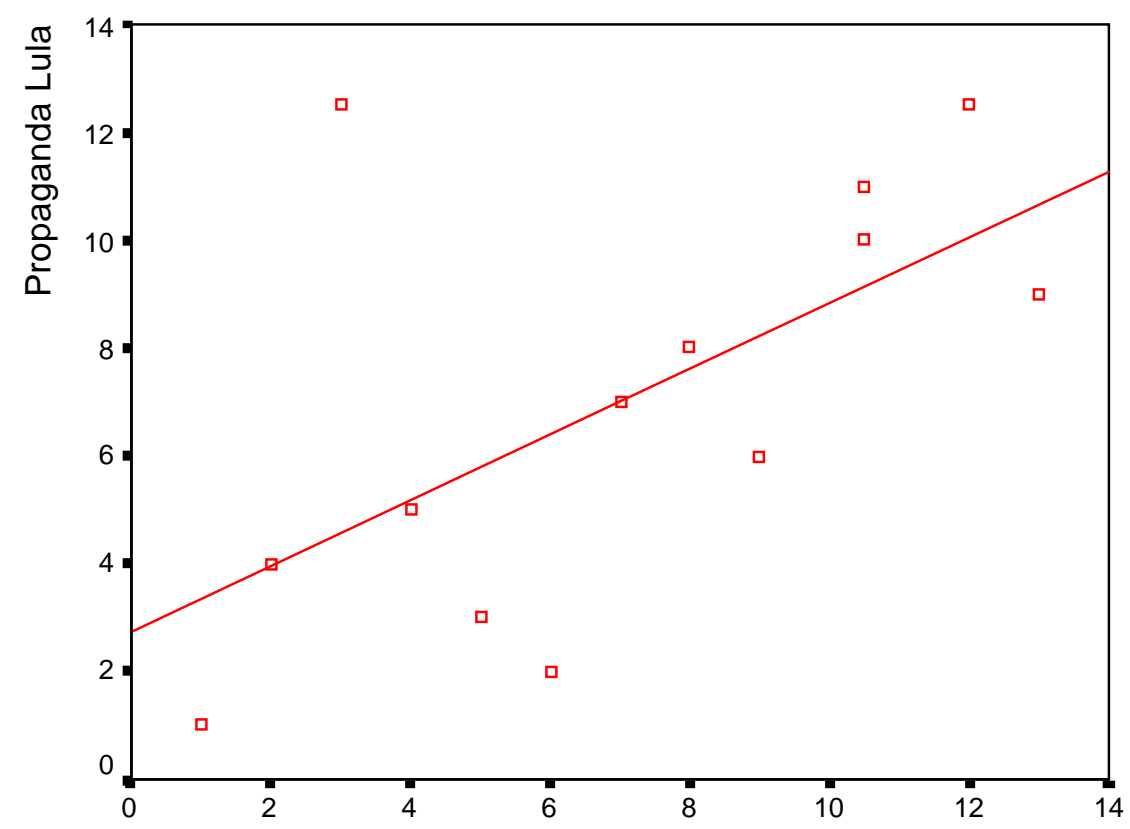


Como ilustra a TAB. 4.3, as ordens das preferências dos assuntos relativos às propostas dos candidatos na propaganda são quase as mesmas da agenda da cobertura de Luiz Inácio Lula da Silva. O GRAF. 4.3 torna mais visível essa aproximação entre as prioridades das duas agendas, uma vez que os pontos, referentes às ordens de destaque dos assuntos, estão bem próximos à reta imaginária.

No entanto, a confirmação da hipótese não se repete quando realizo a correlação entre as ordens dos assuntos restantes da propaganda de Lula e as ordens dos assuntos restantes da agenda da cobertura eleitoral de Lula nos telejornais, uma vez que a correlação obtida é negativa $(-0,18)$.

Como podemos ver na TAB. 4.4, a inversão das ordens dos assuntos restantes explica-se porque a cobertura dos telejornais focalizou mais a atenção nos assuntos sobre pesquisas eleitorais e ataques. De maneira oposta, a propaganda de Lula privilegiou os assuntos sobre esperança, pátria e mudança, discutindo de maneira restrita as pesquisas eleitorais e ataques - já que, neste último caso, a estratégia adotada pela equipe de campanha foi de não atacar os adversários porque o candidato petista encontrava-se na frente das pesquisas eleitorais.

TABELA 4.4 - Assuntos restantes da propaganda eleitoral de Lula na televisão e da cobertura eleitoral de Lula nos telejornais, Jornal Nacional e Jornal da Record $-1^{\circ}$. e $2^{\circ}$. turnos da eleição presidencial de 2002 
(7 assuntos)

\begin{tabular}{lcccc}
\hline Assuntos & Propaganda Lula & \multicolumn{3}{c}{ Cobertura Lula } \\
\hline Categorias & $(\%)$ & ordem & $(\%)$ & ordem \\
\hline campanha & 35,24 & 1 & 60,46 & 1 \\
esperança & 20,32 & 2 & 0,13 & 5,5 \\
pátria & 16,59 & 3 & 0,09 & 7 \\
mudança & 10,63 & 4 & 0,13 & 5,5 \\
qualidades pessoais & 9,4 & 5 & 1,99 & 4 \\
ataques & 5,19 & 6 & 4,77 & 3 \\
pesquisas & 2,63 & 7 & 32,43 & 2 \\
\hline Total & $\left(\mathrm{n}=5.088^{\star}\right) 100$ & \multicolumn{4}{c}{$\left(\mathrm{n}=14.034^{\star \star}\right) 100$} \\
\hline
\end{tabular}

$r=-0,18$

* $N$ é o total de tempo de todas as categorias referentes aos assuntos restantes.

** Idem.

GRÁFICO 4.4 - Gráfico da correlação dos assuntos restantes da propaganda de Lula e da cobertura de Lula nos telejornais

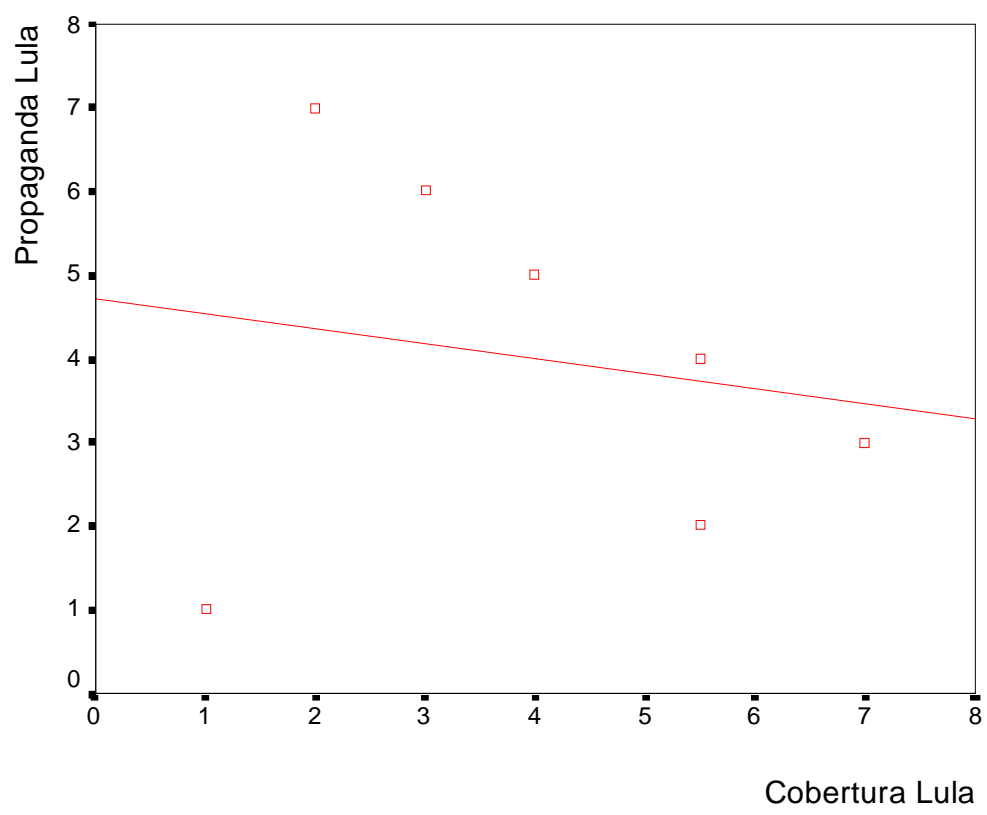

Em síntese, observei que existe associação entre a agenda da propaganda de Lula na televisão e a cobertura do candidato petista nos 
telejornais, Jornal Nacional e Jornal da Record, só quando comparo a hierarquia dos assuntos substantivos de ambas agendas, já que na ocasião em que confronto todos os assuntos ou somente os restantes, o coeficiente de spearman não alcança o nível de significância para que a hipótese de associação ou semelhança entre as preferências dessas duas agendas seja aceita. Como já foi dito anteriormente, a explicação dada à cobertura jornalística, mais voltada para assuntos em forma de jogo (andamento da campanha e pesquisas) e de conflitos, deve-se aos critérios de noticiabilidade (presentes na camada mais próxima do núcleo da "cebola teórica"88), que normalmente dizem aos jornalistas quais os assuntos mais noticiosos a serem divulgados durante a campanha eleitoral, como os de natureza mais dinâmica e que despertam, por isso, mais atenção junto às audiências.

\section{Associação entre a propaganda de José Serra e cobertura de Serra nos telejornais}

Quando realizo a correlação entre todos os assuntos da propaganda de Serra na televisão e todos os assuntos dessa candidatura na cobertura eleitoral dos telejornais, admitindo todo o período da campanha na tevê, entre 20 de agosto a 26 de outubro, a hipótese de associação entre as agendas é aceita $(+0,76)$. Ou seja, pode-se dizer que existe uma correspondência das prioridades dos assuntos entre as duas agendas destes dois veículos.

De acordo com a TAB. 4.5, observo que há predominância das ordens parecidas dos tempos dos assuntos das agendas comparadas, embora haja também algumas diferenças nas ordens dos assuntos sobre saúde e qualidades pessoais, mais discutidos pela propaganda tucana do que pela cobertura dos telejornais, além do destaque do tópico a respeito da discussão sobre pesquisas, que ganhou o topo da pauta dos jornalistas e o $10^{\circ}$. lugar na agenda da propaganda do candidato do PSDB.

\footnotetext{
${ }^{88}$ Ver QUADRO 1.4, p. 17.
} 
Tabela 4.5 - Todos os assuntos da propaganda de Serra na televisão e da cobertura eleitoral de Serra nos telejornais, Jornal Nacional e Jornal da Record $-1^{\circ}$. e $2^{\circ}$. turnos da eleição presidencial de 2002 (19 assuntos)

\begin{tabular}{lcccc}
\hline \multicolumn{1}{l}{ Assuntos } & Propaganda Serra & & Cobertura Serra & \\
\hline Categorias & $(\%)$ & ordem & $(\%)$ & ordem \\
\hline economia & 32,3 & 1 & 12,13 & 3 \\
qualidades pessoais & 12,32 & 2 & 2,07 & 6 \\
ataques & 8,81 & 3 & 7,25 & 4 \\
saúde & 7,66 & 4 & 0,58 & 9 \\
campanha & 6,43 & 5 & 44,32 & 1 \\
segurança & 5,69 & 6 & 2,38 & 5 \\
social em geral & 5,53 & 7 & 0,18 & 12 \\
educação & 4,31 & 8,5 & 0,2 & 11 \\
mudança & 4,31 & 8,5 & 0,47 & 10 \\
pesquisas & 1,98 & 10 & 23,01 & 2 \\
infra-estrutura & 1,45 & 11 & 0,68 & 8 \\
cidades & 1,03 & 12 & 0,08 & 15 \\
regiões brasileiras & 0,66 & 13 & 0,15 & 13 \\
assuntos estrangeiros & 0,44 & 14 & 0,74 & 7 \\
meio-ambiente & 0,14 & 15 & 0,02 & 18 \\
pátria & 0,11 & 16 & 0,06 & 16 \\
fome & 0,09 & 17 & 0 & 19 \\
cultura/lazer/etnias & 0,04 & 18 & 0,05 & 17 \\
Forças Armadas & 0 & 19 & 0,12 & 14 \\
outros* & 6,7 & & 5,51 & \\
\hline Total & $\left(\mathrm{n}=27.451^{\star \star}\right)$ 100 & & $\left(\mathrm{n}=19.307^{\star \star \star *}\right) 100$ & \\
\hline r = 0,76 & & & & \\
correlação é significante ao nível 0,01 & & & \\
\hline
\end{tabular}

* A categoria outros não foi incluída no cálculo da correlação.

** $N$ é o total de tempo de todas as categorias.

$\star \star \star$ Idem.

GRÁFICO 4.5 - Gráfico da correlação de todos os assuntos da propaganda de Serra e da cobertura de Serra nos telejornais

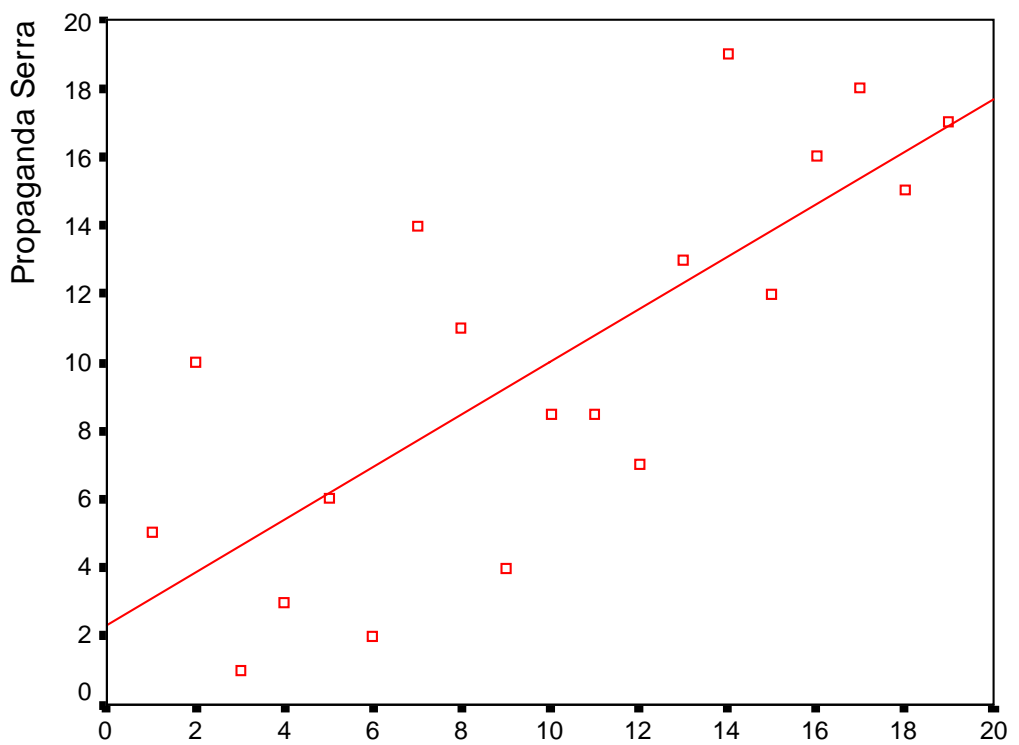


Já a hipótese de associação entre a ordem dos assuntos substantivos da agenda da propaganda eleitoral de Serra e a ordem dos assuntos, dessa mesma natureza, da cobertura tucana também é confirmada, com o coeficiente de associação de $+0,74$, como se pode ver na TAB. 4.6, logo abaixo.

A mesma ênfase atribuída aos assuntos substantivos na agenda da propaganda de Serra também foi dada aos assuntos substantivos da cobertura do candidato tucano nos telejornais. No GRAF. 4.6 a proximidade das ordens dos assuntos das duas agendas pode ser notada de maneira mais nítida. Como se pode notar, os pontos estão próximos à reta imaginária.

Tabela 4.6 - Assuntos substantivos da propaganda de Serra na televisão e da cobertura eleitoral de Serra nos telejornais, Jornal Nacional e Jornal da Record $-1^{\circ}$. e $2^{\circ}$. turnos da eleição presidencial de 2002 (13 assuntos)

\begin{tabular}{|c|c|c|c|c|}
\hline Assuntos & Propaganda Serra & & Cobertura Serra & \\
\hline Categorias & (\%) & ordem & $(\%)$ & ordem \\
\hline economia & 54,42 & 1 & 70,05 & 1 \\
\hline saúde & 12,92 & 2 & 3,35 & 5 \\
\hline segurança & 9,58 & 3 & 13,76 & 2 \\
\hline social em geral & 9,31 & 4 & 1,05 & 7 \\
\hline educação & 7,27 & 5 & 1,13 & 6 \\
\hline infra-estrutura & 2,45 & 6 & 3,92 & 4 \\
\hline cidades & 1,73 & 7 & 0,45 & 10 \\
\hline regiões brasileiras & 1,12 & 8 & 0,9 & 8 \\
\hline assuntos estrangeiros & 0,75 & 9 & 4,28 & 3 \\
\hline meio-ambiente & 0,24 & 10 & 0,09 & 12 \\
\hline fome & 0,15 & 11 & 0 & 13 \\
\hline cultura/lazer/etnia & 0,06 & 12 & 0,3 & 11 \\
\hline Forças Armadas & 0 & 13 & 0,72 & 9 \\
\hline Total & $\left(n=16.289^{*}\right) 100$ & & $\left(n=3.343^{\star *}\right) 100$ & \\
\hline
\end{tabular}

* $N$ é o total de tempo de todas as categorias referentes aos assuntos substantivos. 
GRÁFICO 4.6 - Gráfico da correlação dos assuntos substantivos da propaganda de Serra e da cobertura de Serra nos telejornais

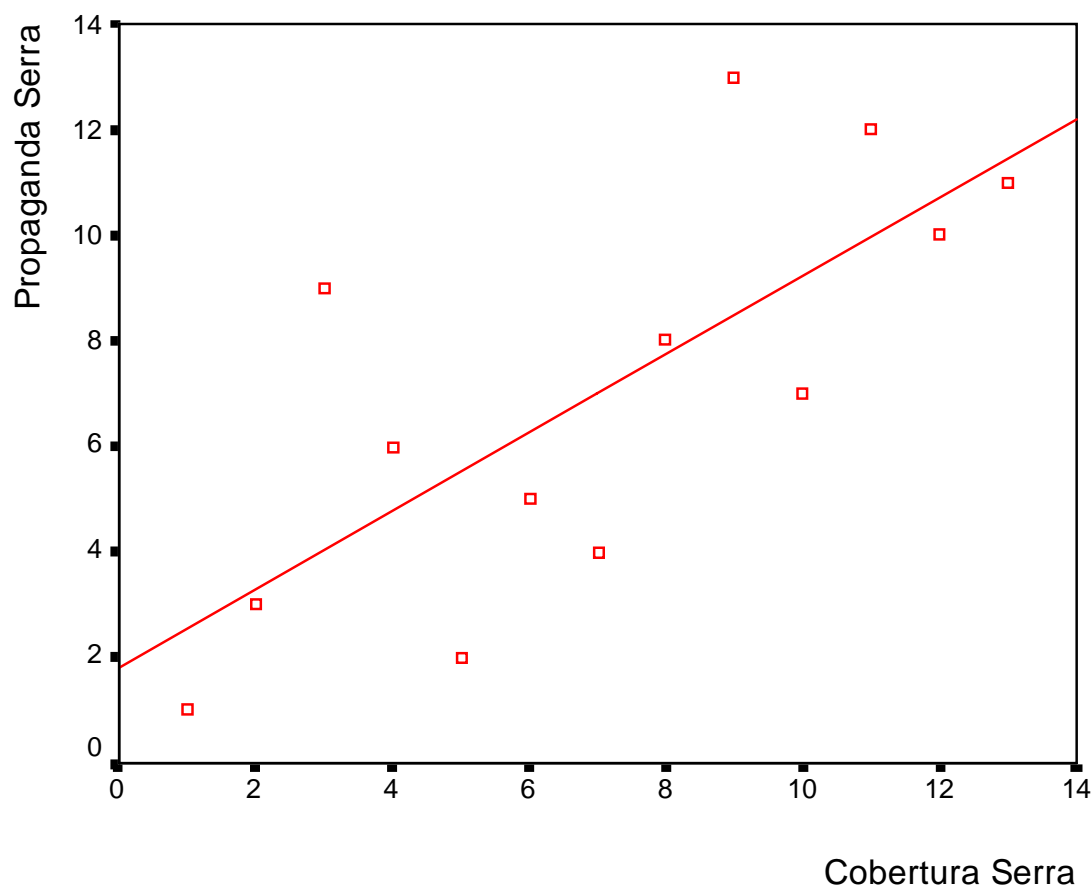

Mas quando realizo a correlação de postos levando em conta somente os assuntos restantes da propaganda de tevê e os assuntos restantes da 
cobertura de Serra nos telejornais, a hipótese de associação é rejeitada, dado que o coeficiente de spearman $(+0,31)$ não alcança o nível de significância.

A rejeição da hipótese de associação entre essas duas agendas pode ser explicada pelo enfoque dos jornalistas nos assuntos de alto valor noticioso, como aqueles sobre informação da agenda da campanha dos candidatos, estratégias e pesquisas eleitorais (ver TAB. 4.7), enquanto a propaganda de Serra centrou mais a discussão nos assuntos acerca das qualidades pessoais. Como a diferença entre as ordens destes assuntos (campanha, pesquisas e qualidades pessoais) foi muito acentuada, o coeficiente de spearman não apresentou significância e a hipótese de associação entre as prioridades dos assuntos restantes da propaganda de tevê de Serra e da cobertura desta candidatura nos noticiários foi rejeitada.

Tabela 4.7 - Assuntos restantes da propaganda eleitoral de Serra na televisão e da cobertura eleitoral de Serra nos telejornais (Jornal Nacional e Jornal da Record) $-1^{\circ}$. e $2^{\circ}$. turnos da eleição presidencial de 2002 (6 assuntos)

\begin{tabular}{lcccc}
\hline Assuntos & Propaganda Serra & \multicolumn{3}{c}{ Cobertura Serra } \\
\hline Categorias & $(\%)$ & ordem & $(\%)$ & ordem \\
\hline qualidades pessoais & 36,28 & 1 & 2,69 & 4 \\
ataques & 25,95 & 2 & 9,39 & 3 \\
campanha & 18,92 & 3 & 57,43 & 1 \\
mudança & 12,7 & 4 & 0,61 & 5 \\
pesquisas & 5,83 & 5 & 29,81 & 2 \\
pátria & 0,32 & 6 & 0,07 & 6 \\
\hline Total & $\left(\mathrm{n}=9.322^{\star}\right) 100$ & & $\left(\mathrm{n}=14.901^{\star *}\right) 100$ & \\
\hline $\mathrm{r}=+0,31$ & & & & \\
\end{tabular}

* $N$ é o total de tempo de todas as categorias referentes aos assuntos restantes.

** Idem.

GRÁFICO 4.7 - Gráfico da correlação dos assuntos restantes da propaganda de Serra e da cobertura de Serra nos telejornais

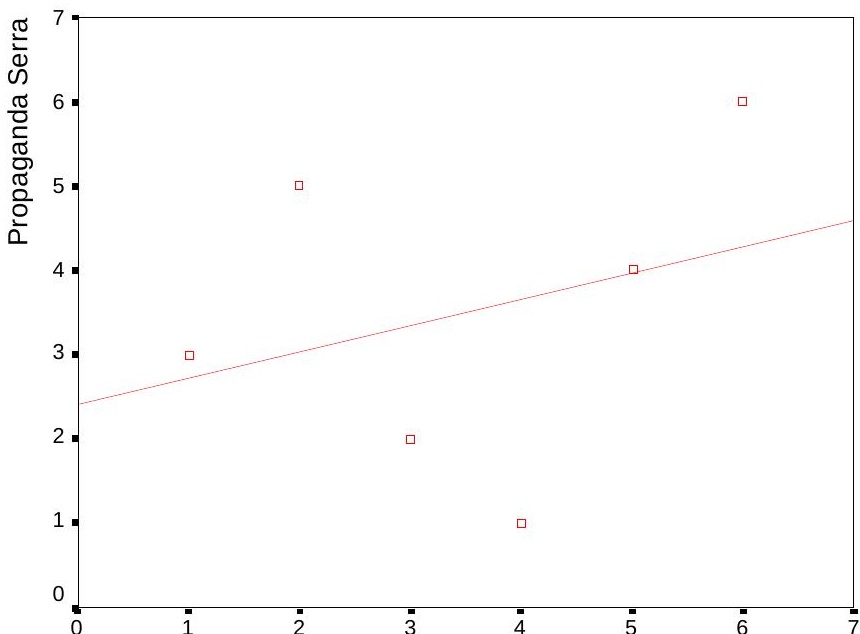


Em resumo, a conclusão é a de que existe associação entre a hierarquia dos assuntos da agenda da propaganda de televisão de Serra e a ordem dos assuntos da agenda da cobertura eleitoral tucana nos noticiários de televisão. É importante lembrar, no entanto, que a hipótese de associação é aceita quando comparo todos assuntos e os assuntos substantivos, mas quando confronto apenas os assuntos restantes das duas pautas, a hipótese é rejeitada.

\subsection{Cross-lagged correlations ${ }^{89}$}

Nesta seção realizo o exame da influência da agenda da propaganda de tevê dos candidatos Lula e Serra na elaboração da agenda dos telejornais, através da observação da transferência da ênfase dos assuntos. Também efetuo a análise inversa, isto é, verifico se os telejornais conseguiram influenciar a ordenação da pauta da propaganda de televisão dos candidatos, de acordo com time-lag ou intervalos temporais pré-determinados.

Primeiramente, foram efetuados os testes de hipóteses, através do cálculo do $r$ do $\operatorname{spearman}^{90}$, para a verificação de influência da agenda da propaganda eleitoral dos candidatos na agenda da cobertura dos noticiários de televisão. Os testes levaram em conta a adoção de intervalos temporais (timelag) e foram realizados de três maneiras: através de uma "bateria" de 24 correlações para todos os assuntos; mediante a realização de 20 correlações

\footnotetext{
${ }^{89}$ Ver Quadro 1.5, p. 32.

${ }^{90}$ Vale lembrar, novamente, que as associações são baseadas no spearman rho, que leva em conta o ordenamento das prioridades dos assuntos das agendas e não as porcentagens.
} 
somente considerando os assuntos substantivos; e por meio de uma "bateria" de 20 correlações apenas avaliando os assuntos restantes.

Nos testes de correlações entre todos os assuntos das agendas, o timelag ótimo foi de três dias para a propaganda eleitoral de televisão e de seis dias para a cobertura eleitoral dos telejornais. No entanto, o time-lag referente aos testes de hipóteses dos assuntos substantivos e assuntos restantes foi de cinco dias para a propaganda eleitoral de televisão e de dez dias para a cobertura dos telejornais $^{91}$.

O critério utilizado para a aceitação ou rejeição das hipóteses foi a porcentagem de correlações significantes de cada "bateria". Isto é, uma hipótese foi aceita quando o número de correlações significantes, de um conjunto delas, foi igual ou superior a 50\%; abaixo dessa porcentagem, entretanto, a hipótese foi rejeitada.

Em seguida, foram realizados os testes para a verificação da relação inversa, isto é, da influência da cobertura das candidaturas nas propagandas de televisão. Nestes foram adotados intervalos temporais de dez dias para a cobertura eleitoral e de cinco dias para a propaganda na comparação dos assuntos substantivos das duas agendas. No entanto, no confronto entre todos os assuntos de ambas as agendas o intervalo adotado foi de seis dias para a cobertura e de três para a propaganda de tevê. Quanto aos critérios para aceitação ou rejeição das hipóteses, os mesmos utilizados no caso dos testes da observação da influência da propaganda nos telejornais foram considerados.

\footnotetext{
${ }^{91}$ Agrupou-se cinco dias da propaganda eleitoral de televisão de uma determinada candidatura e realizou-se a correlação entre a hierarquia da agenda de assuntos desse intervalo e a ordenação da agenda de dez dias da cobertura eleitoral dos telejornais, Jornal Nacional e Jornal da Record. Por exemplo, no primeiro turno, a propaganda de tevê foi ao ar somente às terças, quintas-feiras e aos sábados, enquanto a cobertura de segunda a sábado. Portanto, juntou-se os dias 20 (terça), 22 (quinta), 24 (sábado), 27 (terça) e 29 (quinta) da propaganda eleitoral de tevê, levantando a agenda destes cinco dias e correlacionou-se com a agenda dos dias 21(quarta), 22 (quinta), 23 (sexta), 24 (sábado), 26 (segunda), 27(terça-feira), 28 (quarta), 29 (quinta), 30 (sexta) e 31 (sábado). Este time-lag (considerado a duração do efeito ótimo) foi decidido depois de havermos utilizado os time-lag de 1 dia e 2 dias.
} 
A hipótese de influência da agenda de Lula na agenda dos noticiários é rejeitada quando considero todos os assuntos das duas agendas. Em 24 correlações, somente uma $(4,16 \%)$ apresentou significância, sendo vinte uma positivas e três negativas (ver TAB. 4.8).

A explicação dada anteriormente para a baixa associação entre a propaganda do candidato petista e a cobertura dos telejornais, quando considero todos os assuntos sem levar em conta intervalos temporais, também é válida aqui. Isto é, a diferença das prioridades das agendas ocorreu devido a um choque entre a estratégia da propaganda de Lula - que enfatizou mais os assuntos substantivos, esperança, pátria e mudança - com os critérios de noticiabilidade adotados pelos jornalistas na cobertura, que priorizaram os assuntos como agenda da campanha dos candidatos, estratégias, táticas e ataques.

TABELA 4.8 - 24 correlações para a verificação da transferência das prioridades de todos os assuntos da propaganda de Lula para a agenda de todos os assuntos da cobertura eleitoral de Lula nos telejornais (Jornal Nacional e Jornal da Record) $-1^{\circ}$. e $2^{\circ}$. turnos da eleição presidencial de 2002

\begin{tabular}{|c|c|c|c|c|}
\hline \multirow[t]{2}{*}{ Correlações } & \multicolumn{2}{|c|}{ Intervalos temporais de dias (time-lag) } & \multicolumn{2}{|l|}{ Coeficiente } \\
\hline & Dias Propaganda Lula & Dias Cobertura Lula & r spearman & significância \\
\hline 1 & $20 / 08,22 / 08$ e $24 / 08$ & $21 / 08,22 / 08,23 / 08,24 / 08,26 / 08$ e $27 / 08$ & 0,33 & \\
\hline 2 & $22 / 08,24 / 08$ e $27 / 08$ & $23 / 08,24 / 08,26 / 08,27 / 08,28 / 08$ e 29/08 & 0,15 & \\
\hline 3 & $24 / 08,27 / 08$ e $29 / 08$ & $26 / 08,27 / 08,28 / 08,29 / 08,30 / 08$ e $31 / 08$ & 0,42 & 0,05 \\
\hline 4 & $27 / 08,29 / 08$ e $31 / 08$ & $28 / 08,29 / 08,30 / 08,31 / 08,02 / 09$, e 03/09 & 0,34 & \\
\hline 5 & 29/08, 31/08 e 03/09 & $30 / 08,31 / 08,02 / 09,03 / 09,04 / 09$ e 05/09 & 0,02 & \\
\hline 6 & $31 / 08,03 / 08$ e 05/09 & $02 / 09,03 / 09,04 / 09,05 / 09,06 / 09$ e 07/09 & 0,13 & \\
\hline 7 & 03/09, 05/09 e 07/09 & 04/09, 05/09, $06 / 09,07 / 09,09 / 09$ e 10/09 & 0,11 & \\
\hline 8 & 05/09, 07/09 e 10/09 & $06 / 09,07 / 09,09 / 09,10 / 09,11 / 09$ e $12 / 09$ & $-0,17$ & \\
\hline 9 & $07 / 09,10 / 09$ e $12 / 09$ & $09 / 09,10 / 09,11 / 09,12 / 09,13 / 09$ e $14 / 09$ & 0,26 & \\
\hline 10 & $10 / 09,12 / 09$ e $14 / 09$ & $11 / 09,12 / 09,13 / 09,14 / 09,16 / 09$ e $17 / 09$ & 0,32 & \\
\hline 11 & $12 / 09,14 / 09$ e $17 / 09$ & $13 / 09,14 / 09,16 / 09,17 / 09,18 / 09$ e $19 / 09$ & 0,05 & \\
\hline 12 & $14 / 09,17 / 09$ e $19 / 09$ & $16 / 09,17 / 09,18 / 09,19 / 09,20 / 09$ e 21/09 & $-0,06$ & \\
\hline 13 & $17 / 09,19 / 09$ e $21 / 09$ & $18 / 09,19 / 09,20 / 09,21 / 09,23 / 09$ e 24/09 & $-0,25$ & \\
\hline 14 & $19 / 09,21 / 09$ e $24 / 09$ & $20 / 09,21 / 09,23 / 09,24 / 09,25 / 09$ e 26/09 & 0,18 & \\
\hline 15 & $21 / 09,24 / 09$ e $26 / 09$ & $23 / 09,24 / 09,25 / 09,26 / 09,27 / 09$ e $28 / 09$ & 0,27 & \\
\hline 16 & $24 / 09,26 / 09$ e $28 / 09$ & $25 / 09,26 / 09,27 / 09,28 / 09,30 / 09$ e 01/10 & 0,21 & \\
\hline 17 & $26 / 09,28 / 09$ e $01 / 10$ & $27 / 09,28 / 09,29 / 09,30 / 09,01 / 10$ e 02/10 & 0,04 & \\
\hline 18 & $28 / 09,01 / 10$ e $03 / 10$ & $29 / 09,30 / 09,01 / 10,02 / 10,03 / 10$ e 04/10 & 0,25 & \\
\hline 19 & $14 / 10,15 / 10$ e $16 / 10$ & $15 / 10,16 / 10,17 / 10,18 / 10,19 / 10$ e $21 / 10$ & 0,18 & \\
\hline 20 & $15 / / 10,16 / / 10$ e $17 / 10$ & $16 / 10,17 / 10,18 / 10,19 / 10,21 / 10$ e $22 / 10$ & 0,05 & \\
\hline 21 & $16 / 10,17 / 10$ e $18 / 10$ & $17 / 10,18 / 10,19 / 10,21 / 10,22 / 10$ e $23 / 10$ & 0,29 & \\
\hline 22 & $17 / 10,18 / 10$ e $19 / 10$ & $18 / 10,19 / 10,21 / 10,22 / 10,23 / 10$ e $24 / 10$ & 0,24 & \\
\hline 23 & $18 / 10,19 / 10$ e $21 / 10$ & $19 / 10,21 / 10,22 / 10,23 / 10,24 / 10$ e $25 / 10$ & 0,16 & \\
\hline 24 & $19 / 10,21 / 10$ e $22 / 10$ & $21 / 10,22 / 10,23 / 10,24 / 10,25 / 10$ e $26 / 10$ & 0,16 & \\
\hline
\end{tabular}


Já a hipótese de influência da agenda do candidato do PT na agenda dos noticiários é confirmada quando considero apenas os assuntos substantivos, uma vez que uma maioria de $70 \%$ das correlações teve significância, nenhuma correlação teve valor negativo e a média das associações foi de $+0,46$ (ver TAB. 4.9). Ou seja, pode-se afirmar portanto que as prioridades dos assuntos da agenda mais propositiva de Lula, apresentada na televisão, foram refletidas na agenda dos assuntos substantivos divulgados nos noticiários, de maneira que os telejornais não elaboraram uma ordem própria de questões independente da agenda do candidato petista.

TABELA 4.9 - 20 correlações para a verificação da transferência das prioridades dos assuntos substantivos da propaganda de Lula para a agenda dos assuntos substantivos da agenda da cobertura eleitoral de Lula nos telejornais (Jornal Nacional e Jornal da Record) $1^{\circ}$. e $2^{\circ}$. turnos da eleição presidencial de 2002 


\begin{tabular}{|c|c|c|c|c|}
\hline & \multicolumn{2}{|c|}{ Intervalos temporais de dias (time-lag) } & \multicolumn{2}{|l|}{ coeficiente } \\
\hline Correlações & Dias Propaganda Lula & Dias Cobertura Lula & r spearman & significância \\
\hline 1 & $20,22,24,27,29 / 08$ & $21,22,23,24,26,27,28,29,30,31 / 08$ & 0,7 & 0,05 \\
\hline 2 & $22,24,27,29$ e $31 / 08$ & $23,24,26,27,28,29,30,31 / 08,02$ e $03 / 09$ & 0,6 & 0,05 \\
\hline 3 & $24,27,29,31 / 08,03$ e $05 / 09$ & $26,27,28,29,30,31 / 08,02,03,04,05 / 09$ & 0,65 & 0,05 \\
\hline 4 & 27,29 e 31/08, 03 e 05/09 & $28,29,30,31 / 08,02,03,04,05,06,07 / 09$ & 0,44 & 0,05 \\
\hline 5 & 29 e $31 / 08,03,05,07 / 09$ & $30,31 / 08,02,03,04,05,06,07,09,10 / 09$ & 0,06 & \\
\hline 6 & $31 / 08,03,05,07,10 / 09$ & $02,03,04,05,06,07,09,10,11$ e $12 / 09$ & 0,11 & \\
\hline 7 & $03,05,07,10,12 / 09$ & $04,05,06,07,09,10,11,12,13$ e $14 / 09$ & 0,52 & 0,05 \\
\hline 8 & $05,07,10,12,14 / 09$ & $06,07,09,10,11,12,13,14,16$ e $17 / 09$ & 0,44 & 0,05 \\
\hline 9 & $07,10,12,14,17 / 09$ & $09,10,11,12,13,14,16,17,18$ e $19 / 09$ & 0,25 & \\
\hline 10 & $10,12,14,17,19 / 09$ & $11,12,13,14,16,17,18,19,20$ e $21 / 09$ & 0,44 & 0,05 \\
\hline 11 & $12,14,17,19,21 / 09$ & $13,14,16,17,18,19,20,21,23$ e $24 / 09$ & 0,25 & \\
\hline 12 & $14,17,19,21,24 / 09$ & $16,17,18,19,20,21,23,24$ e $25,26 / 09$ & 0,61 & 0,05 \\
\hline 13 & $17,19,21,24,26 / 09$ & $18,19,20,21,23,24,25,26,27$ e $28 / 09$ & 0,55 & 0,05 \\
\hline 14 & $19,21,24,26,28 / 09$ & $20,21,23,24,25,26,27,28,30 / 09$ e $01 / 10$ & 0,65 & 0,05 \\
\hline 15 & $21,24,26,28 / 09$ e $01 / 10$ & $23,24,25,26,27,28,30 / 09,01,03 / 10$ & 0,47 & 0,05 \\
\hline 16 & $24,26,28,01,02 / 10$ & $25,26,27,28,30 / 09,01,03 / 10$ & 0,28 & \\
\hline 17 & $14,15,16,17,18 / 10$ & $15,16,17,18,19,21,22,23,24$ e $25 / 10$ & 0,28 & \\
\hline 18 & $15,16,17,18,19 / 10$ & $16,17,18,19,21,22,23,24,25$ e $26 / 10$ & 0,56 & 0,05 \\
\hline 19 & $17,18,19,20,21 / 10$ & $18,19,21,22,23,24,25$ e $26 / 10$ & 0,67 & 0,05 \\
\hline 20 & $18,19,20,21,22 / 10$ & $19,21,22,23,24,25$ e $26 / 10$ & 0,76 & 0,01 \\
\hline
\end{tabular}

De acordo ainda com a TAB. 4.9, observa-se que a maior articulação entre a agenda da propaganda de televisão e a cobertura dos noticiários ocorreu em três intervalos distintos: o primeiro, no início da campanha na tevê, entre o período de 20 de agosto a 7 de setembro; o segundo, na parte final da campanha do primeiro turno, entre 14 de setembro a 1 de outubro; e o último período de coordenação entre as duas agendas referiu-se ao segundo turno quase que de modo integral, entre 15 a 26 de outubro de 2002.

No primeiro período, a discussão feita no horário eleitoral de Lula do dia 20 de agosto, sobre a construção da plataforma da Petrobrás em Cingapura e o desemprego no Brasil, foi debatida no Jornal da Record, nos dias 21 e 23 de agosto. Neste telejornal ressaltou-se a crítica de Lula ao governo pela admissão da construção da plataforma da empresa brasileira no exterior. O mesmo noticiário também deu espaço para a Petrobrás se defender dos ataques da propaganda petista na televisão.

Outro tema levantado na propaganda de Luiz Inácio Lula da Silva na tevê, que se deslocou para a cobertura dos telejornais, foi em relação à Embraer. Lula conseguiu, tanto no Jornal Nacional como no Jornal da Record, repercutir o que havia divulgado no horário eleitoral de televisão a respeito da necessidade do fortalecimento do setor aéreo no país. O candidato também 
obteve êxito em veicular nos telejornais suas críticas ao governo com referência à abertura de concorrências para empresas estrangeiras produzirem os aviões militares para a Força Aérea Brasileira (FAB). Lula manifestou ser contrário às encomendas das aeronaves por empresas internacionais, defendendo a necessidade da construção destes aviões no país, já que isso poderia gerar a transferência da tecnologia e, conseqüentemente, maior soberania para o Brasil.

Se o Brasil não tiver uma indústria aérea forte, sadia, saudável do ponto de vista econômico, o nosso transporte interno, o que vai acontecer? Essas empresas vão quebrar e a gente vai ter empresas estrangeiras ocupando o nosso espaço aéreo, o nosso transporte interno, e isso, obviamente, não é bom para a nossa soberania.

No segundo período, houve uma grande discussão sobre a questão da segurança na propaganda de televisão. Várias propostas para esta área foram veiculadas, como a redução da pobreza, distribuição de renda, criação de empregos e de programas culturais para os jovens das periferias das grandes cidades. Esta mesma questão foi repercutida no Jornal Nacional. Dentre outras ocasiões em que esta temática veio à tona na cobertura, foi na entrevista com Lula que a criminalidade e violência foram bastante enfatizadas:

Bonner - Vamos falar do seu programa de governo em relação à violência. Num dos programas que aparece na televisão fica claro a ligação entre a violência e a falta de ações sociais e a pobreza. Num dos filmes, um rapaz desempregado vai para a rua e comete um assalto. Como o senhor acha que um pobre, passando pela mesma situação, pode receber uma mensagem assim?

Lula - O que nós quisemos foi chocar a opinião pública, para as pessoas perceberem que a ausência de políticas públicas nos lugares mais pobres da periferia desse país induz o jovem à violência. Nós fizemos um estudo, através da Universidade Federal de Minas Gerais, e ficou constatado que a maioria da delinqüência juvenil acontece exatamente nos bairros periféricos, onde não tem creches, área de lazer, escola e emprego. E acontece 
exatamente às $6^{\text {as }}$ e sábados, das 22 às 3 horas. Por isso que nós fazemos a ligação direta da ausência do Estado, do poder público, com políticas para motivar o jovem a não cair na "bandidagem". Mas nós temos muito investimento no $1^{\circ}$. emprego, educação, cultura, lazer e esporte como forma de bem utilizar o tempo da nossa juventude para tirá-la do caminho da criminalidade.

A questão da fome, discutida no horário eleitoral do PT, também foi explorada na agenda da cobertura, principalmente no telejornal da Record, na ocasião em que Lula prometeu, caso vencesse a eleição, viajar com todos seus futuros ministros pelo país, "para ver a fome de perto".

Em relação ao assunto educação, a proposta do candidato petista de melhora do ensino público e da redução da evasão escolar, divulgada no horário eleitoral, foi difundida nos telejornais, através de relatos dos jornalistas sobre palestras e lançamento de projetos para a área da educação feitos pela candidatura Lula.

Nesse período também os telejornais se tornaram um bom veículo para Luiz Inácio Lula da Silva e outras lideranças do PT, como por exemplo o deputado federal Aloízio Mercadante, repisar os compromissos com o FMI, lembrados constantemente no horário eleitoral e spots pelo candidato petista: "O PT tem deixado claro suas posições públicas, formalizado por escrito. Lula lançou uma carta aos brasileiros, assumindo compromissos de honrar os contratos internacionais, de manter o superávit primário, de manter a estabilidade econômica".

No terceiro período, referente ao segundo turno da eleição presidencial, os assuntos econômicos discutidos na propaganda de tevê e em especial no horário eleitoral, foram freqüentemente colocados pelos jornalistas na pauta dos noticiários. Lula conseguiu fazer suas críticas ao governo nos telejornais, principalmente na entrevista que concedeu ao telejornal global:

Agora o governo sabe que eu tenho razão nas críticas que eu fiz, porque o povo assiste ao Jornal Nacional todo dia, vendo vocês afirmarem que o dólar 
sobe, que a bolsa cai todo santo dia. Como quem é governo é o presidente Fernando Henrique Cardoso, ele precisa assumir o ônus de uma política econômica equivocada, porque não acreditou na produção industrial, não acreditou na produção agrícola, que é a mais produtiva e a mais competitiva do mundo. É por isso que o Brasil, um país enorme, está dependendo de dinheiro emprestado, o que é um absurdo.

Lula também teve sucesso em manifestar na cobertura dos telejornais suas promessas de retomada do crescimento econômico e de geração de empregos. Mas o assunto sobre o compromisso dos contratos e controle da inflação, frisado persistentemente no final do primeiro turno da eleição, tornouse o tópico mais importante das notícias do Jornal Nacional e Jornal da Record, como ilustra esta declaração de Lula veiculada pelo noticiário da Record: "Vamos conduzir a política cambial, de modo que a necessária flutuação da moeda não ocorra com os excessos atuais, manter o controle da inflação, assegurar o superávit primário suficiente para que se inverta o quadro do atual governo".

Dando continuidade à análise das relações entre estes dois veículos, testei a hipótese incluindo nas correlações unicamente os assuntos restantes. Os achados apontam uma baixa coordenação entre a agenda do candidato e dos noticiários, o que, por conseqüência, leva à rejeição da hipótese de que Lula conseguiu transpor para a cobertura a hierarquia dos assuntos restantes de sua propaganda: das vinte associações realizadas, nenhuma teve significância; 12 foram positivas e oito negativas, como podemos visualizar na TAB. 4.10. 
TABELA 4.10 - 20 correlações para a verificação da transferência das prioridades dos assuntos restantes da propaganda de Lula para a agenda dos assuntos restantes da cobertura eleitoral de Lula nos telejornais (Jornal Nacional e Jornal da Record) $1^{\circ}$. e $2^{\circ}$. turnos da eleição presidencial de 2002

\begin{tabular}{|c|c|c|c|c|}
\hline & \multicolumn{2}{|c|}{ Intervalos temporais de dias (time-lag) } & \multicolumn{2}{|l|}{ coeficiente } \\
\hline Correlações & Dias Propaganda Lula & Dias Cobertura Lula & r spearman & significância \\
\hline 1 & $20,22,24,27,29 / 08$ & $21,22,23,24,26,27,28,29,30,31 / 08$ & 0,16 & \\
\hline 2 & $22,24,27,29$ e $31 / 08$ & $23,24,26,27,28,29,30,31 / 08,02$ e $03 / 09$ & 0,2 & \\
\hline 3 & $24,27,29,31 / 08,03$ e $05 / 09$ & $26,27,28,29,30,31 / 08,02,03,04,05 / 09$ & 0,12 & \\
\hline 4 & 27,29 e $31 / 08,03$ e $05 / 09$ & $28,29,30,31 / 08,02,03,04,05,06,07 / 09$ & $-0,12$ & \\
\hline 5 & 29 e $31 / 08,03,05,07 / 09$ & $30,31 / 08,02,03,04,05,06,07,09$ e $10 / 09$ & $-0,88$ & \\
\hline 6 & $31 / 08,03,05,07,10 / 09$ & $02,03,04,05,06,07,09,10,11$ e $12 / 09$ & $-0,06$ & \\
\hline 7 & $03,05,07,10,12 / 09$ & $04,05,06,07,09,10,11,12,13$ e $14 / 09$ & $-0,5$ & \\
\hline 8 & $05,07,10,12,14 / 09$ & $06,07,09,10,11,12,13,14,16$ e $17 / 09$ & $-0,44$ & \\
\hline 9 & $07,10,12,14,17 / 09$ & $09,10,11,12,13,14,16,17,18$ e $19 / 09$ & $-0,52$ & \\
\hline 10 & $10,12,14,17,19 / 09$ & $11,12,13,14,16,17,18,19,20$ e $21 / 09$ & 0,22 & \\
\hline 11 & $12,14,17,19,21 / 09$ & $13,14,16,17,18,19,20,21,23$ e $24 / 09$ & $-0,13$ & \\
\hline 12 & $14,17,19,21,24 / 09$ & $16,17,18,19,20,21,23,24$ e $25,26 / 09$ & 0,02 & \\
\hline 13 & $17,19,21,24,26 / 09$ & $18,19,20,21,23,24,25,26,27$ e $28 / 09$ & 0,03 & \\
\hline 14 & $19,21,24,26,28 / 09$ & $20,21,23,24,25,26,27,28,30 / 09$ e $01 / 10$ & 0,12 & \\
\hline 15 & $21,24,26,28 / 09$ e $01 / 10$ & $23,24,25,26,27,28,30 / 09,01,03 / 10$ & 0,23 & \\
\hline 16 & $24,26,28,01,02 / 10$ & $25,26,27,28,30 / 09,01,03 / 10$ & $-0,03$ & \\
\hline 17 & $14,15,16,17,18 / 10$ & $15,16,17,18,19,21,22,23,24$ e $25 / 10$ & 0,06 & \\
\hline 18 & $15,16,17,18,19 / 10$ & $16,17,18,19,21,22,23,24,25$ e $26 / 10$ & 0,07 & \\
\hline 19 & $17,18,19,20,21 / 10$ & $18,19,21,22,23,24,25$ e $26 / 10$ & 0,07 & \\
\hline 20 & $18,19,20,21,22 / 10$ & $19,21,22,23,24,25$ e $26 / 10$ & 0,14 & \\
\hline
\end{tabular}

Esse resultado pode ser explicado pela "metáfora da cebola" (ver QUADRO 1.4, p.17). A camada mais próxima da agenda da cobertura dos telejornais é composta pelos valores dos jornalistas. Nela, os critérios de noticiabilidade filtram os assuntos a serem considerados na cobertura. Como já ressaltei anteriormente, na literatura internacional, os assuntos com maior valor de noticiabilidade para a mídia numa cobertura eleitoral são os ataques entre os candidatos, pesquisas eleitorais, agenda de campanha e questões sobre estratégias. Por conseguinte, sendo a agenda dos assuntos restantes da propaganda de tevê do candidato petista muito pouco baseada em assuntos de alto valor de noticiabilidade, é compreensível que a agenda da propaganda petista não tenha influenciado os assuntos restantes da agenda dos telejornais, 
posto que a segunda assinalou mais os assuntos que a primeira sublinhou menos e vice-versa. Lula não teve êxito em transferir para a agenda dos telejornais os assuntos que manifestavam apelos de esperança, de patriotismo e de mudança, bastante explorados em seu horário eleitoral de televisão, uma vez que os noticiários volveram suas prioridades aos assuntos da agenda da campanha do candidato, conflitos e estratégias.

De modo geral, não houve correspondência entre a hierarquia da pauta da propaganda de Lula, de um determinado período, e a ordem dos assuntos da cobertura desta candidatura num período posterior. A despeito da não correspondência, quando considerei apenas os assuntos substantivos, a hipótese de associação entre a pauta da propaganda e do conteúdo dos noticiários foi aceita, o que nos permite dizer que Lula conseguiu fazer com que os telejornais elaborassem suas pautas levando em conta as prioridades dos assuntos substantivos da agenda veiculada na propaganda. Essa influência só foi detectada no conjunto de correlações entre os assuntos substantivos, e não quando considerei os assuntos restantes nas correlações.

É importante ressaltar também que, além de ter tido sucesso em estabelecer a ordem da pauta substantiva dos telejornais, o candidato do PT conseguiu ainda deslocar para a cobertura dos noticiários muitas de suas propostas de programa de governo, divulgadas extensamente no horário eleitoral, como, por exemplo, a promessa de geração de empregos e de crescimento econômico, bem como seu comprometimento com uma mudança "confiável" e "responsável" da política econômica do país.

\section{Influência da cobertura do noticiário de Lula na propaganda de Lula}

A hipótese de que há influência do noticiário sobre a propaganda de Lula, de acordo com intervalos temporais definidos e considerando todos os assuntos das agendas, é rejeitada: das 24 correlações realizadas, nenhuma apresentou significância, sendo vinte e uma positivas e três negativas (ver TAB. 4.11). 
A explicação para a refutação da conjetura é a mesma atribuída anteriormente à rejeição da hipótese de influência da propaganda de Lula na cobertura de Lula nos telejornais. Ou seja, diariamente os noticiários deram maior destaque aos assuntos sobre a campanha, estratégias, ataques e pesquisas, enquanto na propaganda de televisão, de maneira oposta, a discussão de propostas, apelos de esperança, mudança e de pátria foram mais frisados. Dessa maneira, a cobertura não conseguiu enviar para a agenda da propaganda de Lula suas saliências.

TABELA 4.11 - 24 correlações para a verificação da transferência das prioridades de todos assuntos da cobertura eleitoral de Lula nos telejornais (Jornal Nacional e Jornal da Record) para a agenda de todos os assuntos da propaganda de Lula na tevê $-1^{\circ}$. e $2^{\circ}$. turnos da eleição presidencial de 2002

\begin{tabular}{|c|c|c|c|c|}
\hline & \multicolumn{2}{|c|}{ Intervalos temporais de dias (time-lag) } & \multicolumn{2}{|l|}{ Coeficiente } \\
\hline Correlações & Dias Cobertura Lula & Dias Propaganda Lula & r spearman & significância \\
\hline 1 & $12,13,14,15,16$ e $17 / 08$ & 20,22 e $24 / 08$ & 0,22 & \\
\hline 2 & $15,16,17,19,20$ e $21 / 08$ & 22,24 e $27 / 08$ & 0,11 & \\
\hline 3 & $17,19,20,21,22$ e $23 / 08$ & 24,27 e $29 / 08$ & 0,17 & \\
\hline 4 & $20,21,22$ e 23,24 e $26 / 08$ & 27,29 e $31 / 08$ & 0,35 & \\
\hline 5 & $22,23,24,26,27$ e $28 / 08$ & $29,31 / 08$ e $03 / 09$ & 0,26 & \\
\hline 6 & $23,24,26,27,28,29 / 08$ & $31 / 08,03$ e 05/09 & 0,11 & \\
\hline 7 & $27,28,29,30,31 / 08$ e $02 / 09$ & 03,05 e $07 / 09$ & 0,14 & \\
\hline 8 & $29,30,31 / 08$ e 02,03 e $04 / 09$ & 05,07 e $10 / 09$ & $-0,25$ & \\
\hline 9 & $31 / 08,02,03,04,05$ e 06/09 & $07,10,12 / 09$ & 0,1 & \\
\hline 10 & $03,04,05,06,07$ e 09/09 & 10,12 e $14 / 09$ & 0,19 & \\
\hline 11 & $05,06,07,09,10$ e $11 / 09$ & 12,14 e $17 / 09$ & $-0,01$ & \\
\hline 12 & $07,09,10,11,12,13 / 09$ & 14,17 e $19 / 09$ & 0,09 & \\
\hline 13 & $10,11,12,13,14,16 / 09$ & 17,19 e $21 / 09$ & 0,07 & \\
\hline 14 & $12,13,14,16,17$ e $18 / 09$ & 19,21 e $24 / 09$ & $-0,13$ & \\
\hline 15 & $14,16,17,18,19$ e $20 / 09$ & 21,24 e $26 / 09$ & 0,21 & \\
\hline 16 & $17,18,19,20,21$ e $23 / 09$ & 24,26 e $28 / 09$ & 0,26 & \\
\hline 17 & $19,20,21,23,24$ e $25 / 09$ & $26,28 / 09$ e $01 / 10$ & 0,25 & \\
\hline 18 & $21,23,24,25,26,27 / 09$ & $28 / 09,01$ e $03 / 10$ & 0,19 & \\
\hline 19 & $7,8,9,10,11$ e $12 / 10$ & 14,15 e $16 / 10$ & 0,12 & \\
\hline 20 & $8,9,10,11,12$ e $14 / 10$ & 15,16 e $17 / 10$ & 0,22 & \\
\hline 21 & $9,10,11,12,14,15 / 10$ & 16,17 e $18 / 10$ & 0,2 & \\
\hline 22 & $10,11,12,14,15$ e $16 / 10$ & 17,18 e $19 / 10$ & 0,17 & \\
\hline 23 & $11,12,14,15,16$ e $17 / 10$ & 18,19 e $21 / 10$ & 0,26 & \\
\hline 24 & $12,14,15,16,17$ e $18 / 10$ & 19,21 e $22 / 10$ & 0,45 & \\
\hline
\end{tabular}

Quanto à hipótese da transferência da hierarquia dos assuntos substantivos da cobertura eleitoral dos telejornais para a agenda do candidato 
Lula, tampouco se comprovou, uma vez que somente $20 \%$ das correlações têm significância, e a média de todas associações é de +0,38 (ver TAB. 4.12).

Este resultado indica que não houve influência da cobertura de Lula realizada pelos jornalistas dos noticiários, na propaganda do candidato, nem quando tomados somente os assuntos substantivos. As ordens dos assuntos dos telejornais não foram reproduzidas na agenda da propaganda de televisão nos intervalos temporais estabelecidos.

TABELA 4.12 - 20 correlações para a verificação da transferência das prioridades dos assuntos substantivos da cobertura de Lula nos telejornais (Jornal Nacional e Jornal da Record) para a agenda dos assuntos substantivos da propaganda eleitoral de Lula $1^{\circ}$. e $2^{\circ}$. turnos da eleição presidencial de 2002

\begin{tabular}{|c|c|c|c|c|}
\hline & \multicolumn{2}{|c|}{ Intervalos temporais de dias (time-lag) } & \multicolumn{2}{|l|}{ Coeficiente } \\
\hline Correlações & Dias Cobertura Lula & Dias Propaganda Lula & r spearman & significância \\
\hline 1 & $8,9,10,12,13,14,15,16,17,18 / 08$ & $20,22,24,27$ e $29 / 08$ & 0,34 & \\
\hline 2 & $10,12,13,14,15,16,17,19,20$ e $23 / 08$ & $22,24,27,29$ e $31 / 08$ & 0,22 & \\
\hline 3 & $13,14,15,16,17,19,20,21,22$ e $23 / 08$ & $24,27,29,31 / 08$ e $03 / 09$ & 0,1 & \\
\hline 4 & $15,16,17,19,20,21,22,23,24,27 / 08$ & $27,29,31 / 08,03$ e $05 / 09$ & 0,23 & \\
\hline 5 & $17,19,20,21,22,23,24,27,28$ e $29 / 08$ & $29,31 / 08,03,05,07 / 09$ & 0,42 & \\
\hline 6 & $20,21,22,23,24,26,27,28,29$ e $30 / 08$ & $31 / 08,03,05,07$ e $10 / 09$ & 0,62 & 0,05 \\
\hline 7 & $22,23,24,26,27,28,29,30,31 / 08$ e $02 / 09$ & $03,05,07,10$ e $12 / 09$ & 0,41 & \\
\hline 8 & $24,26,27,28,29,30,31,02,03$ e $04 / 09$ & $05,07,10,12$ e $14 / 09$ & 0,33 & \\
\hline 9 & $27,28,29,30,31,02,03,04,05$ e $06 / 09$ & $07,10,12,14$ e $17 / 09$ & 0,28 & \\
\hline 10 & $29,30,31,02,03,04,05,06,07$ e 09/09 & $10,12,14,17$ e $19 / 09$ & 0,51 & \\
\hline 11 & $31,02,03,04,05,06,07,09,10$ e $11 / 09$ & $12,14,17,19$ e $21 / 09$ & 0,29 & \\
\hline 12 & $03,04,05,06,07,09,10,11,12$ e $13 / 09$ & $14,17,19,21$ e $24 / 09$ & 0,65 & 0,01 \\
\hline 13 & $05,06,07,09,10,11,12,13,14$ e $16 / 09$ & $17,19,21,24$ e $26 / 09$ & 0,45 & \\
\hline 14 & $07,09,10,11,12,13,14,16,17$ e $18 / 09$ & $19,21,24,26$ e $28 / 09$ & 0,17 & \\
\hline 15 & $10,11,12,13,14,16,17,18,19$ e $20 / 09$ & $21,24,26,28 / 09$ e $01 / 10$ & 0,39 & \\
\hline 16 & $01,02,03,04,05,07,09,10,11$ e $12 / 10$ & $14,15,16,17$ e $18 / 10$ & 0,34 & \\
\hline 17 & $02,03,04,05,07,09,10,11,12$ e $14 / 10$ & $15,16,17,18$ e $19 / 10$ & 0,55 & 0,05 \\
\hline 18 & $03,04,05,07,09,10,11,12,14$ e $15 / 10$ & $16,17,18,19$ e $21 / 10$ & 0,31 & \\
\hline 19 & $04,05,07,09,10,11,12,14,15$ e $16 / 10$ & $17,18,19,21$ e $22 / 10$ & 0,43 & \\
\hline 20 & $05,07,09,10,11,12,14,15,16$ e $17 / 10$ & $18,19,21,22$ e $23 / 10$ & 0,56 & 0,05 \\
\hline
\end{tabular}

\section{Influência da propaganda de Serra na cobertura eleitoral de Serra}

De modo distinto do caso de Lula, a hipótese da transferência da hierarquia dos assuntos discutidos pela agenda de Serra para a agenda da cobertura dos telejornais sobre o candidato tucano foi aceita, quando considerei todos os assuntos: 54,16\% das correlações foram significantes, vinte e três positivas e somente uma negativa (ver TAB. 4.13). 
A existência de homogeneidade das ordens dos assuntos, ou correspondência entre elas, pode ser explicada pelo mesmo motivo já explicitado no tópico anterior, quando testamos a associação entre todos os assuntos dessas duas agendas, sem levar em conta intervalos temporais (timelags). Ou melhor dizendo, a propaganda tucana discutiu menos assuntos substantivos $(59,34 \%)$ do que a propaganda de Lula $(71,56 \%)$, havendo um espaço significativo para os assuntos restantes (33,96\%), principalmente para aqueles baseados em ataques, que, de acordo com os critérios de noticiabilidade dos jornalistas, apresentam um alto valor noticioso.

TABELA 4.13 - 24 correlações para a verificação da transferência das prioridades de todos os assuntos da propaganda de Serra para a agenda de todos os assuntos da cobertura eleitoral de Serra nos telejornais (Jornal Nacional e Jornal da Record) $-1^{\circ}$. e $2^{\circ}$. turnos da eleição presidencial de 2002

\begin{tabular}{|c|c|c|c|c|}
\hline & \multicolumn{2}{|c|}{ Intervalos temporais de dias (time-lag) } & \multicolumn{2}{|l|}{ coeficiente } \\
\hline Correlações & Dias Propaganda Serra & Dias Cobertura Serra & r spearman & significância \\
\hline 1 & $20 / 08,22 / 08$ e $24 / 08$ & $21 / 08,22 / 08,23 / 08,24 / 08,26 / 08$ e $27 / 08$ & 0,24 & \\
\hline 2 & $22 / 08,24 / 08$ e $27 / 08$ & $23 / 08,24 / 08,26 / 08,27 / 08,28 / 08$ e $29 / 08$ & 0,65 & 0,05 \\
\hline 3 & $24 / 08,27 / 08$ e $29 / 08$ & $26 / 08,27 / 08,28 / 08,29 / 08,30 / 08$ e $31 / 08$ & 0,72 & 0,05 \\
\hline 4 & $27 / 08,29 / 08$ e $31 / 08$ & $28 / 08,29 / 08,30 / 08,31 / 08,02 / 09$, e $03 / 09$ & 0,77 & 0,01 \\
\hline 5 & $29 / 08,31 / 08$ e $03 / 09$ & $30 / 08,31 / 08,02 / 09,03 / 09,04 / 09$ e $05 / 09$ & 0,2 & \\
\hline 6 & $31 / 08,03 / 08$ e $05 / 09$ & 02/09, 03/09, 04/09, 05/09, 06/09 e 07/09 & 0,06 & \\
\hline 7 & $03 / 09,05 / 09$ e $07 / 09$ & $04 / 09,05 / 09,06 / 09,07 / 09,09 / 09$ e $10 / 09$ & 0,05 & \\
\hline 8 & 05/09, 07/09 e 10/09 & $06 / 09,07 / 09,09 / 09,10 / 09,11 / 09$ e $12 / 09$ & 0,06 & \\
\hline 9 & $07 / 09,10 / 09$ e $12 / 09$ & 09/09, 10/09, 11/09, 12/09, 13/09 e 14/09 & $-0,15$ & \\
\hline 10 & $10 / 09,12 / 09$ e $14 / 09$ & $11 / 09,12 / 09,13 / 09,14 / 09,16 / 09$ e $17 / 09$ & 0,06 & \\
\hline 11 & $12 / 09,14 / 09$ e $17 / 09$ & $13 / 09,14 / 09,16 / 09,17 / 09,18 / 09$ e $19 / 09$ & 0,08 & \\
\hline 12 & $14 / 09,17 / 09$ e $19 / 09$ & $16 / 09,17 / 09,18 / 09,19 / 09,20 / 09$ e $21 / 09$ & 0,45 & 0,05 \\
\hline 13 & $17 / 09,19 / 09$ e $21 / 09$ & $18 / 09,19 / 09,20 / 09,21 / 09,23 / 09$ e $24 / 09$ & 0,68 & 0,05 \\
\hline 14 & $19 / 09,21 / 09$ e $24 / 09$ & $20 / 09,21 / 09,23 / 09,24 / 09,25 / 09$ e $26 / 09$ & 0,51 & 0,05 \\
\hline 15 & $21 / 09,24 / 09$ e $26 / 09$ & $23 / 09,24 / 09,25 / 09,26 / 09,27 / 09$ e $28 / 09$ & 0,34 & 0,05 \\
\hline 16 & $24 / 09,26 / 09$ e $28 / 09$ & $25 / 09,26 / 09,27 / 09,28 / 09,30 / 09$ e 01/10 & 0,06 & \\
\hline 17 & $26 / 09,28 / 09$ e $01 / 10$ & $27 / 09,28 / 09,29 / 09,30 / 09,01 / 10$ e $02 / 10$ & 0,08 & \\
\hline 18 & $28 / 09,01 / 10$ e $03 / 10$ & $29 / 09,30 / 09,01 / 10,02 / 10,03 / 10$ e $04 / 10$ & 0,19 & \\
\hline 19 & $14 / 10,15 / 10$ e $16 / 10$ & $15 / 10,16 / 10,17 / 10,18 / 10,19 / 10$ e $21 / 10$ & 0,61 & 0,05 \\
\hline 20 & $15 / / 10,16 / / 10$ e $17 / 10$ & $16 / 10,17 / 10,18 / 10,19 / 10,21 / 10$ e $22 / 10$ & 0,74 & 0,01 \\
\hline 21 & $16 / 10,17 / 10$ e $18 / 10$ & $17 / 10,18 / 10,19 / 10,21 / 10,22 / 10$ e $23 / 10$ & 0,65 & 0,01 \\
\hline 22 & $17 / 10,18 / 10$ e $19 / 10$ & $18 / 10,19 / 10,21 / 10,22 / 10,23 / 10$ e $24 / 10$ & 0,63 & 0,01 \\
\hline 23 & $18 / 10,19 / 10$ e $21 / 10$ & $19 / 10,21 / 10,22 / 10,23 / 10,24 / 10$ e $25 / 10$ & 0,74 & 0,01 \\
\hline 24 & $19 / 10,21 / 10$ e $22 / 10$ & $21 / 10,22 / 10,23 / 10,24 / 10,25 / 10$ e $26 / 10$ & 0,81 & 0,01 \\
\hline
\end{tabular}

Da mesma forma que no caso de Lula, a hipótese de influência da agenda de Serra na cobertura dos telejornais foi validada, quando avalio somente os assuntos substantivos, pois $75 \%$ das correlações são significantes 
e todas positivas, sendo a média das correlações de +0,55 (ver TAB. 4.14). Esses resultados permitem admitir que a ênfase da discussão dos assuntos substantivos da agenda de Serra, veiculada na propaganda de televisão, de acordo com os intervalos temporais estabelecidos, foi transferida para a pauta da agenda substantiva dos noticiários observados.

TABELA 4.14 - 20 correlações para a verificação da transferência das prioridades dos assuntos substantivos da propaganda de Serra para a agenda dos assuntos substantivos da agenda da cobertura eleitoral de Serra nos telejornais (Jornal Nacional e Jornal da Record) $1^{\circ}$. e $2^{\circ}$. turnos da eleição presidencial de 2002

\begin{tabular}{|c|c|c|c|c|}
\hline & \multicolumn{2}{|c|}{ Intervalos temporais de dias (time-lag) } & \multicolumn{2}{|l|}{ coeficiente } \\
\hline Correlações & Dias Propaganda Serra & Dias Cobertura Serra & r spearman & significância \\
\hline 1 & $20,22,24,27,29 / 08$ & $21,22,23,24,26,27,28,29,30,31 / 08$ & 0,45 & 0,05 \\
\hline 2 & $22,24,27,29$ e $31 / 08$ & $23,24,26,27,28,29,30,31 / 08,02$ e $03 / 09$ & 0,85 & 0,01 \\
\hline 3 & $24,27,29,31 / 08,03$ e $05 / 09$ & $26,27,28,29,30,31 / 08,02,03,04,05 / 09$ & 0,84 & 0,05 \\
\hline 4 & 27,29 e $31 / 08,03$ e $05 / 09$ & $28,29,30,31 / 08,02,03,04,05,06,07 / 09$ & 0,7 & 0,05 \\
\hline 5 & 29 e $31 / 08,03,05,07 / 09$ & $30,31 / 08,02,03,04,05,06,07,09,10 / 09$ & 0,37 & \\
\hline 6 & $31 / 08,03,05,07,10 / 09$ & $02,03,04,05,06,07,09,10,11$ e $12 / 09$ & 0,55 & 0,05 \\
\hline 7 & $03,05,07,10,12 / 09$ & $04,05,06,07,09,10,11,12,13$ e $14 / 09$ & 0,33 & \\
\hline 8 & $05,07,10,12,14 / 09$ & $06,07,09,10,11,12,13,14,16$ e $17 / 09$ & 0,1 & \\
\hline 9 & $07,10,12,14,17 / 09$ & $09,10,11,12,13,14,16,17,18$ e $19 / 09$ & 0,28 & \\
\hline 10 & $10,12,14,17,19 / 09$ & $11,12,13,14,16,17,18,19,20$ e $21 / 09$ & 0,51 & 0,05 \\
\hline 11 & $12,14,17,19,21 / 09$ & $13,14,16,17,18,19,20,21,23$ e $24 / 09$ & 0,45 & 0,05 \\
\hline 12 & $14,17,19,21,24 / 09$ & $16,17,18,19,20,21,23,24$ e $25,26 / 09$ & 0,65 & 0,05 \\
\hline 13 & $17,19,21,24,26 / 09$ & $18,19,20,21,23,24,25,26,27$ e $28 / 09$ & 0,85 & 0,01 \\
\hline 14 & $19,21,24,26,28 / 09$ & $20,21,23,24,25,26,27,28,30 / 09$ e $01 / 10$ & 0,67 & 0,05 \\
\hline 15 & $21,24,26,28 / 09$ e $01 / 10$ & $23,24,25,26,27,28,30 / 09,01,03 / 10$ & 0,49 & 0,05 \\
\hline 16 & $24,26,28,01,02 / 10$ & $25,26,27,28,30 / 09,01,03 / 10$ & 0,34 & \\
\hline 17 & $14,15,16,17,18 / 10$ & $15,16,17,18,19,21,22,23,24$ e $25 / 10$ & 0,53 & 0,05 \\
\hline 18 & $15,16,17,18,19 / 10$ & $16,17,18,19,21,22,23,24,25$ e $26 / 10$ & 0,75 & 0,05 \\
\hline 19 & $17,18,19,20,21 / 10$ & $18,19,21,22,23,24,25$ e $26 / 10$ & 0,77 & 0,05 \\
\hline 20 & $18,19,20,21,22 / 10$ & $19,21,22,23,24,25$ e $26 / 10$ & 0,6 & 0,05 \\
\hline
\end{tabular}

Os períodos nos quais houve maior coordenação entre a agenda substantiva da propaganda e dos telejornais foram três. O primeiro ocorreu no 
início da campanha na tevê, entre 20 de agosto a 7 de setembro. O segundo durante o período final do primeiro turno. O terceiro período de correspondência entre a agenda da propaganda eleitoral de tevê e a cobertura dos telejornais ocorreu praticamente durante toda campanha do segundo turno da eleição.

No período inicial da campanha de Serra na propaganda de tevê (horário eleitoral e spots) houve uma ampla discussão sobre o programa de governo para as áreas da economia e segurança. Como já foi exposto no capítulo anterior, o emprego foi tomado como principal fonte de preocupação da plataforma do candidato tucano. O "Projeto $2^{a}$. feira" - que se caracterizava pela proposta de geração de 8 milhões de empregos, através do crescimento da economia e do investimento em setores que mais criam empregos, como agricultura, turismo, construção civil, educação e saúde, foi transferido para a cobertura eleitoral.

Nos noticiários de tevê, Serra teve a oportunidade de falar sobre suas propostas para a agropecuária: "É o que segura hoje a nossa balança de pagamentos, e o investimento neste setor vai gerar 3 milhões de empregos a mais"; da necessidade de criação de novas linhas de crédito: "É o crédito necessário para exportar aviões, para exportar produtos siderúrgicos, onde também somos campeões, exportar turismo, que é uma atividade muito subaproveitada no Brasil"; da reativação da Sudene e de um projeto para a melhora das rodovias federais: "Primeiro, terminar a ferrovia Norte-Sul, que é fundamental para Goiás, para escoar a produção no Brasil e terminar a duplicação da estrada Goiânia-Brasília".

A questão da segurança, fortemente explorada no horário eleitoral tucano, também ganhou destaque nos telejornais. Na cobertura, Serra teve a chance de falar sobre a mudança da legislação penal, quando foi visitar no hospital o compositor Paulo Negueba, do grupo "O Rappa", que estava se recuperando de dois tiros que havia recebido numa operação da Polícia Militar na favela de Vigário Geral, no Rio de Janeiro. Serra também conseguiu fazer repercutir no noticiário seus projetos para segurança pública, como a construção de presídios federais e punições mais severas aos criminosos, 
quando foi questionado sobre o que achava da utilização de celulares por bandidos de dentro da cadeia, como ocorreu no caso "Fernandinho Beira-Mar".

No segundo e no terceiro períodos, a questão da geração de empregos e propostas para a área da segurança permaneceu na propaganda eleitoral de Serra e também na cobertura do candidato tucano nos noticiários de televisão. As entrevistas com o candidato do PSDB no Jornal Nacional e Jornal da Record foram ótimas oportunidades para Serra debater seu "Projeto $2^{\mathrm{a}}$. feira" e discorrer acerca de seu programa para a segurança pública. Especificamente no Jornal da Record, Boris Casoy interpelou o candidato tucano sobre a viabilidade do projeto que previa a criação de 8 milhões de postos de trabalho no país em 4 anos:

Boris Casoy - É, o senhor fala em estelionato eleitoral de Lula se for eleito, mas o senhor também tem feito promessas extremamente...com muita força, por exemplo, 8 milhões de empregos. Será que são promessas alcançáveis?

Serra - É viável, Boris. Se você fizer a exportação crescer, e está acontecendo, trazer dólares, com isso você pode baixar os juros, você dá força para os setores, como educação, saúde, que empregam muita gente. É a exportação, agricultura familiar, agricultura irrigada, construção civil, turismo, que gera muitos empregos. Nós temos um estudo setorial mostrando que dado um certo crescimento da economia, nós podemos expandir muito emprego.

Nestes dois períodos, a questão da saúde, explorada largamente pela publicidade de Serra na televisão, foi também discutida na cobertura dos telejornais. Tanto na propaganda, como nos noticiários, a ênfase nas realizações de Serra enquanto Ministro da Saúde do governo FHC estiveram presentes. Portanto, o candidato tucano teve sucesso em levar para o Jornal Nacional e Jornal da Record o debate sobre o assunto saúde, largamente discutido em sua propaganda de televisão. 
No que tange ao exame dos assuntos restantes, quando os separo e faço os testes de correlação, a hipótese é rejeitada pelo critério da porcentagem de correlações com significância. Das 20 correlações efetuadas, todas foram positivas (com uma média de $+0,51$ ), porém nenhuma delas teve significância, o que levou a rejeição da hipótese de transferência das prioridades da agenda dos assuntos restantes da propaganda de Serra para cobertura eleitoral dos telejornais (ver TAB. 4.15). Ou seja, os noticiários apresentaram uma ordem própria desses assuntos especificamente, diferente da debatida pelo candidato Serra.

TABELA 4.15 - 20 correlações para a verificação da transferência das prioridades dos assuntos restantes da propaganda de Serra para a agenda dos assuntos restantes da cobertura eleitoral de Serra nos telejornais (Jornal Nacional e Jornal da Record) $1^{\circ}$. e $2^{\circ}$. turnos da eleição presidencial de 2002

\begin{tabular}{c|l|l|c|c}
\hline & \multicolumn{2}{|c|}{ Intervalos temporais de dias (time-lag) } & \multicolumn{1}{c}{ coeficiente } \\
\hline Correlações & Dias Propaganda Serra & Dias Cobertura Serra & r spearman & significância \\
\hline 1 & $20,22,24,27,29 / 08$ & $21,22,23,24,26,27,28,29,30,31 / 08$ & 0,35 & \\
2 & $22,24,27,29$ e 31/08 & $23,24,26,27,28,29,30,31 / 08,02$ e $03 / 09$ & 0,56 & \\
3 & $24,27,29,31 / 08,03$ e 05/09 & $26,27,28,29,30,31 / 08,02,03,04,05 / 09$ & 0,76 & \\
4 & 27,29 e 31/08, 03 e 05/09 & $28,29,30,31 / 08,02,03,04,05,06,07 / 09$ & 0,8 & \\
5 & 29 e 31/08, 03, 05, 07/09 & $30,31 / 08,02,03,04,05,06,07,09$ e $10 / 09$ & 0,45 & \\
6 & $31 / 08,03,05,07,10 / 09$ & $02,03,04,05,06,07,09,10,11$ e $12 / 09$ & 0,65 & \\
7 & $03,05,07,10,12 / 09$ & $04,05,06,07,09,10,11,12,13$ e $14 / 09$ & 0,23 & \\
8 & $05,07,10,12,14 / 09$ & $06,07,09,10,11,12,13,14,16$ e 17/09 & 0,45 & \\
9 & $07,10,12,14,17 / 09$ & $09,10,11,12,13,14,16,17,18$ e 19/09 & 0,34 & \\
10 & $10,12,14,17,19 / 09$ & $11,12,13,14,16,17,18,19,20$ e $21 / 09$ & 0,57 & \\
11 & $12,14,17,19,21 / 09$ & $13,14,16,17,18,19,20,21,23$ e 24/09 & 0,87 & \\
12 & $14,17,19,21,24 / 09$ & $16,17,18,19,20,21,23,24$ e 25, 26/09 & 0,59 & \\
13 & $17,19,21,24,26 / 09$ & $18,19,20,21,23,24,25,26,27$ e 28 /09 & 0,61 & \\
14 & $19,21,24,26,28 / 09$ & $20,21,23,24,25,26,27,28,30 / 09$ e $01 / 10$ & 0,35 & \\
15 & $21,24,26,28 / 09$ e $01 / 10$ & $23,24,25,26,27,28,30 / 09,01,03 / 10$ & 0,45 & \\
16 & $24,26,28,01,02 / 10$ & $25,26,27,28,30 / 09,01,03 / 10$ & 0,55 & \\
17 & $14,15,16,17,18 / 10$ & $15,16,17,18,19,21,22,23,24$ e $25 / 10$ & 0,12 & \\
18 & $15,16,17,18,19 / 10$ & $16,17,18,19,21,22,23,24,25$ e $26 / 10$ & 0,49 & \\
19 & $17,18,19,20,21 / 10$ & $18,19,21,22,23,24,25$ e $26 / 10$ & 0,54 & \\
20 & $18,19,20,21,22 / 10$ & $19,21,22,23,24,25$ e 26/10 & 0,59 & \\
\hline
\end{tabular}


Embora a hipótese de influência da agenda dos assuntos restantes da propaganda de Serra na cobertura dos telejornais tenha sido refutada, por não serem significativas as correlações, ao contrário do caso de Lula (ver TAB. 4.10 , p. 107), são todas positivas. Isso se deve ao fato de que uma boa parte do conteúdo da política negativa, propagada pelo tucano contra seus oponentes no horário eleitoral e nos comerciais instantâneos, ter conquistado as telas dos telejornais, sobretudo do Jornal da Record.

Em princípio, uma boa parte dos ataques realizados na propaganda de tevê pelo candidato tucano contra Ciro Gomes acabaram sendo transferidos para os noticiários. No Jornal Nacional foi relatada a notícia de que o Tribunal Superior Eleitoral (TSE) havia concedido liminar proibindo que Serra divulgasse, em seus programas, imagens de Fernando Collor, o qual era associado à imagem do candidato Ciro Gomes, da Frente Trabalhista. Embora a notícia tenha sido negativa para Serra, o telejornal colocou em pauta o ataque tucano. No Jornal da Record, Serra aparece atacando a administração de Ciro no estado do Ceará: "Quando ele foi governador do Ceará, a dengue atingiu o nível mais alto do Brasil e o cólera também, tanto que lá ele era chamado de 'governador do cólera' ".

No período entre 10 a 26 de setembro, os ataques contra Anthony Garotinho e Luiz Inácio Lula da Silva, desferidos nos programas eleitorais e anúncios de 30 e 60 segundos na televisão foram transferidos para a agenda da cobertura do Jornal da Record. Serra apareceu criticando o candidato do PSB, acusando-o de ter permitido "tanta liberdade para os bandidos na cadeia, inclusive a utilização de celulares para dirigir crime". Contra Lula, os ataques que se iniciaram ainda na primeira quinzena de setembro no horário eleitoral de televisão ganharam repercussão no telejornal da Record. O mesmo 
questionamento feito por Serra nos programas eleitorais de televisão, de que o candidato petista não mostrava como iria gerar os empregos prometidos, também foi veiculado na cobertura: "Eu jamais vou me voltar contra o Lula. O que eu quero é discutir com o Lula propostas dele de governo, e o Lula poderá debater comigo, mostrando como vai criar 10 milhões de empregos".

No segundo turno, os ataques de Serra contra Lula na propaganda de tevê ganharam não só a pauta do Jornal da Record, como também do Jornal Nacional - embora neste último caso de maneira bem inferior. Nos telejornais, a insistência de Serra para que Lula participasse de debates foi largamente veiculada: "O PT não tem escapado apenas do debate, pessoa a pessoa, tem escapado também da comparação. O que dá medo no Brasil é um candidato a presidente ter medo de debater". Serra também afirmou que o PT tinha "várias faces": "Existem três PTs: o PT da tevê, marketing, emoção, ect.; o PT do MST, que ontem, por exemplo, esse PT fez uma tropa de choque para perturbar a nossa presença no Rio de Janeiro; e tem o PT da administração, que nós conhecemos no Rio Grande do Sul, que levou o Rio Grande do Sul para trás". Serra conseguiu ainda transportar para os noticiários os seguintes ataques: a ameaça, expressa no horário eleitoral, de que Lula levaria o Brasil a uma crise econômica parecida com a da Argentina; o prenúncio de uma crise de governabilidade, como havia acontecido na Venezuela com Hugo Chávez, caso o candidato petista chegasse à presidência; além da questão sobre a contradição do discurso de Lula e do PT, que colocava em dúvida se a mudança prometida era para melhor ou para pior:

Olha pessoal, a gente tem que prestar atenção, é importante fazer mudança, mas mudança pra melhor. Quer dizer, não dá para você dizer para quem não tem nada, que você vai mudar tudo e, ao mesmo tempo, pra quem tem tudo, que você não vai mudar nada. Esse é o discurso hoje do PT. Pra elite, diz que não vai mudar nada; pro "povão", diz que vai mudar tudo. O mais provável é que caiamos numa dessas duas alternativas: ou a tremenda frustração depois das expectativas; ou então, jogar o país de volta à inflação. 
Em geral, os resultados sinalizam que as prioridades dos assuntos do candidato tucano foram reproduzidas na agenda dos assuntos da cobertura dos noticiários de tevê. Quando comparei somente as saliências da pauta substantiva da propaganda com a cobertura do candidato do PSDB nos telejornais a hipótese de transferência das saliências do conteúdo da propaganda para os noticiários foi validada. Mas quando considerei apenas os assuntos restantes, a hipótese foi refutada.

\section{Influência da cobertura do noticiário de Serra na propaganda de Serra}

A hipótese inversa, ou seja, da influência da cobertura eleitoral de Serra na propaganda tucana na televisão, foi rejeitada, quando considerei todos os assuntos, pois apenas $20,83 \%$ das correlações foram significantes (ver TAB. 4.16). Esse resultado sinaliza que não houve uma transferência das ênfases da cobertura da mídia da candidatura Serra para a propaganda do mesmo candidato, nos intervalos considerados. 
TABELA 4.16 - 24 correlações para a verificação da transferência das prioridades de todos assuntos da cobertura eleitoral de Serra nos telejornais (Jornal Nacional e Jornal da Record) para a agenda de todos os assuntos da propaganda de Serra na televisão - $1^{\circ}$. e $2^{\circ}$. turnos da eleição presidencial de 2002

\begin{tabular}{|c|c|c|c|c|}
\hline & \multicolumn{2}{|c|}{ Intervalos temporais de dias (time-lag) } & \multicolumn{2}{|l|}{ Coeficiente } \\
\hline Correlações & Dias Cobertura Serra & Dias Propaganda Serra & r spearman & significância \\
\hline 1 & $12,13,14,15,16$ e $17 / 08$ & 20,22 e $24 / 08$ & 0,56 & 0,05 \\
\hline 2 & $15,16,17,19,20$ e $21 / 08$ & 22,24 e $27 / 08$ & 0,67 & 0,01 \\
\hline 3 & $17,19,20,21,22$ e $23 / 08$ & 24,27 e $29 / 08$ & 0,44 & \\
\hline 4 & $20,21,22$ e 23,24 e $26 / 08$ & 27,29 e $31 / 08$ & 0,4 & \\
\hline 5 & $22,23,24,26,27$ e $28 / 08$ & $29,31 / 08$ e $03 / 09$ & 0,41 & \\
\hline 6 & $23,24,26,27,28,29 / 08$ & $31 / 08,03$ e 05/09 & 0,58 & 0,05 \\
\hline 7 & $27,28,29,30,31 / 08$ e $02 / 09$ & 03,05 e $07 / 09$ & 0,41 & \\
\hline 8 & $29,30,31 / 08$ e 02,03 e $04 / 09$ & 05,07 e 10/09 & 0,44 & \\
\hline 9 & $31 / 08,02,03,04,05$ e $06 / 09$ & $07,10,12 / 09$ & 0,16 & \\
\hline 10 & $03,04,05,06,07$ e 09/09 & 10,12 e $14 / 09$ & 0,01 & \\
\hline 11 & $05,06,07,09,10$ e $11 / 09$ & 12,14 e $17 / 09$ & 0,07 & \\
\hline 12 & $07,09,10,11,12,13 / 09$ & 14,17 e $19 / 09$ & 0,21 & \\
\hline 13 & $10,11,12,13,14,16 / 09$ & 17,19 e $21 / 09$ & 0,49 & \\
\hline 14 & $12,13,14,16,17$ e $18 / 09$ & 19,21 e $24 / 09$ & 0,41 & \\
\hline 15 & $14,16,17,18,19$ e $20 / 09$ & 21,24 e $26 / 09$ & 0,47 & \\
\hline 16 & $17,18,19,20,21$ e $23 / 09$ & 24,26 e $28 / 09$ & 0,28 & \\
\hline 17 & $19,20,21,23,24$ e $25 / 09$ & $26,28 / 09$ e $01 / 10$ & 0,48 & \\
\hline 18 & $21,23,24,25,26,27 / 09$ & $28 / 09,01$ e $03 / 10$ & 0,25 & \\
\hline 19 & $7,8,9,10,11$ e $12 / 10$ & 14,15 e $16 / 10$ & 0,05 & \\
\hline 20 & $8,9,10,11,12$ e $14 / 10$ & 15,16 e $17 / 10$ & 0,47 & \\
\hline 21 & $9,10,11,12,14,15 / 10$ & 16,17 e $18 / 10$ & 0,43 & \\
\hline 22 & $10,11,12,14,15$ e $16 / 10$ & 17,18 e $19 / 10$ & 0,5 & \\
\hline 23 & $11,12,14,15,16$ e $17 / 10$ & 18,19 e $21 / 10$ & 0,53 & 0,05 \\
\hline 24 & $12,14,15,16,17$ e $18 / 10$ & 19,21 e $22 / 10$ & 0,6 & 0,05 \\
\hline
\end{tabular}

No que diz respeito ao teste de correlações para essa associação apenas considerando a agenda de assuntos substantivos, verifica-se que somente $10 \%$ das correlações tiveram significância, embora todas as 20 correlações tenham sido positivas, com uma média de +0,36 (ver TAB. 4.17). Esse resultado leva-nos a refutar a hipótese de que a cobertura dos jornalistas nos noticiários conseguiu enviar suas prioridades para a pauta substantiva da propaganda de televisão de Serra. 
TABELA 4.17 - 20 correlações para a verificação da transferência das prioridades dos assuntos substantivos da cobertura de Serra nos telejornais (Jornal Nacional e Jornal da Record) para a agenda dos assuntos substantivos da propaganda eleitoral de Serra $1^{\circ}$. e $2^{\circ}$. turnos da eleição presidencial de 2002

\begin{tabular}{c|l|l|c|c}
\hline & \multicolumn{1}{|c|}{ Intervalos temporais de dias (time-lag) } & Coeficiente \\
\hline Correlações & Dias Cobertura Serra & Dias Propaganda Serra & r spearman & significância \\
\hline 1 & $8,9,10,12,13,14,15,16,17,18 / 08$ & $20,22,24,27$ e $29 / 08$ & 0,3 \\
2 & $10,12,13,14,15,16,17,19,20$ e $23 / 08$ & $22,24,27,29$ e $31 / 08$ & 0,56 & 0,39 \\
3 & $13,14,15,16,17,19,20,21,22$ e $23 / 08$ & $24,27,29,31 / 08$ e $03 / 09$ & 0,35 \\
4 & $15,16,17,19,20,21,22,23,24,27 / 08$ & $27,29,31 / 08,03$ e $05 / 09$ & 0,73 \\
5 & $17,19,20,21,22,23,24,27,28$ e $29 / 08$ & $29,31 / 08,03,05,07 / 09$ & 0,45 \\
6 & $20,21,22,23,24,26,27,28,29$ e $30 / 08$ & $31 / 08,03,05,07$ e $10 / 09$ & 0,24 \\
7 & $22,23,24,26,27,28,29,30,31 / 08$ e $02 / 09$ & $03,05,07,10$ e $12 / 09$ & 0,19 \\
8 & $24,26,27,28,29,30,31,02,03$ e $04 / 09$ & $05,07,10,12$ e $14 / 09$ & 0,18 \\
9 & $27,28,29,30,31,02,03,04,05$ e $06 / 09$ & $07,10,12,14$ e $17 / 09$ & 0,14 \\
10 & $29,30,31,02,03,04,05,06,07$ e $09 / 09$ & $10,12,14,17$ e $19 / 09$ & 0,32 \\
11 & $31,02,03,04,05,06,07,09,10$ e $11 / 09$ & $12,14,17,19$ e $21 / 09$ & 0,42 \\
12 & $03,04,05,06,07,09,10,11,12$ e $13 / 09$ & $14,17,19,21$ e $24 / 09$ & 0,33 \\
13 & $05,06,07,09,10,11,12,13,14$ e $16 / 09$ & $17,19,21,24$ e $26 / 09$ & 0,47 \\
14 & $07,09,10,11,12,13,14,16,17$ e $18 / 09$ & $19,21,24,26$ e $28 / 09$ & 0,39 \\
15 & $10,11,12,13,14,16,17,18,19$ e $20 / 09$ & $21,24,26,28 / 09$ e $01 / 10$ & 0,15 \\
16 & $01,02,03,04,05,07,09,10,11$ e $12 / 10$ & $14,15,16,17$ e $18 / 10$ & 0,45 \\
17 & $02,03,04,05,07,09,10,11,12$ e $14 / 10$ & $15,16,17,18$ e $19 / 10$ & 0,47 \\
18 & $03,04,05,07,09,10,11,12,14$ e $15 / 10$ & $16,17,18,19$ e $21 / 10$ & 0,38 \\
19 & $04,05,07,09,10,11,12,14,15$ e $16 / 10$ & $17,18,19,21$ e $22 / 10$ & 0,43 \\
20 & $05,07,09,10,11,12,14,15,16$ e $17 / 10$ & $18,19,21,22$ e $23 / 10$ & \\
\end{tabular}

\subsection{Conclusões}

Neste capítulo demonstrei que o PT teve uma influencia relativa na agenda de sua candidatura, apresentada no horário eleitoral e nos spots de televisão. Além disso, constatei que a agenda de Lula e a agenda de Serra influenciaram de alguma forma na elaboração da agenda dos noticiários Jornal Nacional e Jornal da Record.

Para tanto, o primeiro passo foi testar a hipótese de que o PT transferiu para a agenda da propaganda de seu candidato Luiz Inácio Lula da Silva, as prioridades de sua plataforma de governo. A hipótese foi corroborada, ou seja, os assuntos mais discutidos no programa de governo do partido foram também os mais enfatizados na agenda substantiva da propaganda de Lula. Esse resultado me levou a concluir que o partido foi importante para a definição da ordem das questões discutidas na propaganda de televisão. 
O segundo passo foi examinar em que medida a agenda da candidatura Lula e a de Serra, divulgadas nas propagandas de televisão, estava associada à agenda de suas respectivas coberturas nos telejornais. Constatei que essas duas agendas estão interligadas, pois a hierarquia de importância dos assuntos das agendas é semelhante. No entanto, observei que a associação entre a agenda dos candidatos e o conteúdo da cobertura dos telejornais existe apenas entre os assuntos substantivos ou sobre questões programáticas e não no conjunto dos assuntos de outra natureza.

Em seguida, analisei a influência da agenda da propaganda dos candidatos na agenda das coberturas dos noticiários e vice-versa. Constatei, mediante testes de correlações entre as ordens das agendas, levando em conta intervalos temporais, que tanto Lula como Serra conseguiram transferir para a pauta das coberturas dos telejornais as prioridades difundidas em suas respectivas propagandas. No entanto, essa transferência ocorreu de maneira dependente da natureza dos assuntos, uma vez que somente quando considerei os assuntos substantivos, ou sobre propostas de políticas públicas, é que houve correspondência entre as agendas dos candidatos e dos noticiários de televisão. Desse modo, conclui que tanto Lula como Serra foram capazes de influenciar a hierarquia da discussão da agenda mais substantiva da cobertura dos telejornais. Quanto à ordem dos assuntos não substantivos, os candidatos foram incapazes de influenciá-la, posto que, nesse caso, o destaque dos assuntos das coberturas foi determinado pelos noticiários de televisão e não pelos políticos.

Nos testes da hipótese para detectar a influência das coberturas na agenda das propagandas, observei que a cobertura dos noticiários foi incapaz de influenciar a agenda da propaganda de tevê dos candidatos, tanto na ocasião em que comparei todos os assuntos das agendas, como quando observei apenas os assuntos substantivos. 


\section{Considerações finais}

Os candidatos influenciam a elaboração da agenda da mídia em épocas eleitorais. São diversas as maneiras pelas quais isso ocorre, sendo as principais delas os "pseudo-eventos", aparições públicas, viagens, comícios, passeatas, discursos públicos, conferências de imprensa, releases destinados à divulgação nos meios de comunicação, soundbites e propaganda política de televisão. Nesta tese tratei de mostrar em que medida os candidatos conseguiram transferir para a cobertura dos telejornais a discussão feita em suas propagandas de televisão, além de investigar se o PT foi capaz de transferir para a agenda de sua candidatura na televisão, as prioridades dos assuntos debatidos em sua plataforma de governo. Tanto uma questão quanto outra foram negligenciadas até aqui pela bibliografia brasileira.

A idéia de que a agenda da mídia recebe a contribuição dos candidatos e de outros atores, como organizações, grupos sociais, etc., começou a ser concebida no início da década de 1980. A partir de então houve uma reelaboração do conceito da agenda-setting, que se limitava apenas à compreensão de que a mídia desempenhava a função de agendar o público. Assim sendo, os estudos sobre agenda-setting passaram a investigar a origem da agenda dos meios de comunicação em campanhas eleitorais, examinando em que medida os candidatos conseguiram transferir para a agenda da mídia a saliência dos assuntos discutidos em suas agendas.

Os estudos internacionais sobre a formação da agenda da mídia em campanhas demonstraram que os candidatos são hábeis em transferir para a agenda da mídia suas prioridades e fazer com que os meios de comunicação enfatizem as questões que eles desejam. Dessa maneira, a agenda dos candidatos tem se tornado, na visão de um conjunto de autores, uma variável indispensável para a análise da formação da agenda da mídia em épocas eleitorais (Semetko, Blumler, Gurevitch \& Weaver,1991; Lichter \& Smith, 1996; Miller, Andsager \& Riechert , 1998; Tedesco, 2001; McCombs, 2004). 
No Brasil, contudo, a hipótese de que os candidatos fossem um dos principais determinantes da elaboração da agenda da cobertura eleitoral dos telejornais não havia sido testada em nenhuma eleição brasileira e um dos meus objetivos neste trabalho foi fazê-lo na campanha presidencial de 2002. No estudo visei comprovar que as candidaturas foram capazes de agendar a pauta das questões veiculadas nos dois noticiários observados, Jornal Nacional e Jornal da Record, levando para o conteúdo dos telejornais as prioridades discutidas em suas propagandas de televisão. Outro objetivo foi provar que o PT influenciou a elaboração da agenda da propaganda de tevê de sua candidatura através de seu programa de governo, e nesse sentido, o partido deve ser incluído, pelo menos nesse caso, como uma variável que influenciou o agendamento da campanha na televisão, nesta eleição em particular.

Antes da realização dos testes das hipóteses do trabalho, no entanto, procurei demonstrar que a campanha na tevê não começou somente no início de julho de 2002, depois da definição oficial das candidaturas, mas sim desde o final de 2001, através da veiculação dos programas de televisão que os partidos têm direito por lei. Demonstrei também que os telejornais, Jornal Nacional e Jornal da Record, foram importantes para as candidaturas, já que deram um amplo espaço às coberturas dos candidatos durante o período que se estendeu do início de julho ao término do segundo turno da eleição presidencial, mas que a propaganda eleitoral de televisão, através do horário eleitoral e dos pequenos anúncios de 30 ou 60 segundos, foi o espaço primordial para os candidatos se comunicarem com os eleitores. Além disso ressaltei que a conjuntura sócio-econômica negativa e conseqüentemente a má avaliação do governo $\mathrm{FHC}$, registrada pelas pesquisas de opinião pública, favoreceu as candidaturas de oposição, maiormente a de Lula e prejudicou a de José Serra, que, diante da má avaliação da administração vigente, encontrou dificuldades de se assumir enquanto governo num cenário que exigia mudanças.

No capítulo 3, fiz uma avaliação geral do programa de governo do PT e de Serra e uma análise de conteúdo da propaganda de televisão de Lula e de 
Serra, bem como da cobertura dessas duas candidaturas nos telejornais, Jornal Nacional e Jornal da Record.

Quanto à discussão realizada nos programas de governo, observei primeiramente que na plataforma petista o debate predominante se fez em torno da questão da economia. Para o partido o principal alvo era fazer a economia crescer e gerar empregos, mas para que isso fosse possível era necessário romper com a política econômica do governo FHC e instaurar um novo modelo econômico de desenvolvimento. No programa de Serra verifiquei que a economia foi o assunto mais discutido e as principais propostas apresentadas foram de crescimento econômico e criação de empregos, que seriam alcançados mediante alguns ajustes na economia e investimento em setores que mais geram empregos, como infra-estrutura, educação, saúde, turismo e agricultura.

No que se referiu à propaganda, demonstrei que a de Lula e a de Serra tiveram em comum a discussão preponderante sobre as propostas de programa de governo. Mas, em relação aos assuntos restantes das duas agendas, observei que Lula deu mais ênfase aos apelos de esperança e de pátria, enquanto a de Serra, de modo distinto, realçou principalmente as qualidades pessoais e ataques contra os adversários. Ressaltei ainda que essa diferença de estratégia das duas candidaturas se deveu as suas posições nas pesquisas de intenção de voto.

Em relação aos noticiários de tevê, verifiquei que as coberturas de Lula e de Serra foram semelhantes. Tanto numa quanto noutra predominaram os assuntos sobre a campanha (agenda dos candidatos, estratégias e descrição de eventos) e pesquisas eleitorais, enquanto os assuntos substantivos, acerca de questões concretas e programáticas, apareceram de maneira limitada. Argumentei que o motivo dessa preferência pode ter ocorrido em virtude dos jornalistas levarem em conta os critérios de noticiabilidade que entendem que os assuntos acerca do andamento da campanha dos candidatos e pesquisas eleitorais são de maior interesse da audiência do que os assuntos a respeito de programas de governo. 
No capítulo 4, que se refere à parte central da tese, realizei os testes de hipóteses levantadas no estudo. Examinei com detalhe a relação entre a agenda dos candidatos Luiz Inácio Lula da Silva e de José Serra e o conteúdo da cobertura dessas candidaturas nos dois telejornais mais importantes do país, Jornal Nacional e Jornal da Record, na campanha presidencial de 2002 no Brasil, através da realização de testes de correlação.

Verifiquei, em primeiro lugar, a associação entre as agendas dos candidatos e a agenda das coberturas dos telejornais. A hipótese de associação entre as ordens dos assuntos da agenda da propaganda de Lula e as ordens dos assuntos da agenda da cobertura do candidato petista nos noticiários foi aceita somente quando considerei os assuntos substantivos, pois quando inclui todos os assuntos, ou na ocasião em que considerei apenas os assuntos restantes, a conjetura foi refutada. Já a hipótese de associação da agenda da propaganda tucana com a agenda dos noticiários televisivos sobre o candidato do PSDB foi corroborada quando considerei os assuntos substantivos e todos os assuntos, mas não quando comparei apenas os assuntos restantes.

A conclusão é a de que existe associação entre as agendas de Lula e a agenda da cobertura de Lula nos telejornais, bem como há associação entre a agenda de Serra e a agenda da cobertura de Serra nos noticiários, mas esta conexão se restringe à agenda de assuntos substantivos, de modo que os assuntos dessa natureza mais enfatizados pelas candidaturas em suas propagandas também foram os mais salientados em suas coberturas no Jornal Nacional e Jornal da Record. Quanto aos assuntos restantes, a hierarquia dos assuntos é distinta entre as agendas comparadas, pois enquanto o candidato petista realçou em sua propaganda apelos de esperança e de pátria, e Serra enfatizou suas qualidades pessoais e atacou seus adversários, as coberturas dos noticiários de Lula e de Serra discutiram mais as pesquisas eleitorais e o andamento da campanha das candidaturas (atividades dos candidatos, eventos, passeatas, palestras, etc.). 
Em seguida realizei os testes de hipóteses para a verificação da transferência das prioridades das agendas de Lula e de Serra para as agendas de suas respectivas coberturas nos noticiários de televisão, levando em conta intervalos temporais determinados. Averigüei que tanto o candidato petista como o tucano cumpriu a função de agenda-setting, ou seja, agendaram o noticiário do Jornal Nacional e Jornal da Record sobre suas respectivas candidaturas. Mas a hipótese de influência de Lula e de Serra na agenda de suas respectivas coberturas somente foi aceita quando analisei separadamente os assuntos substantivos das agendas.

É interessante notar que além dos candidatos ter conseguido transmitir a ordem de importância dos assuntos substantivos de suas propagandas para a cobertura dos telejornais, obtiveram êxito também em transferir a maneira como os assuntos foram discutidos nos noticiários. Por exemplo, Lula conseguiu transportar para a cobertura do Jornal Nacional e Jornal da Record suas propostas para a segurança, educação e principalmente a confirmação de que honraria os compromissos assumidos pelo governo federal e que manteria o controle da inflação. José Serra conseguiu deslocar para os telejornais sua discussão sobre a segurança, o relato de suas realizações na área da saúde, além de suas propostas de geração de empregos e de crescimento econômico. O candidato também conseguiu transferir para os noticiários grande parte dos ataques contra seus adversários.

Efetuei também o teste da hipótese inversa, de que a cobertura dos candidatos influenciou a agenda das propagandas de Lula e de Serra. A hipótese de que cobertura de Lula agendou a propaganda do candidato petista, bem como a de que o conteúdo do noticiário de Serra conseguiu transferir a prioridade de seu conteúdo para a propaganda tucana, foram refutadas, já que as correlações foram muito fracas. Dessa forma, as coberturas realizadas pelos telejornais não influenciaram a agenda da propaganda dos candidatos.

Em síntese, os achados sinalizaram que as propagandas de televisão das candidaturas Lula e Serra desempenharam a função de agenda-setting ou de agendamento na elaboração da agenda da cobertura dos telejornais, uma 
vez que a análise do cross-lagged correlations (ver QUADRO 1.5, p.32) indicou correlações mais altas na direção da influência do conteúdo da propaganda dos candidatos no conteúdo da cobertura dos noticiários do que o inverso. Esses resultados podem ser visualizados, de maneira resumida, nas figuras apresentadas abaixo.

FIGURA C.1 - Cross-lagged correlations - síntese dos resultados (Lula)

* Somente para assuntos substantivos

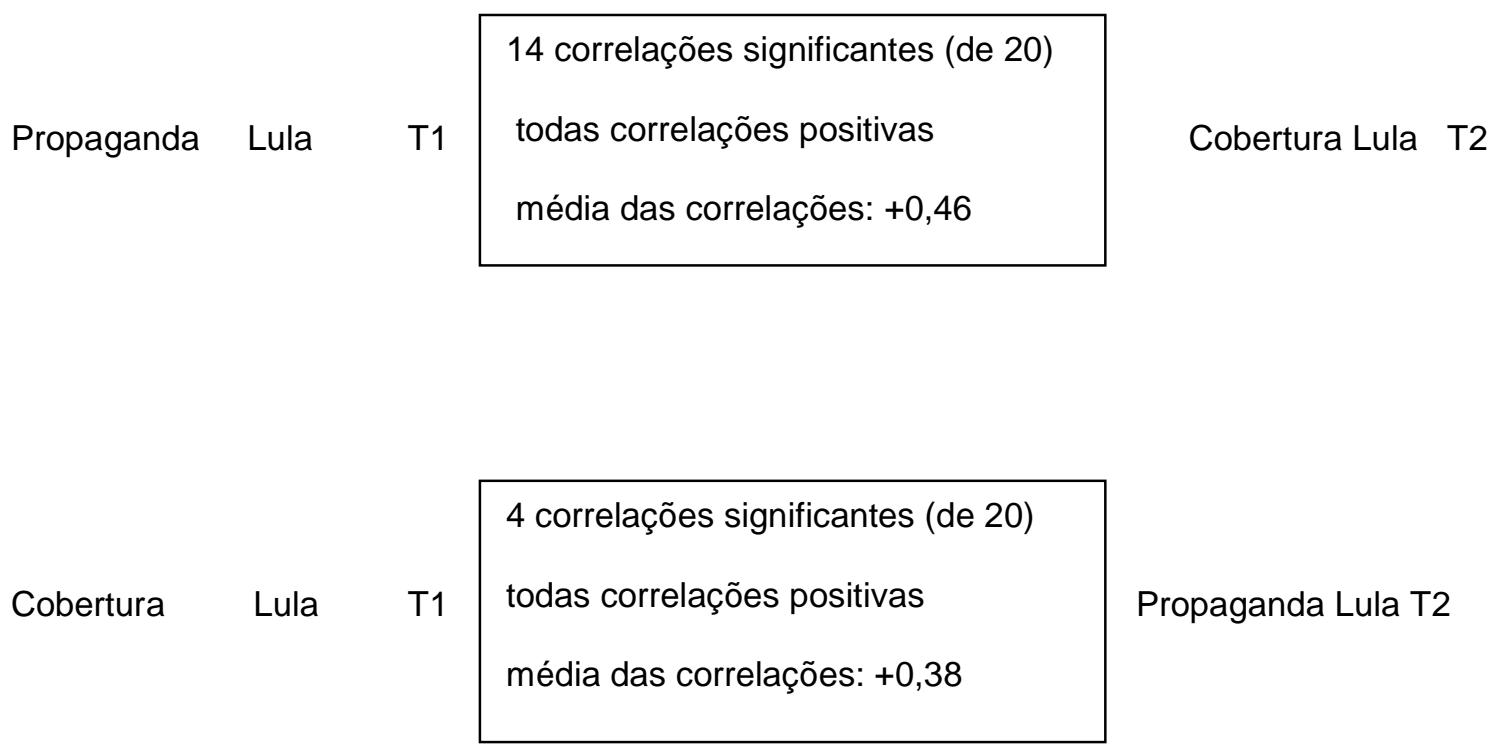

FIGURA C.2 - Cross-lagged correlations - síntese dos resultados (Serra)

*Somente para assuntos substantivos

\begin{tabular}{lc|l} 
Propaganda Serra T1 & $\begin{array}{l}15 \text { correlações significantes (de 20) } \\
\text { todas correlações positivas } \\
\text { média das correlações: }+0,55\end{array}$ \\
\hline
\end{tabular}

Cobertura Serra T2 
\begin{tabular}{ll|l} 
Cobertura Serra $\quad$ T1 & $\begin{array}{l}2 \text { correlações significantes (de 20) } \\
\text { todas correlações positivas } \\
\text { média das correlações: }+0,36\end{array}$
\end{tabular}

No capítulo 4 também realizei o teste entre a agenda do PT e a agenda do candidato Lula, mediante o confronto do programa de governo petista, lançado em março de 2002, com a propaganda do candidato do PT veiculada na televisão durante o primeiro e segundo turnos da eleição presidencial, entre 20 de agosto a 25 de outubro de 2002. Limitei-me somente à verificação da influência do programa do PT na propaganda de seu candidato, porque no caso do PSDB o exame da influência partidária através da plataforma foi inviável, posto que o programa de governo não passou pela discussão partidária, sendo formulado no âmbito de equipe de campanha do próprio candidato e direcionado para a divulgação na propaganda de tevê.

A hipótese de influência da agenda do programa de governo do PT na agenda da propaganda de Lula confirmou-se, pois houve correspondência entre a ordem dos assuntos destas duas agendas. Ou seja, tanto a pauta da plataforma partidária como da propaganda deram mais prioridade para a economia, "social em geral" e assuntos específicos da área social, como educação, fome, segurança e saúde, e menos importância aos assuntos como meio-ambiente, assuntos estrangeiros, Forças Armadas, cidades e regiões brasileiras. Assim sendo, o PT foi capaz de transferir para a agenda de seu candidato a ênfases dada aos assuntos em sua plataforma.

Antes de terminar, gostaria de apontar, de modo geral, a contribuição que acredito que este trabalho tenha dado aos estudos de mídia e política no 
país. Uma primeira contribuição foi mostrar, ao contrário da tese largamente defendida até então pelos estudos do CR-P de que os telejornais influenciam a pauta dos candidatos, que foram os candidatos que agendaram a cobertura dos noticiários e não o oposto, pelo menos na campanha presidencial de 2002. Ou seja, a cobertura dos noticiários apenas transmitiu uma agenda préestabelecida pelos políticos. Uma outra contribuição deste estudo foi mostrar que o PT se distinguiu do PSDB quanto à capacidade de influência no conteúdo da propaganda de televisão de seus respectivos candidatos, Lula e Serra, na eleição de 2002. Contrariamente ao PSDB, que não teve nenhuma influência na pauta discutida por seu candidato, posto que nesse caso o programa de governo foi construído no âmbito do candidato e de sua equipe de campanha, o PT, que participou da formulação do programa de governo para a campanha, conseguiu transferir para a pauta de seu candidato, o conteúdo da plataforma partidária, tendo assim uma importância relativa para a agenda discutida por Lula durante o período eleitoral.

É preciso enfatizar, porém, que sendo a análise presente de apenas uma eleição específica, não posso generalizar os achados desta pesquisa para campanhas presidenciais precedentes. Desse modo, este trabalho não esgotou a compreensão da formação da agenda das campanhas presidenciais brasileiras de nosso multipartidarismo atual. O estudo em tela só poderá completar-se com futuras investigações. Ainda assim entendo que o esboço presente tenha sido indispensável para a tarefa do desenvolvimento dos estudos da agenda-setting no Brasil. 


\section{Bibliografia}

ALBUQUERQUE, Afonso de. A Campanha Presidencial no Jornal Nacional: Observações Preliminares. In: Comunicação \& Política, Rio de Janeiro, 1 (1): 23-40, agosto/novembro de 1994.

. O Horário Gratuito de Propaganda Eleitoral e os Spots Políticos. Particularidades do Áudio Visual Político Brasileiro. In $A$ Encenação dos Sentidos - Mídia e Cultura, org. José Luiz Braga; Sergil Dayrell Porto e Antônio Fausto Neto, ed. Diadorim, RJ, 1995.

- O Horário Gratuito Político de Propaganda Eleitoral e os Spots Políticos. Particularidades do Áudio Visual Político Brasileiro. In: A Encenação dos Sentidos - Mídia e Cultura. RJ: ed. Diadorim, 1996a.

- A Batalha pela Presidência: o horário de propaganda eleitoral na campanha de 1989. Rio de Janeiro, 1996b (tese de doutoramento).

ALDÉ, Alessandra. As Eleições Presidenciais de 2002 nos Jornais. Trabalho apresentado no III Encontro (Inter) Nacional de Estudos de Comunicação e Política, realizado de 11 a 13 de dezembro de 2002 na Faculdade de Comunicação da UFBa.

ASP, Kent. The Struggle for the Agenda - Party Agenda, Media Agenda and Voter Agenda in the 1979 Swedish Election Campaign, Communication Research, Vol. 10: 333-55, 1983.

AZEVEDO, Fernando. Imprensa e Cobertura Eleitoral no Pleito Municipal de 2000 em São Paulo, XXIII Encontro Anual da ANPOCS, Caxambu, 19-23 de outubro, 2001.

. Imprensa, Campanha Presidencial e Agenda da

Mídia, in Antônio Canelas Rubim (org.), Mídia e Eleições 98, Salvador, Edições FACOM, pp. 31-56, 2000.

BARBER, J. Race for the presidency. Englewood Cliffs, NJ: Prentice-hall, 1978.

BECKER, L., MCCOMBS, Maxwell e MCLEOD, J. The Development of Political Cognitions, in Chaffee (ed.), Political Communication, Sage, Beverly Hills, 1975, pp. 21-64.

BERELSON, Bernard. Content Analysis in Communication Research. 1. ed. New York: Hafner Press, 1952. 
BERKMAN, R. e KITCH, L. W. Politics in the media age. New York: McGraw Hill, 1986.

BLUMLER, J. G. e GUREVITCH, M. Towards a Comparative Framework for Political Communication Research. In: Political Communication, London, U.K. and Beverly Hills, S. H. Chaflflee (ed.) CA: Sage.p.165-193, 1975.

BOURDIEU, Pierre. Sobre a Televisão, Rio de Janeiro, Jorge Zahar Editor, 1997.

BOORSTIN, Daniel. The Image: A Guide To Pseudo-Events. New York: Atheneum, 1961.

BUCHANAN, Bruce I. Mediated Electoral Democracy: Campaigns, Incentives, and Reform, In Lance Bennett and Robert M. Entman, Mediated Politics Communication in the Future Democracy, 2001, p. $362-379$.

BUCHANAN, Bruce I. Electing a President: The Markle Comission Research on Campaig '88. Austin, Tx: University of Texas Press, 1991.

CAMPBELL, Angus. Elections and the Political Order, New York, Wiley, 1966.

CAREY, J. How Shape Campaigns. In: Journal of Communication, vol. 26, pp. $50-57,1976$.

CARREIRÃO, Yan de Souza. A Decisão do Voto nas Eleições Presidenciais no Brasil (1989 a 1998): a importância do voto por avaliação de desempenho. São Paulo, Tese de doutorado, datilo, 2000.

CHAIA, Vera. O Telejornalismo Local das Eleições Municipais de São Paulo", trabalho apresentado na ABCP, Rio de Janeiro, 2002.

COHEN, Bernard C. The Press and Foreign Policy, Princeton University Press, Princeton, 1963.

COLLING, Leandro. O Enquadramento do Jornal Nacional (JN) na Cobertura Sobre a Crise Econômica", manuscrito, 1999.

CONVERSE, Philip E. The Nature of Belief Systems in Mass Publics, In: Apter, David (org.). Ideology and Discontent. New York, Free Press of Glencoe, 1964.

DOWNS, Antony. Uma Teoria Econômica da Democracia. São Paulo, Edusp, 1999.

EYAL, C. ; WINTER, J. e DE GEORGE, W. The Concept of Time Frame in Agenda-Setting", in Wilhoit G. (ed.), Mass Communication Review Yearbook, vol. 2. Sage, Beverly Hills, p. 212-217, 1981.

ENTMAN, Robert. Framing: Toward Clarification of a Fractured Paradigm. In the Journal of Communication, vol. 43, n.4, autumn, 1993. 
FAUSTO NETO, Antônio. Entre os Cruzamentos de Sentidos. In Fausto Neto e Eliseo Verón (orgs.), Lula Presidente - Televisão e Política na Campanha Eleitoral, UNISINOS, 2003, p.65-83.

. Inclusões e Apagamentos. In Fausto Neto e Eliseo

Verón (orgs.), Lula Presidente - Televisão e Política na Campanha Eleitoral, UNISINOS, 2003, p. 85-117.

O Corpo entre Capturas e Fugas Enunciativas. In Fausto Neto e Eliseo Verón (orgs.), Lula Presidente - Televisão e Política na Campanha Eleitoral, UNISINOS, 2003, p. 147-174.

FIGUEIREDO, Rosali. Um Estudo de Caso sobre o Noticiário da Campanha Presidencial de 1994. Dissertação de Mestrado, São Carlos, 1997.

FIGUEIREDO, Marcus et al. Estratégia de Persuasão em Eleições Majoritárias: Uma Proposta Metodológica para o Estudo da Propaganda Eleitoral. RJ, IUPERJ, Série 100 Estudos, 1998.

FIGUEIREDO, Marcus \& ALDÉ, Alessandra. Intenção de Voto e Propaganda Política: Efeitos e Gramáticas da Propaganda Eleitoral - notas para um debate. Texto apresentado no $12^{\circ}$. Encontro Anual da Compôs, Universidade Federal de Pernambuco (ufpe), Recife, 03 e 06 de junho de 2002.

GITLIN, T. The whole World Is Watching. Berkeley, Ca.: University of California Press, 1980.

GRABER, D. A. Mass media and American Politics. GRABER, D. A. (ed.), Washington, DC: Congressional Quarterly Press, 1980.

HALLIN, Daniel C. Sound Bite News: Television Coverage of Elections, 1968 1988, in Journal of Communication, Spring 1992/ vol. 42 n. 2, pp. 5-24.

IYENGAR, Shanto e KINDER, Donald. News that Matters. Chicago e Londres: The University of Chicago Press, 1987.

JAMIESON, K. H. Dirty Politics: Deception, Distraction and Democracy. New York and Oxford: Oxford University Press, 1993.

JAMIESON, K. H. e WALDMAN, P. The press Effect - Politicians, Journalists and the Stories That Shape the Political World, New York, Oxford University Press, 2003.

JOHNSON-CARTEE, Karen e COPELAND, Gary. Inside Political Campaigns Theory and Pratice. Westport, Connecticut, London, 1997a.

. Manipulation of the American Voter - Political Campaign Commercials, Westport, Connecticut London, 1997b. 
JORGE, V. L. Os Meios de Comunicação de Massa nas Campanhas. Comunicação \& Política, v. 4, n.1, p.126-133, 1994.

KERBEL, Matthew Robert. Edited for Television /CNN, ABC, and the 1992 Presidential Campaign, Colorado \& Oxford, Westview Press, 1994.

LAZARSFELD, Paul. Radio and Printed Page. An Introduction to the Study of Radio and Its Role in the Communication of Ideas, Duell, Sloane and Pearce, New York, 1940.

LEFF, D. R., PROTESS, D. L. e BROOKS, S. C. Cruzading Journalism: Changing Public Attitudes and Policy-Making Agenda, Public Quarterly, vol. 50, 1986.

LICHTER, S. R. e SMITH, T. Why Elections Are Bad News: Media and Candidate Discourse in the 1996 Presidential Primaries, Press/Politics, 1, 4 (1996), pp. 15-35.

LIMA, Venício A. Televisão e Política: Hipótese sobre o $1^{\circ}$. Turno da Eleição Presidencial de 1989, In Comunicação e Política, Ano 9, n. 11, abril-julho; p. 29-54, 1990. 1994a.

. O Enredo Eleitoral: Televisão e Poder - A Hipótese do Cenário de Representação Política, in Comunicação e Política, vol. 1, n. 1,

. Propaganda Política no Rádio e na Televisão. In Mídia, Eleições e Democracia, MATOS, Heloiza (org.), São Paulo, Scritta, p.191-205, 1994b.

LIMA, Venício e GUAZINA, L. Política Eleitoral na TV: Um Estudo Comparado do Jornal Nacional e do Jornal da Record em 1998. Relatório Preliminar: maiojunho, apresentação $22^{\circ}$. Encontro Anual da ANPOCS, outubro de 1998.

LIPPMANN, W. Public Opinion. New York, Free Press Paperbacks, 1997.

LIPSET, Seymour M. O Homem Político. Rio de Janeiro, Zahar, 1967.

LOURENÇO, Luiz Cláudio. Debates Presidenciais 2002: O Impacto das Disputas Televisivas. Artigo apresentado no $28^{\circ}$. Encontro Anual da ANPOCS, 26 a 30 de outubro, Caxambu, MG, 2004.

. O Jogo Eleitoral na Televisão: Estratégias Persuasivas Usadas no HGPE de 1998 ao Governo de São Paulo, Universidade Federal de São Carlos, dissertação de mestrado, datilo, 2000.

MACIEL, Evelin e FABRÍCIO, Gustavo. A Identificação dos Formadores do CRP no Jornal Nacional da Rede Globo,manuscrito, 1995.

MCCOMBS, Maxwell. Setting the Agenda - the Mass Media and Public Opinion, Cambridge, Polity Press, 2004. 
MCCOMBS, Maxwell; SHAW, Donald. The Agenda-Setting Function of Mass Media, Public Opinion Quarterly, Vol. 36, pp. 176-185, 1972.

MANCINI, Paolo \& SWANSON, David. Politics, Media and Modern Democracy: An International Study in Electoral Campaigning and their Consequences. Westport: Praeger, 1996.

MIGUEL, Felipe. Mídia e Eleições: a Campanha de 1998 na Rede Globo", Dados, vol. 42, no. 2, p. 253-276, 1999.

A Eleição Visível: A Rede Globo Descobre a Política em 2002. Dados v. 46 n. 2, Rio de Janeiro, 2003.

MILLER, Mark; ANDSAGER, Julie e RIECHERT, Bonnie. Framing the Candidates in Presidential Primaries', Journalism \& Mass Communication Quarterly, 75 (1998), pp. 312-24.

MUNGHAM, Geoff. A Batalha pelo Controle da Agenda: a Mídia, os Políticos e o Processo Eleitoral na Grã-Bretanha, Comunicação \& Política, n.s., v.3, n.2, pp.30-45, 1997.

NIMMO, D. The Political Persuaders: the Techniques of Modern Elections Campaigns. Democracies Englewood Cliffts, NJ: Prentice-Hall, 1970.

PANKE, Luciana, "As Mudanças nos Discursos de Lula Sob o Prisma da Temática Emprego", tese de doutorado defendida na Escola de Comunicação da USP, 2005.

PATTERSON, Thomas. The mass media election: How Americans choose their president. New York: Praeger, 1980.

. Out of Order. New York: Vintage Books, 1994.

PORTO, Mauro. A Televisão e o Primeiro Turno das Eleições Presidenciais de 2002: Análise do Jornal Nacional e do Horário Eleitoral. In Rubim (org.), Eleições Presidenciais em 2002 no Brasil - ensaios sobre mídia, cultura e política, Hacker editores, 2004, pp.68-90.

A Mídia Brasileira e a Eleição Presidencial de 2000 nos EUA: A Cobertura do Jornal Folha de S. Paulo. In Cadernos do Ceam, As Relações entre Mídia e Política, N. 6, Universidade de Brasília, 2001.

- Telenovelas e Política: o CR-P da eleição presidencial de 1994, in Comunicação \& Política, Ano I, n. 3, abril-julho de 1995.

RANNEY, Austin. Channels of Power - The Impact of Television on American Politics, Publishers New York, Basic Books, Inc., 1983.

ROBINSON, M. J. The Media in 1980: Was the Message the Message? In A. Ranney (ed.), The american elections of 1980 (pp. 171-211). Washington, DC: American Enterprise Institute, 1981. 
ROGERS, Everett M. \& DEARING, J. W. (1988). Agenda-Setting Research: Where Has It Been? Where IS It Going? In J. A. Anderson (Ed.). Communication Yearbook 11. Newbury Park, C. A. : Sage.

RUBIM, Antônio Albino Canelas \& AZEVEDO, Fernando Antônio. Mídia e Política no Brasil: Textos e Agenda de Pesquisa, in Lua Nova - Revista de Cultura e Política, No. 43, p. 189 -216, 1998.

SEMETKO, Holli e CANEL, Maria J. Agenda-Senders versus Agenda-Setter: Television in Spain' s 1996 Election Campaign. In Political Communication , v. 14, p. 93-109, 1997.

SEMETKO, H. A.; BLUMLER, J. G.; GUREVITCH, M. e WEAVER, D. H. The Formation of Campaign agendas: a Comparative Analysis of Party and Media Roles in Recent American and British Elections. Hillsdale, NJ: Lawrence Earlbaum, 1991.

SHAW, E. Agenda-Setting and Mass Communication Theory, Gazette (International Journal for Mass Communication Studies), vol. XXV, no. 2, pp. 96-105, 1979.

SHOEMAKER, Pamela e REESE, Stephen. Mediating the Message: Theories of Influences on Mass Media Content, New York; Longman, 1991.

SIGAL, Leon. Reporters and Officials, Lexington: Heath, 1973.

SINGER, André (1999). Esquerda e Direita no Eleitorado Brasileiro, São Paulo, Edusp, 1999.

SILVA, Paulo Sérgio da. HGPE e as Estratégias de Campanha na Eleição Presidencial de 1998. Dissertação de mestrado, Universidade Federal de São Carlos, 2000, datilo.

. A Cobertura do Jornal Nacional no Primeiro Turno da Eleição Presidencial de 2002, texto apresentado no Workshop "Partidos e Representação Política", Departamento de Ciência Política da Universidade de São Paulo, 21 de agosto de 2003, datilo.

SQUIRRA, S. Boris Casoy - O Âncora no Telejornalismo Brasileiro. Petrópolis, Vozes, 1993.

SCHWARTZ, T. The Responsive Chord. Garden City, NY: Anchor, 1972.

. The Inside of the Outside. In R. Agranoff (ed.), The News Style in Election Campaigns (pp. 344-358). Boston: Holbrook, 1976.

TEDESCO, John. Issues and Strategy Agenda-Setting in the 2000 Presidential Primaries, unpublished paper, Virginia Technological University, 2001.

TICHENOR, P. J. Agenda-setting: Media as Political Kingmakers? In: Journalism Quartely, 59 (3), p. 488-490, 1982. 
TRAQUINA, Nelson. O Estudo do Jornalismo no Século XX, RS, Ed. Unisinos, 2001.

TRENT, Judith S. e FRIEDENBERG, Robert V. Political Campaign Communication - Principles and Pratices. Third Edition, Connecticut London, Westport, 1995.

TUCHMAN, Gaye. Making News: A Study in the Construction if Reality. New York: Free Press, 1978.

WEAVER, D. H. ; GRABER, D. ; MCCOMBS, M. E. e EYAL, C. Media AgendaSetting in a Presidential Election: Issues, Imagens, Interest. New York; Praeger, 1981.

WILLIAMS, W., Jr. ; SHAPIRO, M. e CUTBIRTH, C. The Impact of Campaign Agendas on Perceptions of Issues. In David L. Protess and Maxwell McCombs (eds.), Agenda-setting: Readings on media, public opinion, and policy making (pp. 251-259). Hillsdale, N.J: Lawrence Erlbaum, 1991.

WINTER, James \& EYAL, Chaim. Agenda Setting for the Civil Rights Issue, Public Opinion Quarterly, 45 (1981), pp. 376-83.

WOLF, M. Teorias da Comunicação, Lisboa, Editorial Presença, 1999. 


\section{ANEXOS}

\section{Entrevista}

Orjan Olsen - Ipsos Opinion. 21-05-2004.

\section{Revistas e Jornais}

Veja, 13 de março de 2002.

Veja, 22 de maio de 2002, p. 42-46.

Veja, 23 de outubro de 2002, p. 42-44.

Folha de São Paulo, 21 de março de 2002.

Folha de São Paulo, 22 de agosto de 2002.

Folha de São Paulo, 13 de outubro de 2002.

Folha de São Paulo, 15 de outubro de 2002.

Folha de São Paulo, 23 de outubro de 2002.

Época, 28 de outubro de 2002.

\section{Documentos}

"Concepção e Diretrizes do Programa de Governo do PT para o Brasil", março de 2002, disponível em <www.//pt.org.br >.

"Programa de Governo: Coligação Lula Presidente", julho de 2002, disponível em

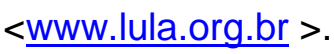

"Carta ao Povo Brasileiro", 22 de junho de 2002, disponível em < www.lula.org.br>.

"Compromisso com a Soberania, o Emprego e a Segurança do Povo Brasileiro", 23 de julho de 2002, disponível em < www.lula.org.br $>$.

"Trabalho e Progresso Para Todos", agosto de 2002, disponível em <www.joseserra.org.br>. 


\section{Siglas partidárias}

PC do B - Partido Comunista do Brasil

PCB - Partido Comunista Brasileiro

PDT - Partido Democrático Trabalhista

PFL - Partido da Frente Liberal

PGT - Partido Geral dos Trabalhadores

PL - Partido Liberal

PMDB - Partido do Movimento Democrático Brasileiro

PMN - Partido da Mobilização Nacional

PPB - Partido Progressista Brasileiro

PPS - Partido Popular Socialista

PSB - Partido Socialista Brasileiro

PSDB - Partido da Social Democracia Brasileira

PT - Partido dos Trabalhadores

PTB - Parido Trabalhista Brasileiro

PTC - Partido Trabalhista Cristão

PSTU - Partido Socialista dos Trabalhadores Unificados

PCO - Partido da Causa Operária 


\title{
Lista de variáveis e categorias
}

\author{
V1 - Temas específicos \\ V2 - Assuntos \\ Categorias: \\ economia \\ social em geral \\ educação \\ fome \\ saúde \\ infra-estrutura \\ cultura/ lazer/ etnias \\ segurança \\ regiões brasileiras \\ meio-ambiente \\ assuntos estrangeiros \\ cidades \\ Forças Armadas \\ campanha \\ pesquisas eleitorais \\ qualidades pessoais \\ esperança \\ ataques \\ mudança \\ pátria \\ outros
}

V3 - Data

V4 - Tempo (tempo em segundos dos temas) - somente para os bancos da propaganda de televisão e telejornais

V5 - Menções (freqüência de aparições dos temas específicos) - somente para o banco dos programas de governo

V6 - Categorias dos assuntos 
Assuntos substantivos (economia, social em geral, educação, fome, saúde, infra-estrutura, cultura/lazer/etnias, segurança, regiões brasileiras, cidades, meio-ambiente, assuntos estrangeiros e Forças Armadas);

assuntos restantes (campanha, pesquisas eleitorais, qualidades pessoais, esperança, ataques, mudança e pátria);

outros

V 7 - Candidaturas (Qual candidatura?) - somente para o banco da propaganda de televisão e telejornais

1. Lula

2. Serra

3. ambas

V 8 - Autor dos programas de governo (somente para o banco dos programas de governo)

1. PT

2. Serra

V 9 - Veículos (Qual veículo?)

1. Propaganda de televisão

2. Telejornais

3. Programa de governo

V 10 - Telejornais (Qual telejornal?)

$1 \mathrm{JN}$

$2 \mathrm{JR}$ 
GRÁFICO A. 1 - Média de audiência do Jornal Nacional e Jornal da Record na Grande São Paulo

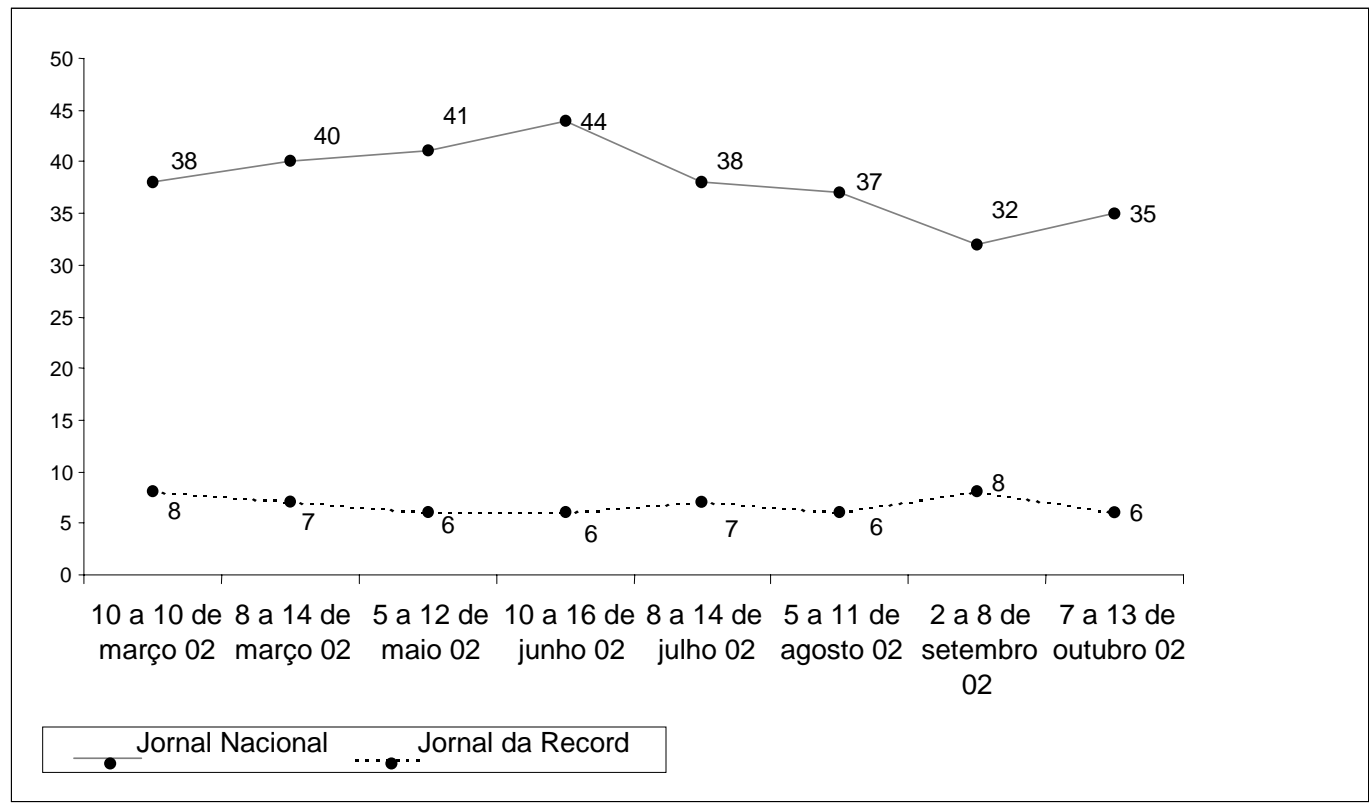

Fonte: IBOPE/ Folha de S. Paulo. 